\title{
Quantity and Quality of Base Flow and Stormwater Runoff in Independence, Missouri--October 1991 to February 1993
}

By GREGG K. SCHALK

U.S. GEOLOGICAL SURVEY

Open-File Report 93-495 


\title{
U.S. DEPARTMENT OF THE INTERIOR
}

\section{BRUCE BABBITT, Secretary}

\author{
U.S. GEOLOGICAL SURVEY
}

Gordon P. Eaton, Director

For additional information

write to:

District Chief

U.S. Geological Survey

1400 Independence Road

Mail Stop 200

Rolla, Missouri 65401

\section{Copies of this report may}

be purchased from:

\author{
U.S. Geological Survey \\ Earth Science Information Center \\ Open-File Reports Section \\ Box 25286, MS 517 \\ Federal Center \\ Denver, Colorado 80225
}




\section{CONTENTS}

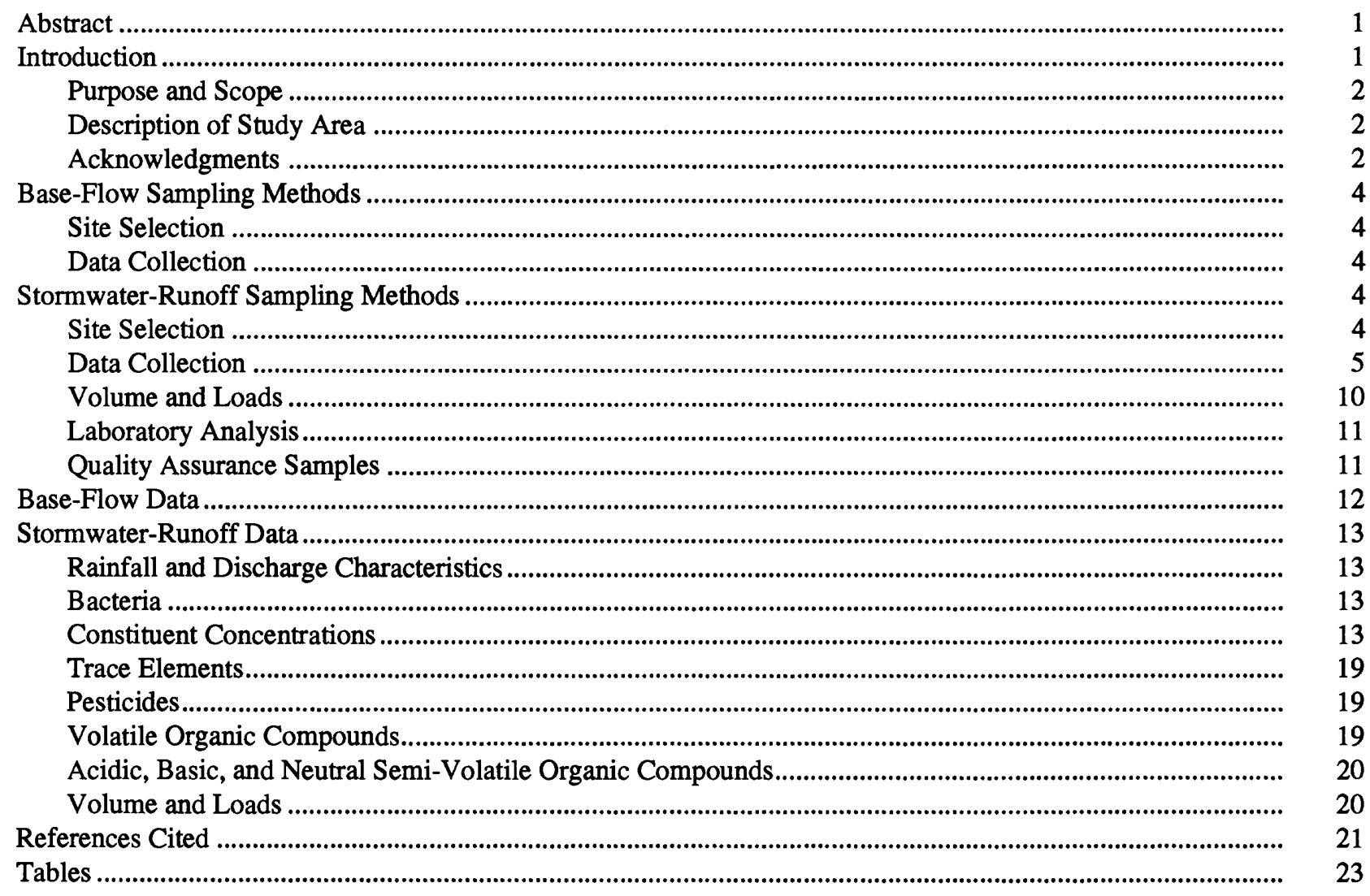

\section{FIGURES}

1. Map showing location of study area, study sites, and rain gages .................................................................. 3

2. Map showing location of base-flow sampling sites........................................................................................... 6

3-7. Rainfall intensities and discharge hydrographs for each storm event sampled at

3. Site 1

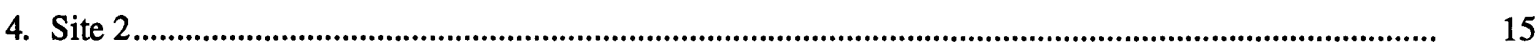

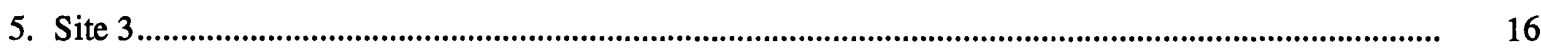

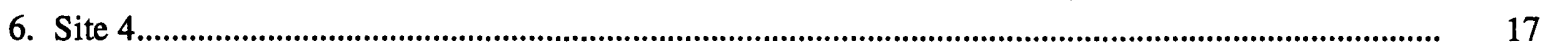

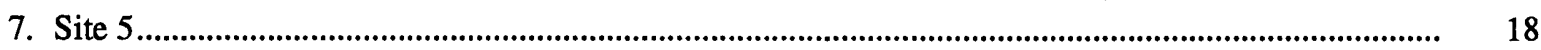


1. Selected data for study sites and drainage basins and location of rain gages.

2. Methods, detection limits, preservations, and bottle types used for determination of constituent concentrations at the U.S. Geological Survey, Arvada, Colorado.

3. Methods, detection limits, preservations, and bottle types used for determination of constituent concentrations at the Enseco Rocky Mountain Analytical Laboratory, Arvada, Colorado

4. Values of selected physical properties and constituent concentrations in stormwater-runoff replicate samples from sites 2 and 4 .

5. Concentration and percent recovery of pesticides in matrix spiked sample sets from site 1 , September 2, 1992.

6. Concentration and percent recovery of pesticides in matrix spiked sample sets from site 1 , February 11, 1993

7. Concentration and percent recovery of acidic, basic, and neutral semi-volatile organic compounds in matrix spiked sample sets from site 3, August 18, 1992

8. Concentration and percent recovery of volatile organic compounds in matrix spiked sample sets from site 2, December 9, 1992.

9. Statistical summary of physical properties and constituent concentrations in water samples collected at base-flow sampling sites in October 1991 and January to February 1992.

10. Values of selected physical properties and constituent concentrations of water samples collected during base-flow conditions.

11. Rainfall and discharge characteristics for three storms at each of the stormwater-runoff sampling sites

12. Values of selected physical properties and constituent concentrations from first-flush samples collected at the stormwater-runoff sampling sites

13. Values of selected physical properties and constituent concentrations in flow-weighted composite samples at the stormwater-runoff sampling sites

14. Concentrations of trace elements in flow-weighted-composite samples at the stormwaterrunoff sampling sites.

15. Concentrations of pesticides in flow-weighted-composite samples at the stormwater-runoff sampling sites.

16. Concentrations of volatile organic compounds in flow-weighted-composite samples at the stormwater-runoff sampling sites

17. Concentrations of acidic, basic, and neutral semi-volatile organic compounds in flow-weightedcomposite samples at the stormwater-runoff sampling sites

18. Stormwater-runoff volume and constituent loads at site 1

19. Stormwater-runoff volume and constituent loads at site 2

20. Stormwater-runoff volume and constituent loads at site 3

21. Stormwater-runoff volume and constituent loads at site 4

22. Stormwater-runoff volume and constituent loads at site 5 


\section{CONVERSION FACTORS}

\section{Multiply}

inch

foot

acre

cubic foot per second

pound, avoirdupois

cubic foot

square mile
By

25.4

0.3048

0.4047

0.02832

0.4536

0.02832

2.589
To obtaln

millimeter

meter

hectare

cubic meter per second

kilogram

cubic meter

square kilometer

Temperature in degrees Celsius $\left({ }^{\circ} \mathrm{C}\right)$ can be converted to degrees Fahrenheit $\left({ }^{\circ} \mathrm{F}\right)$ as follows:

$$
{ }^{\circ} \mathrm{F}=\left(1.8 \mathrm{x}^{\circ} \mathrm{C}\right)+32
$$




\title{
Quantity and Quality Of Base Flow and Stormwater Runoff in Independence, Missouri--October 1991 to February 1993
}

\author{
By Gregg K. Schalk
}

\section{Abstract}

Samples were collected in October 1991 and January to February 1992 at 193 sampling sites to characterize base flow in Independence, Missouri. From all samples collected at the base-flow sampling sites, 5 samples exceeded a pH of 9.0, total chlorine was detected in 45 samples, total detergents were detected in 1 sample, and total copper and total phenols were not detected in any samples.

Samples were collected from July 1992 to February 1993 at five stormwater-runoff sampling sites draining single-family, multifamily, commercial, and light-industrial land uses. Fecal coliform ranged from $\mathbf{5 0 0}$ to 290,000 colonies per 100 milliliters and fecal streptococci ranged from 1,900 to 500,000 colonies per 100 milliliters in 35 first-flush samples collected from 15 storms at the 5 sampling sites. The fecal coliform to fecal streptococci ratio averaged 0.9 and ranged from 0.01 to 4.1 .

At each stormwater-runoff sampling site, three flow-weighted composite samples were collected and analyzed for physical properties, common constituents, trace elements, pesticides, volatile organic compounds, and acidic, basic, and neutral semi-volatile organic compounds. Runoff loads were calculated for each constituent detected. The chemical oxygen demand ranged from 36 to 1,600 milligrams per liter. Biochemical oxygen demand ranged from 15 to greater than 650 milligrams per liter. Dissolved solids concentrations ranged from 34 milligrams per liter at a commercial site to 14,700 milligrams per liter at a light-industrial site that had large unsheltered piles of road salt. For all sites suspended solid concentrations ranged from 38 to 1,200 milligrams per liter.

Antimony, beryllium, selenium, and thallium were not detected, and silver was detected once. Mercury was detected with concentrations of $0.1,0.2$, and 0.3 microgram per liter. The following ranges of trace element concentrations (micrograms per liter) were detected: arsenic (1 to 10), cadmium (less than 1 to 40), chromium (less than 1 to 99), copper (8 to 130), lead (20 to 800), nickel (3 to 37 ), and zinc (110 to 6,200$)$.

Pesticides detected include chlordane, $p, p^{\prime}$-DDD, $p, p^{\prime}$-DDT, diazinon, dieldrin, lindane, and Aroclor 1254. Thirteen of the 63 volatile organic compounds analyzed were detected 27 times with concentrations ranging from 0.2 to 5.1 micrograms per liter. Acidic, basic, and neutral semi-volatile organic compounds detected include di-2-ethylhexyl phthalate, fluoranthene, phenanthrene, and pyrene.

\section{INTRODUCTION}

During 1990 the U.S. Environmental Protection Agency (USEPA) mandated that all cities with a population of 100,000 or greater be required to submit a stormwater discharge permit application under the National Pollution Discharge Elimination System (NPDES) program. The purpose of the permit is to establish an approach to 
control pollutants in stormwater (U.S. Environmental Protection Agency, 1990). The permit application requires characterization of water discharges to the municipal storm sewer system. The U.S. Geological Survey (USGS), in cooperation with the city of Independence, Missouri, began a study in July 1991 to:

1. Characterize the quantity and quality of water discharging (base flow) from selected conveyances within the city limits of Independence during dry-weather periods.

2. Characterize the quantity and quality of stormwater runoff from five selected homogenous land-use basins in Independence.

\section{Purpose and Scope}

The purpose of this report is to document site descriptions, data collection techniques, and laboratory analytical methods and to present the water quantity and quality results collected from base-flow sampling from October 1991 to February 1992 and from stormwater runoff from July 1992 to February 1993.

The scope of this report includes measurements of discharge, specific conductance, $\mathrm{pH}$, and water temperature and concentrations of total chlorine, total copper, total detergent, and total phenols from 226 samples collected at 193 sites preceding 72 hours of dry weather. This report also includes results from stormwater runoff analyzed for bacteria, physical properties, common constituents, trace elements, pesticides, volatile organic compounds, and semi-volatile acidic, basic, and neutral methylene chloride extractable organic compounds (hereafter referred to in this report as acidic, basic, and neutral organic compounds) from 15 storm samples from 5 urban land-use sites. Stormwater runoff volume and loads were calculated for each storm at each site. Volume and loads were simulated using data from this report and methods described by Driver and Tasker (1990).

\section{Description of Study Area}

The city of Independence (fig. 1) is located in the west-central part of Missouri and lies on the eastern side of the Kansas City metropolitan area adjacent to the eastern city limits of Kansas City, Missouri. During 1990 the population of Independence was 112,301 (City of Independence, 1993).

Independence occupies about $78 \mathrm{mi}^{2}$ (square miles) and is primarily a suburban community with commercial areas developed along the arterial streets. Independence is composed of 59 percent urban land and 41 percent non-urban land (agricultural and undeveloped land). Of the urban land 61 percent is single-family residential, 6.1 percent is commercial, and 2.4 percent is multi-family residential. The only heavy industrial area is limited to the Lake City Army Ammunition Plant, which is 12.6 percent of the urban land use. Light industrial land uses cover 1.9 percent of the urban land use, and a vacant-surface, industrial underground site covers 2.2 percent of urban land use. The remaining 14 percent of the urban land use includes public facilities, municipal waste facilities, and golf courses.

The average annual precipitation for the area is 35.2 in. (inches; National Oceanic and Atmospheric Administration, 1991). Of the annual precipitation, an average of $24.4 \mathrm{in.} \mathrm{occurs} \mathrm{during} \mathrm{April} \mathrm{through}$ September. The mean minimum January temperature in the study area is $17.2^{\circ} \mathrm{F}$ (degrees Fahrenheit), and the mean daily maximum July temperature is $88.5^{\circ} \mathrm{F}$. The 24-hour, 2-year recurrence-interval rainfall is $3.5 \mathrm{in}$. (Hershfield, 1961).

All of the larger streams in Independence drain north into the Missouri River. These larger streams include Fire Prairie Creek, Little Blue River, Mill Creek, Rock Creek, and Sugar Creek (fig. 1). The Little Blue River and its tributaries drain about twothirds of the city. The tributary streams of the Little Blue River that drain Independence include Adair Creek, Bundschu Creek, Burr Oak Creek, Crackerneck Creek, East Fork Little Blue River, and Spring Branch Creek (fig. 1). Ditches, gutters, curbs, swales, and ephemeral stream tributaries drain a major part of the developed area to the perennial streams. Subterranean storm sewers drain newly developed areas, main arterial roads, and densely populated areas.

\section{Acknowiedgments}

The author expresses appreciation to Dick Champion, director of the Independence Water 

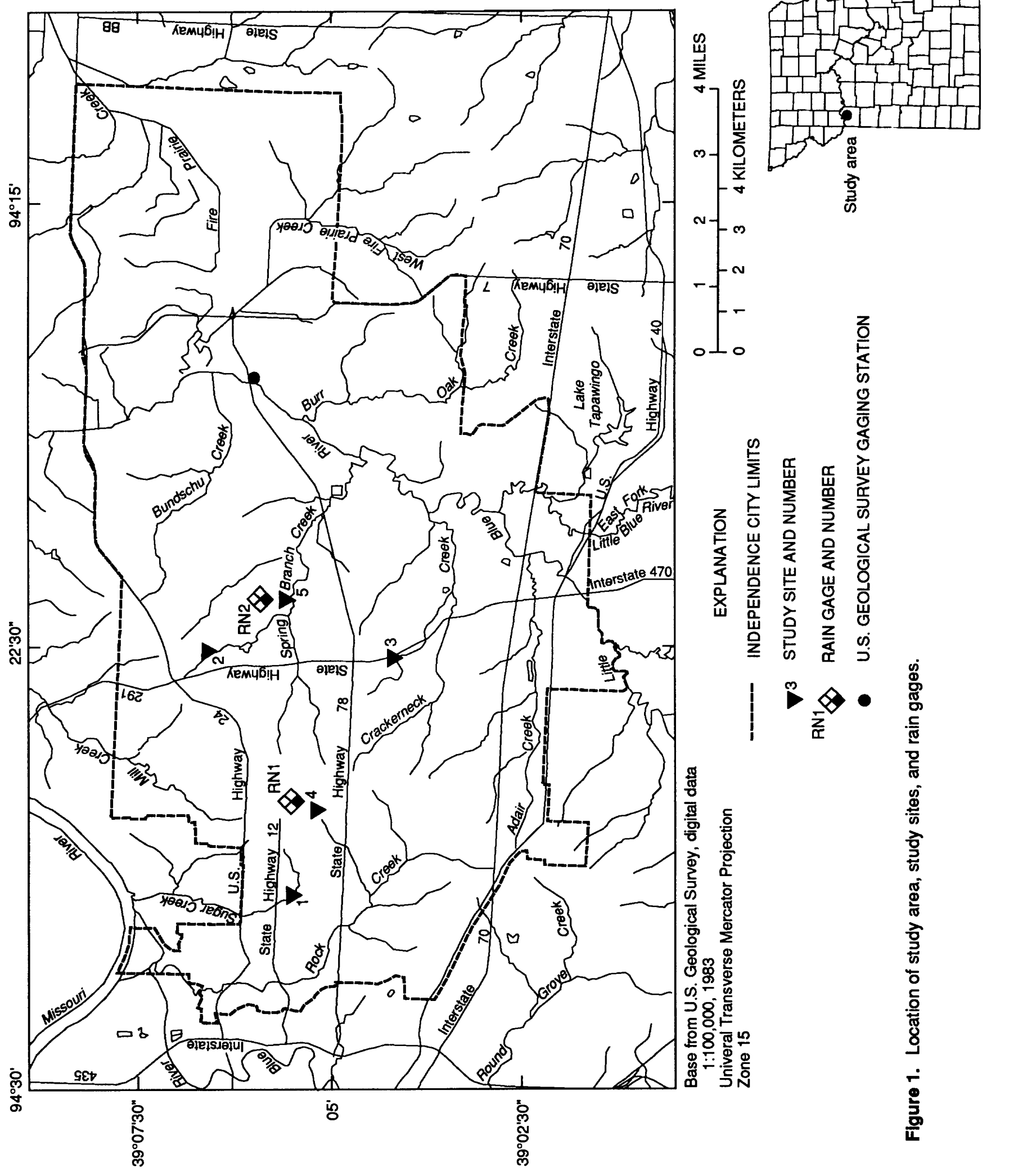
Pollution Control Department; Steve Spydell, Independence Water Pollution Control Department; personnel from the Independence Water Pollution Control Sewer Maintenance Department for assistance in construction of the sampling site; and Jane Henry, Independence Water Pollution Control Laboratory for the coordination of the biochemical oxygen demand analysis. University of Missouri 4-H extension center, Independence, and private citizens allowed data collection equipment on their property.

\section{BASE-FLOW SAMPLING METHODS}

To determine quantity of water discharging and selected constituent concentrations during base flow (referred to by the USEPA as dry-weather screening) into the streams of Independence, samples were collected in all basins. These samples were collected after 72 hours of no precipitation to ensure that water sampled was not from stormwater runoff.

\section{Site Selection}

Because perennial streams and other openchannel conveyances drain most of Independence, a systematic procedure was developed to locate sampling sites based on these drainage characteristics. This procedure identified sites in conveyances with base flow. Sample sites were selected at the farthest downstream point in each stream basin that had a cross section adequate for a discharge measurement. Site selection continued upstream until no flow was present. Upstream sample sites were located at flowing outfalls, upstream from flowing outfalls, at the mouth of flowing tributaries, upstream from flowing tributaries, and at selected sites along the stream. Baseflow sampling sites were established at 193 points in the city limits of Independence (fig. 2).

\section{Data Collection}

Discharge and water-quality data were collected at the 193 samples sites (fig. 2). Discharge, specific conductance, $\mathrm{pH}$, water temperature, and concentrations of total chlorine, total copper, total detergents, and total phenols were measured either onsite or within 48 hours of sample collection. Discharge was measured using either volumetric methods or by a pygmy current meter (Rantz and others, 1982). Specific conductance was measured within 48 hours after sample collection at the USGS in Independence with a meter calibrated in the range encompassing the water sample and reported in microsiemens per centimeter at $25{ }^{\circ} \mathrm{C}$ (degrees Celsius). The $\mathrm{pH}$ of the water was measured at the time of collection with an electronic meter calibrated in the $\mathrm{pH}$ range of 4.0 to 10.0. Water temperature was measured at the time of collection using a mercury thermometer and reported to the nearest $0.5{ }^{\circ} \mathrm{C}$.

Concentrations of total chlorine, total copper, total detergents, and total phenols were measured using colorimetric reagents and methods developed by the Hach Company ${ }^{1}$. Total chlorine concentrations were determined at the time of collection. Concentrations of total copper, total detergents, and total phenols were determined at the USGS in Independence within 48 hours from the time of sample collection. The Hach methods are considered semiquantitative because no quality assurance samples were collected to verify the precision and accuracy of the analytical methods.

\section{STORMWATER-RUNOFF SAMPLING METHODS}

To determine the quantity and quality of stormwater runoff, discharge and rainfall depths were measured and water-quality and quality assurance samples were collected and analyzed. Constituent loads were computed for each constituent detected. The data collected for this study are stored in the USGS National Water Data Storage and Retrieval System (WATSTORE).

\section{Site Selection}

Sites 1 to 5 (fig. 1) were selected for the purpose of monitoring water quantity and quality from stormwater runoff from specific land uses

\footnotetext{
${ }^{1}$ Use of trade or firm names in this report is for identification purposes only and does not constitute endorsement by the U.S. Geological Survey.
} 
within Independence (table 1, at the back of this report). Site 1 is downstream from a single-family housing area, site 2 from a multi-family housing area, sites 3 and 4 from commercial areas, and site 5 from a light industrial area. Selection of each study site was based on homogenous land use, suitable hydrologic controls for a reliable stage to discharge rating, and accessibility and safety.

Drainage and impervious areas for the study sites were computed from the topographic planning maps on file with the city of Independence and site visits. Land-use percentages were computed using a geographical information system data base of land-use coverages compiled by Independence and visits for sites 1 to 4 . Site 5 land-use data were computed using topographic planning maps and site visits.

Site 1 (fig. 1) is downstream from a fully developed single-family housing area. The basin drains 86 percent single-family housing, 4 percent commercial, 4 percent multi-family housing, 3 percent light industrial, and 3 percent public facilities. The approximate population density in the basin is 3,810 persons per square mile (City of Independence, 1993). Street gutters, ditches, and natural open channels are the primary conveyances that drain this basin. The stage to discharge relation is controlled by a culvert at high flow and by the stream channel at low flow.

Site 2 (fig. 1) is downstream from a multifamily housing area. This basin primarily has residential dwellings consisting of apartments and duplexes. The basin drains 69 percent single and multi-family housing, 17 percent commercial, and 14 percent vacant land. The population density in the basin is approximately 5,062 persons per square mile (City of Independence, 1993). Street gutters and underground storm sewers are the primary conveyances that drain this basin. The stage to discharge relation is controlled by a culvert at high flow and by the stream channel at low flow.

Site 3 (fig. 1) is downstream from a commercial area. This basin has various types of commercial facilities, including a large retail store, two strip malls, several restaurants, convenience stores, a car wash, and a storage facility. State Highway 291 crosses the basin. The basin drains 62 percent commercial land use, 24 percent singlefamily housing, 9 percent multi-family housing, and 5 percent public facilities. The population density in the basin is approximately 2,324 persons per square mile (City of Independence, 1993). Gutters and underground storm sewers are the main conveyances that drain the area. The stage to discharge relation is controlled by a culvert at high flow and by the stream channel at low flow.

Site 4 is downstream from the downtown commercial area of Independence. The basin drains approximately 53 percent single-family housing, 24 percent commercial, 16 percent public facilities, 5 percent light industry, and 2 percent multi-family housing. The population density in the basin is approximately 3,739 persons per square mile (City of Independence, 1993). Gutters and underground storm sewers are the main conveyances that drain the area. The stage to discharge relation is controlled by a culvert at high flow and by the stream channel at low flow.

Site 5 is downstream from a light industrial area. The basin drains 71 percent light industry, 22 percent vacant ground, and 7 percent salt-pile storage area for road deicing. No residential housing exists in this basin. Overland flow, gutters, and underground storm sewers are the main conveyances that drain the area. For this site, the stage to discharge relation control is a manmade grass-lined channel.

\section{Data Collection}

Continuous-streamflow records at the five stormwater-runoff sampling sites were collected with a float and stilling-well combination (Buchanan and Somers, 1978). Continuous stream stage was recorded in 5-minute increments. Stage also was collected manually while sampling stormwater runoff. Stage data were collected at $0.01-\mathrm{ft}$ (foot) increments. Stream stage was related to current-meter streamflow measurements (Buchanan and Somers, 1976) and to indirect measurement computations (Benson and Dalrymple, 1967) to prepare stage-discharge ratings (Kennedy, 1983). Indirect measurement computations for culverts (Bodhaine, 1976) were made at sites 1,2,3, and 4. Indirect measurement computations using the slope-area method (Dalrymple and Benson, 1967) were made at site 5. 

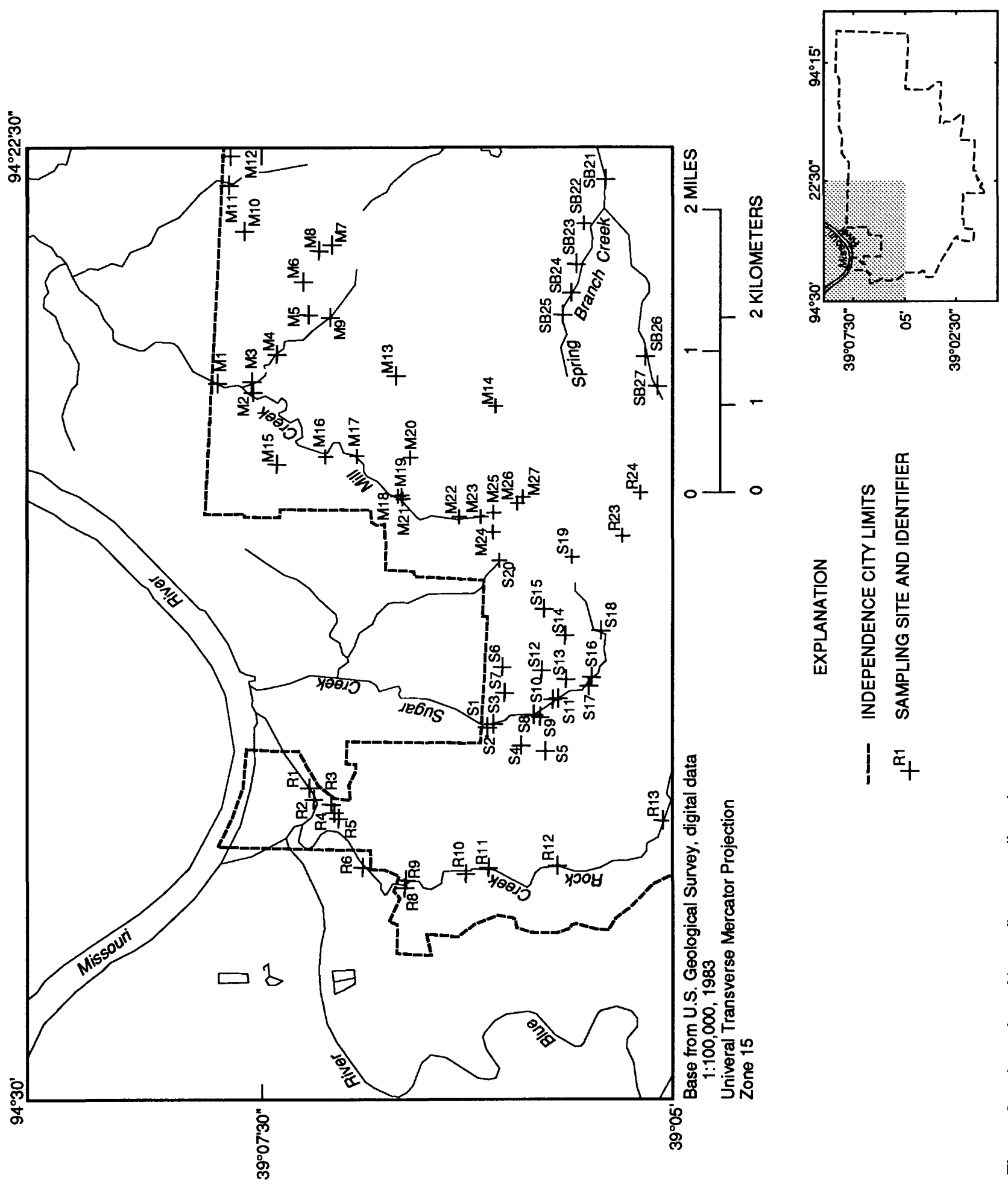

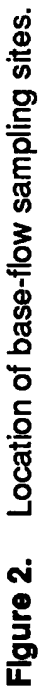




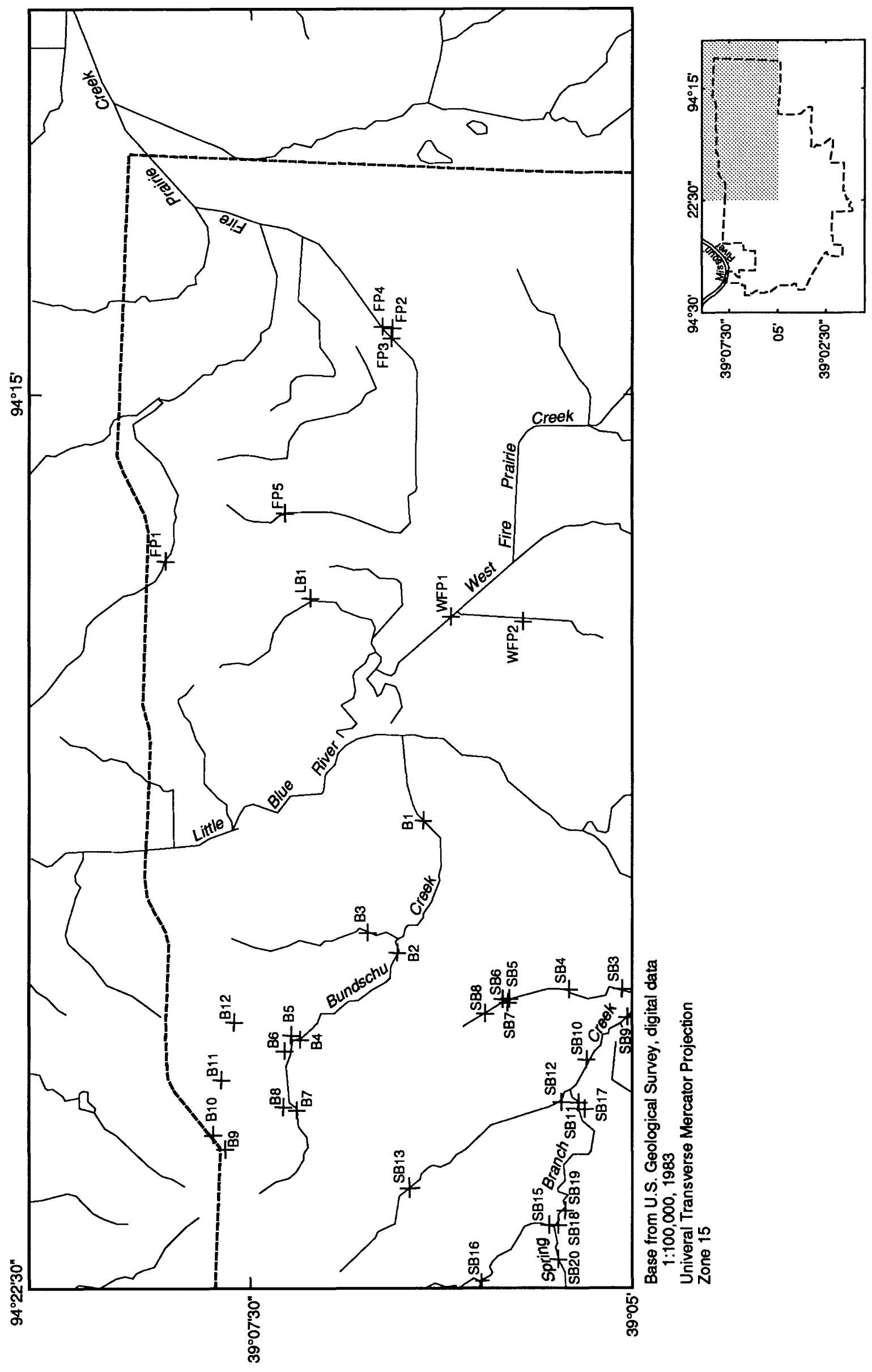

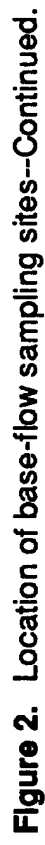




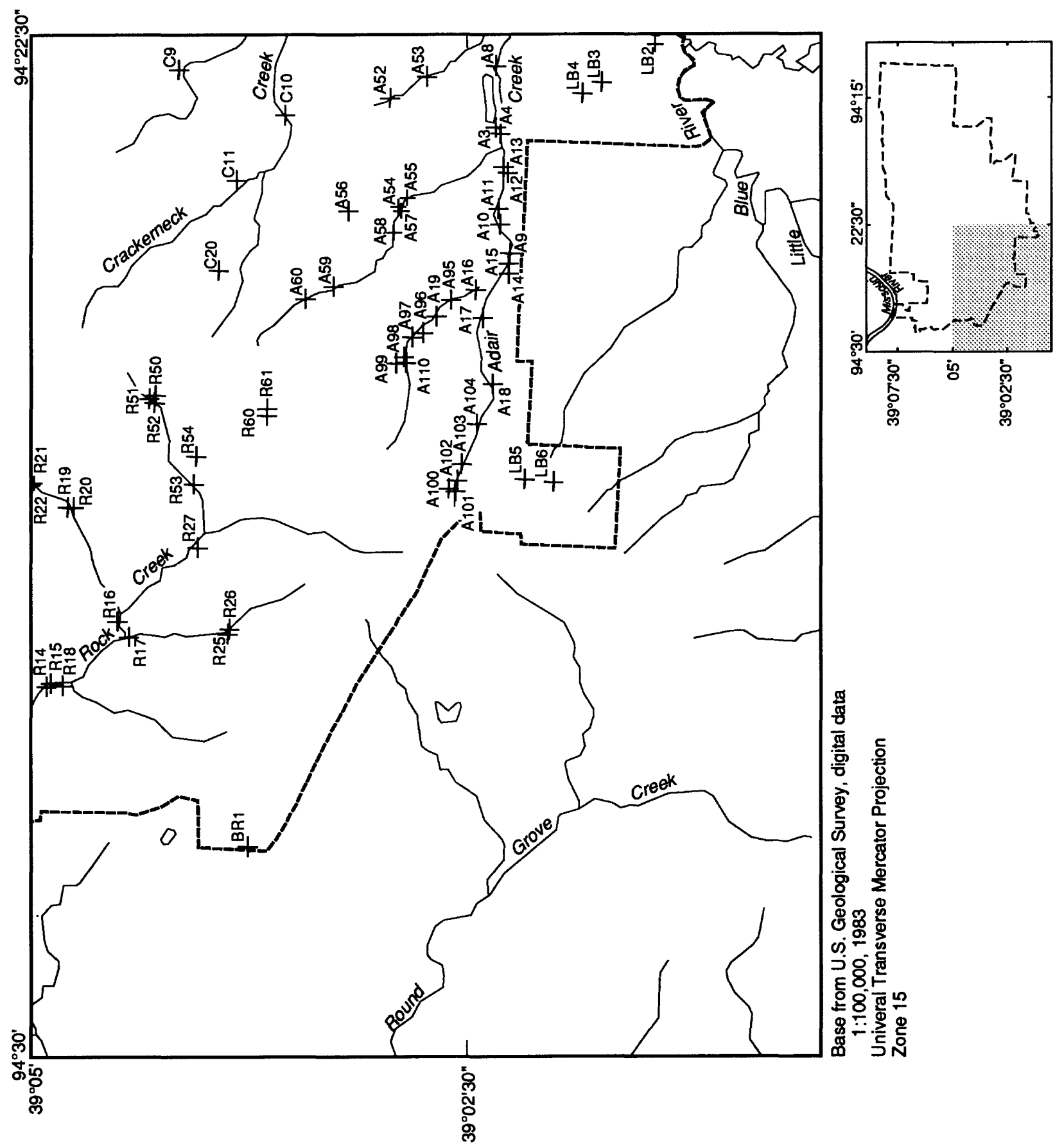

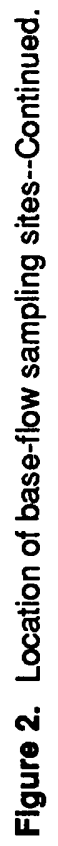




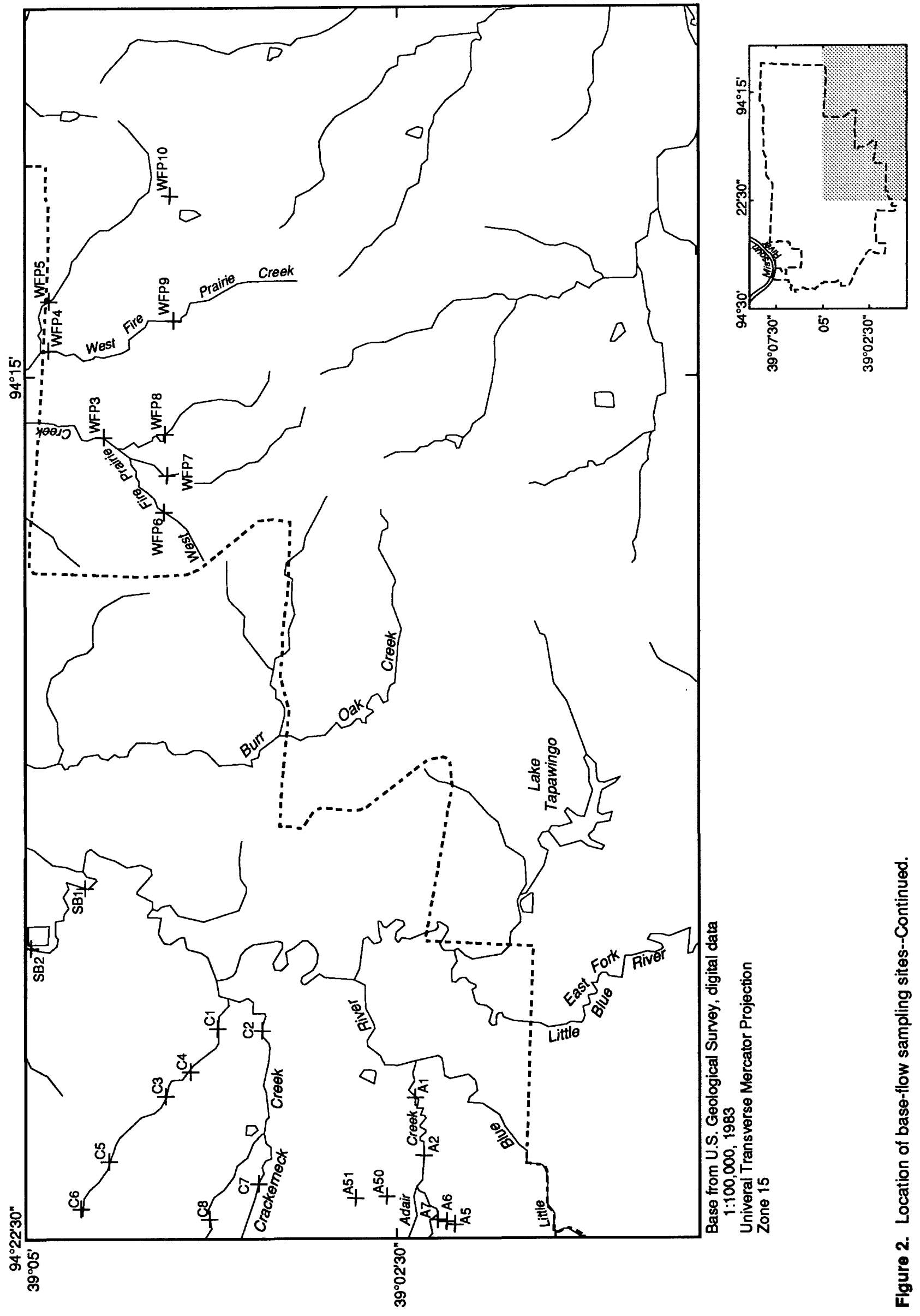


Continuous rainfall data were collected at two USGS sites, RN1 and RN2 (fig. 1). Rainfall datacollection sites were chosen to represent depths of rainfall at the sampling sites (table 1). Criteria for selecting rain gage locations included geographical location and overhead clearance above rain gage. The instrumentation for a rain gage included a 5minute-interval analog data recorder connected to a float inside a rainfall collection pipe. Rainfall data were collected at 0.01 -in. increments.

Stormwater runoff was sampled at least 72 hours after the previous storm of $0.1 \mathrm{in}$. or more of rain. Samples were either collected at one location in the stream or at several locations across the stream at equal width increments. Stormwaterrunoff samples were collected using a hand-held bottle.

Stormwater-runoff samples for physical properties, inorganic compounds, and organic compounds were of two types. Within the first 30 minutes of runoff, samples were collected for bacteria, total chlorine, cyanide, phenols, and oil and grease in the approved bottle (tables 2 and 3, at the back of this report; the sample for bacteria analysis was collected in a sterilized polyethylene bottle). Collectively, these samples are classified as the first-flush sample. Within the first 30 minutes and also throughout the duration of the runoff, a discrete sample was collected for a flowweighted-composite sample. The discrete sample was collected directly into a 1-gal (gallon) narrowmouth brown glass bottle for analyses of all constituents except volatile organic compounds. The discrete sample for volatile organic compound analysis was collected in a $40-\mathrm{mL}$ (milliliter) brown septum-capped bottle. To compute the volume of each discrete sample to be included in the flow-weighted-composite sample, the following method used was based on the midinterval method of subdividing described by Porterfield (1977) and adjusted to account for variable time intervals:

$$
v(n)=\frac{q(n)}{Q} \times V(t)
$$

where $v(n)$ is the volume of discrete sample to be added to the composite sample;

$q(n)$ is the total volume of discharge that occurred from one-half the time since the previous sample until onehalf the time to the next sample. The first sample volume is computed from the beginning of the stormwater runoff to one-half the time to the second sample. The last sample volume is computed from one-half the time since the previous sample to the end of the stormwater runoff;

$Q$ is total volume of stormwater runoff; and

$V(t)$ is total composite volume required.

The 1-gal discrete samples were composited at the USGS, Independence, within 24 hours of collection to obtain the flow-weighted composite sample. This sample was split into subsamples using a cone splitter and a churn splitter for the different preservation and analytical methods. The cone splitter was used to initially split the composite sample into 10 subsamples within a 3 percent equal volume and suspended sediment concentration (Ward and Harr, 1990). From these 10 subsamples, samples for organic compounds were split using the cone splitter and samples for inorganic compounds were split using the churn splitter. The 40-mL discrete samples for volatile organic compound analysis were composited at the USGS, Arvada, Colorado.

\section{Volume and Loads}

A volume is the total quantity of water contributed from a basin by stormwater runoff passing a designated point in a given period of time. A volume was calculated for the duration of stormwater runoff using the discharge hydrograph. A load is the total quantity of a particular constituent contributed from a basin by stormwater runoff passing a sample point in a given time. 
Simulated stormwater-runoff volumes in cubic feet and stormwater-runoff constituent loads in pounds were calculated using the regional regression models for the stormwater-runoff volume and loads presented in Driver and Tasker (1990). Site specific, climatic, and storm characteristic data from this report were used with the regression models to simulate stormwater-runoff volume and loads. For each site the physical and land-use information needed to simulate a stormwater-runoff volume or load included drainage area, percentage of impervious area, population density, and percentage of land use, including residential, commercial, industrial, and nonurban. The climatic characteristics needed to simulate a stormwater-runoff volume or load were total storm rainfall, maximum 24-hour precipitation intensity that had a 2-year recurrence interval, mean annual rainfall, mean annual nitrogen load in precipitation, and mean minimum January temperature. For this study, stormwaterrunoff volume and loads were simulated using measured total rainfall from storms sampled. The approximate mean annual nitrogen load in precipitation is $\mathbf{1 3 . 3}$ pounds per acre [National

Atmospheric Deposition Program (IR-7)/National Trends Network, 1982-91]. The regression models simulated stormwater-runoff loads for chemical oxygen demand, dissolved and suspended solids, total nitrogen, total ammonia plus organic nitrogen, and total cadmium, copper, lead, and zinc.

\section{Laboratory Anaiysis}

Water temperature, fecal coliform, fecal streptococci, and concentrations of total chlorine, total cyanide, total phenols, and total oil and grease were determined for the first-flush sample. Water temperature and total chlorine concentration were determined at the time of sample collection using methods described for base-flow sampling. Fecal coliform and fecal streptococci colony densities were determined using membrane-filter methods described in Britton and Greeson (1989) at the USGS in Independence. Samples for total phenols and total oil and grease were analyzed by the USGS, Arvada, Colorado, using the methods and detection limits listed in table 2 . Total cyanide was analyzed by Enseco Rocky Mountain Analytical Laboratory, Arvada, Colorado, using the methods and detection limits listed in table 3.

The physical properties and chemical constituent analyses, methods, and detection limits used by the USGS, Arvada, Colorado for the flowweighted-composite samples are listed in table 2. Total antimony, total silver, and total thallium concentrations in the flow-weighted-composite sample were analyzed by Enseco Rocky Mountain Analytical Laboratory using methods and detection limits listed in table 3. The 5-day biochemical oxygen demand (hereafter referred to as biochemical oxygen demand) sample from the flow-weighted composite sample was split into a 1-L (liter) polyethylene bottle and analyzed at the city of Independence Water Pollution Control Laboratory, using the USEPA method 405.1 ( 5 days at $20^{\circ} \mathrm{C}$; U.S. Environmental Protection Agency, 1983) within 24 hours of sample collection.

Chemical constituents reported as total, total recoverable, or whole-water recoverable were analyzed from unfiltered samples. Dissolved constituents from the flow-weighted composite samples were determined from water samples filtered through a $0.45-\mu \mathrm{m}$ (micrometer) filter using a peristaltic pump.

Analyses of the flow-weighted-composite samples for specific conductance, $\mathrm{pH}$, alkalinity and bicarbonate concentrations were done at the USGS in Independence. Specific conductance and $\mathrm{pH}$ were determined by methods described in the base-flow sampling methods. Alkalinity and bicarbonate concentrations were determined by incremental titrations with $0.16 \mathrm{~N}$ (normal) sulfuric acid past the inflection point of the titration curve that occurs at a pH of about 4.5.

\section{Quaiity Assurance Sampies}

The representativeness of sample collection and handling was assessed by analyzing equipment and trip blanks, replicate samples, and matrix spiked sample sets. An equipment blank was analyzed for all properties and constituents listed in tables 2 and 3 , except for biochemical oxygen demand. 
Organic- and inorganic-free blank water was passed through all sample collection processing devices and treated as a regular flow-weighted composite sample. All constituent concentrations analyzed for in the equipment blank were less than the detection limit, except for the chemical oxygen demand [ $96 \mathrm{mg} / \mathrm{L}$ (milligrams per liter)], dissolved calcium $(0.03 \mathrm{mg} / \mathrm{L})$, dissolved phosphorus $(0.03$ $\mathrm{mg} / \mathrm{L})$, total ammonia as nitrogen $(0.12 \mathrm{mg} / \mathrm{L})$, suspended solids at $105^{\circ} \mathrm{C}(5 \mathrm{mg} / \mathrm{L})$, total organic carbon $(27 \mathrm{mg} / \mathrm{L}$ ), chromium [ $3 \mu \mathrm{g} / \mathrm{L}$ (micrograms per liter)], and methylene chloride $(0.03 \mathrm{mg} / \mathrm{L})$. The cleaning procedure used for equipment, rinsing with methanol, probably resulted in the large chemical oxygen demand and total organic carbon concentrations. On recognition of the data anomalies, the cleaning procedure was modified to exclude the use of methanol.

A trip blank was analyzed for volatile organic compounds to determine if diffusion of these compounds occurred through the septum caps during shipping and storage. A trip blank is a sample of organic-free water filled and shipped with the empty sample collection bottles and taken to the study sites with the collection bottles, never opened onsite, and returned to the laboratory with the samples. One trip blank was analyzed for samples collected at site 3 on July 9, 1992. All constituents were less than the detection limits, except for methylene chloride, which had a concentration of $0.5 \mu \mathrm{g} / \mathrm{L}$ (detection limit was 0.2 $\mu \mathrm{g} / \mathrm{L})$.

Analysis of replicate samples was used to assess the precision of sample collection from sample splitters, shipping and storage, and laboratory analyses (M.W. Sandstrom, U.S. Geological Survey, written commun., 1990). Replicate samples for inorganic analyses were split from a flow-weighted-composite sample using a churn splitter. The data for the inorganic replicate samples are listed in table 4 , at the back of this report.

Matrix spiked sample sets were analyzed to determine analytical recoveries for the different conditions that a sample undergoes. Matrix spiked sample sets for pesticides and acidic, basic, and neutral organic compounds included two replicate field spiked samples, a replicate laboratory spiked sample, and a replicate unspiked sample. A matrix spiked sample set for volatile organic compounds included a replicate laboratory spiked sample and a replicate unspiked sample. All samples were split from a flow-weighted composite sample using a cone splitter and spiked with a selected set of analytes of known concentrations onsite for replicate field spiked samples and at the laboratory for laboratory spiked samples. Comparison of the two replicate field spiked samples was used to assess the precision of the sample collection from the cone splitter, shipping and storage conditions, and laboratory analyses. Degradation during shipping also can be assessed from the results of a replicate laboratory spiked sample and a replicate field spiked sample. The replicate unspiked sample is analyzed to determine the ambient constituent concentrations. If a constituent is detected in the unspiked sample, the concentration is then subtracted from the constituent concentration determined in the other three replicate spiked samples to compute the percent recoveries.

Concentrations and percent recoveries for the matrix spiked sample sets for pesticides are listed in tables 5 and 6, at the back of this report. Results for the matrix spiked sample sets for acidic, basic, and neutral organic compounds are listed in table 7 , at the back of this report, and results for the matrix spiked sample sets for volatile organic compounds are listed in table 8 , at the back of this report.

\section{BASE-FLOW DATA}

A total of 226 samples were collected at 193 sites (fig. 2). Some sites were sampled more than once because concentrations of selected constituents were previously detected in a sample or were expected to be present from certain land uses. For each sample, discharge, specific conductance, $\mathrm{pH}$, water temperature, total chlorine, total copper, total detergents, and total phenols were determined. A summary of the results is listed in table 9, at the back of this report. The maximum discharge, 10.1 $\mathrm{ft}^{3} / \mathrm{s}$ (cubic feet per second), was measured near the mouth of Rock Creek (fig. 2). The pH of five samples exceeded 9.0 and these samples had a range of discharge from 0.003 to $0.15 \mathrm{ft}^{3} / \mathrm{s}$ and a range of specific conductance from 507 to 773 $\mu \mathrm{S} / \mathrm{cm}$ (microsiemens per centimeter at $25^{\circ} \mathrm{C}$ ). Total chlorine was detected 45 times at 39 sites, 
with a maximum concentration of $0.9 \mathrm{mg} / \mathrm{L}$. Total copper and total phenols were not detected at any of the sites. Total detergents were detected at site $S 19$ (fig. 2) with a concentration of $0.3 \mathrm{mg} / \mathrm{L}$ at a discharge of $0.02 \mathrm{ft}^{3} / \mathrm{s}$. The results for the baseflow samples are listed in table 10, at the back of this report.

\section{Stormwater-Runoff Sampling Data}

The following sections contain data from stormwater-runoff sample collection at sites 1 to 5 from July 9, 1992, through February 11, 1993. These sections discuss rainfall, bacteria, inorganic and organic compound concentrations, and observed and simulated loads.

\section{Rainfall and Discharge Characteristics}

The rainfall and discharge characteristics for the storms sampled from sites 1 to 5 are listed in table 11, at the back of this report. Rainfall intensities and discharge hydrographs of the storms sampled are shown in figures 3 to 7 . All of the storms sampled had more than 0.10 in. rainfall. At the time of sampling there had been less than 0.10 in. of rainfall in the 72 hours preceding the storm, except for the stormwater runoff sampled at site 3 beginning on July 9, 1992 (which had 0.10 in. of rainfall). The rainfall depths for the storms sampled ranged from 0.22 to 0.98 in. Rainfall depths for the storms at site 3 on July 9 to 10, 1992, were collected from the rain gage at site $\mathrm{RN} 1$ and the depth at site 2 on July 22, 1992, was collected from an onsite non-recording rain gage, because of equipment malfunction at rain gage $\mathrm{RN} 2$ at the time of the storms. Rainfall durations ranged from 20 to 324 minutes. The storm sampled at sites 1 and 4 on February 11, 1993, was preceded by 9 in. of snow that had almost melted at the time of the storm. The percentage of discharge from precipitation during sampled storms ranged from 6 percent at site 1 to 66 percent at site 3 .

\section{Bacteria}

Analyses of bacteria from sites 1 to 5 are listed in table 12, at the back of this report. Fecal coliform ranged from $500 \mathrm{col} / 100 \mathrm{~mL}$ (colonies per 100 milliliters) at site 4 to $290,000 \mathrm{col} / 100 \mathrm{~mL}$ at site 1; 14 of 35 estimated colony counts at all sites were based on non-ideal colony counts. Fecal streptococci ranged from $1,900 \mathrm{col} / 100 \mathrm{~mL}$ at site 2 to $500,000 \mathrm{col} / 100 \mathrm{~mL}$ at site $1 ; 8$ of 35 estimated colony counts at all sites were based on non-ideal colony counts. A fecal coliform to fecal streptococci ratio of 4.0 or more indicates human wastes and a ratio of 0.7 or less indicates animal waste (Henry and Heinke, 1989). The ratio from 35 bacteria samples averaged 0.9 . The minimum fecal coliform to fecal streptococci ratio was 0.01 at site 5 , and the maximum fecal coliform to fecal streptococci ratio was 4.1 at site 5 . The discharge at the time of bacteria sample collection ranged from $0.31 \mathrm{ft}^{3} / \mathrm{s}$ at site 5 to $260 \mathrm{ft}^{3} / \mathrm{s}$ at site 3 .

\section{Constituent Concentrations}

For the first-flush samples total chlorine concentrations ranged from less than 0.1 to 0.2 $\mathrm{mg} / \mathrm{L}$ with two detections from seven samples (table 12). Total cyanide was not detected in 13 first-flush samples. Total phenols ranged from less than 1 to $7 \mu \mathrm{g} / \mathrm{L}$ for 13 samples with 12 detections. Total oil and grease ranged from less than 1 to 16 $\mu \mathrm{g} / \mathrm{L}$ for 13 samples with 8 detections. Discharge at the time of sample collection for the first-flush samples ranged from $0.40 \mathrm{ft}^{3} / \mathrm{s}$ at site 5 to $260 \mathrm{ft}^{3} / \mathrm{s}$ at site 3 .

The values of selected physical properties and constituent concentrations of the flow-weighted composite samples are listed in table 13, at the back of this report. Specific conductance ranged from $68 \mu \mathrm{S} / \mathrm{cm}$ at site 3 to $26,500 \mu \mathrm{S} / \mathrm{cm}$ at site 5 . The chemical oxygen demand for all sites ranged from $36 \mu \mathrm{g} / \mathrm{L}$ to $1,600 \mu \mathrm{g} / \mathrm{L}$ at site 3 . The biochemical oxygen demand ranged from $13 \mathrm{mg} / \mathrm{L}$ at site 3 to greater than $650 \mathrm{mg} / \mathrm{L}$ at site 1 . Dissolved solids 


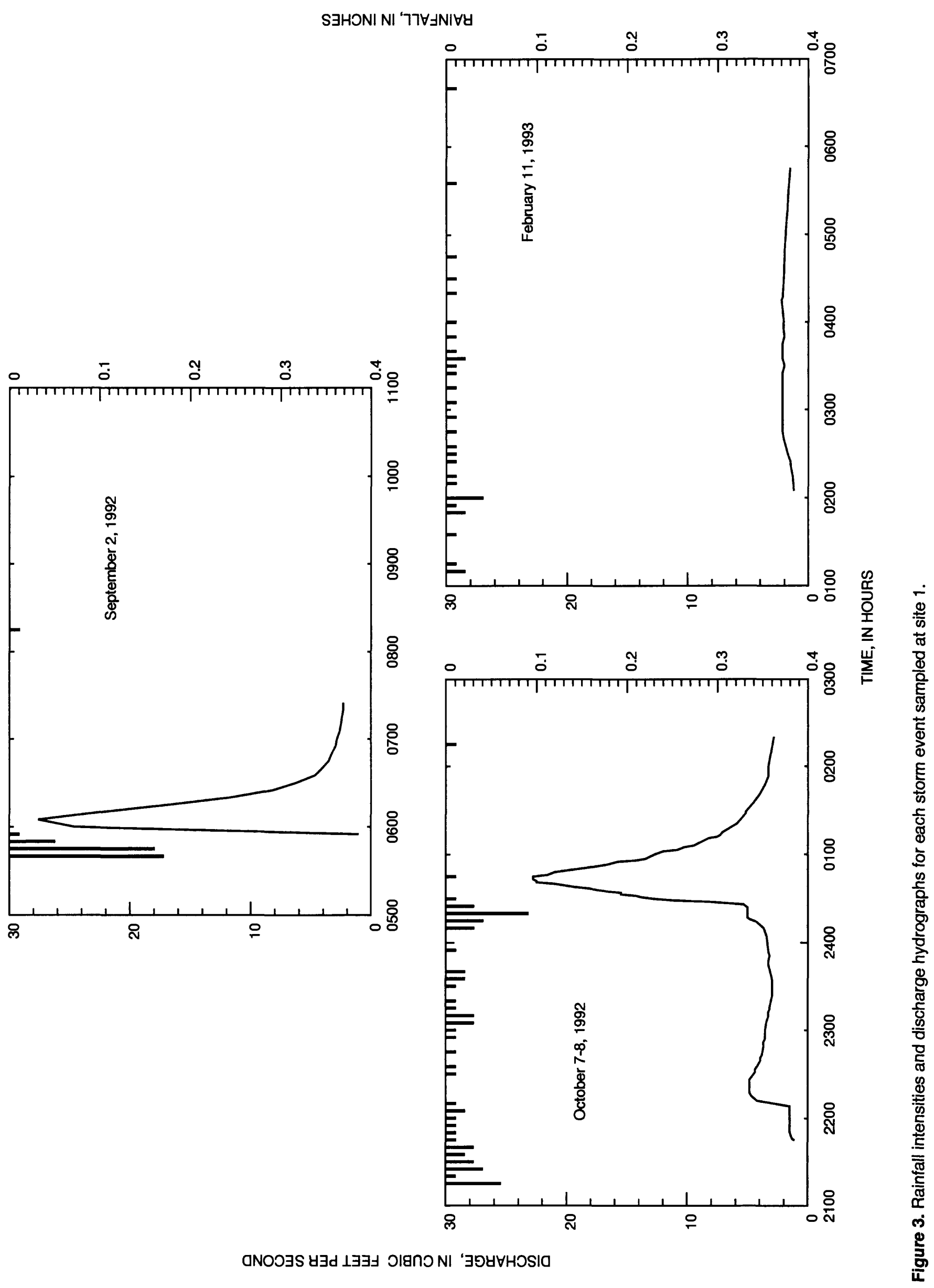




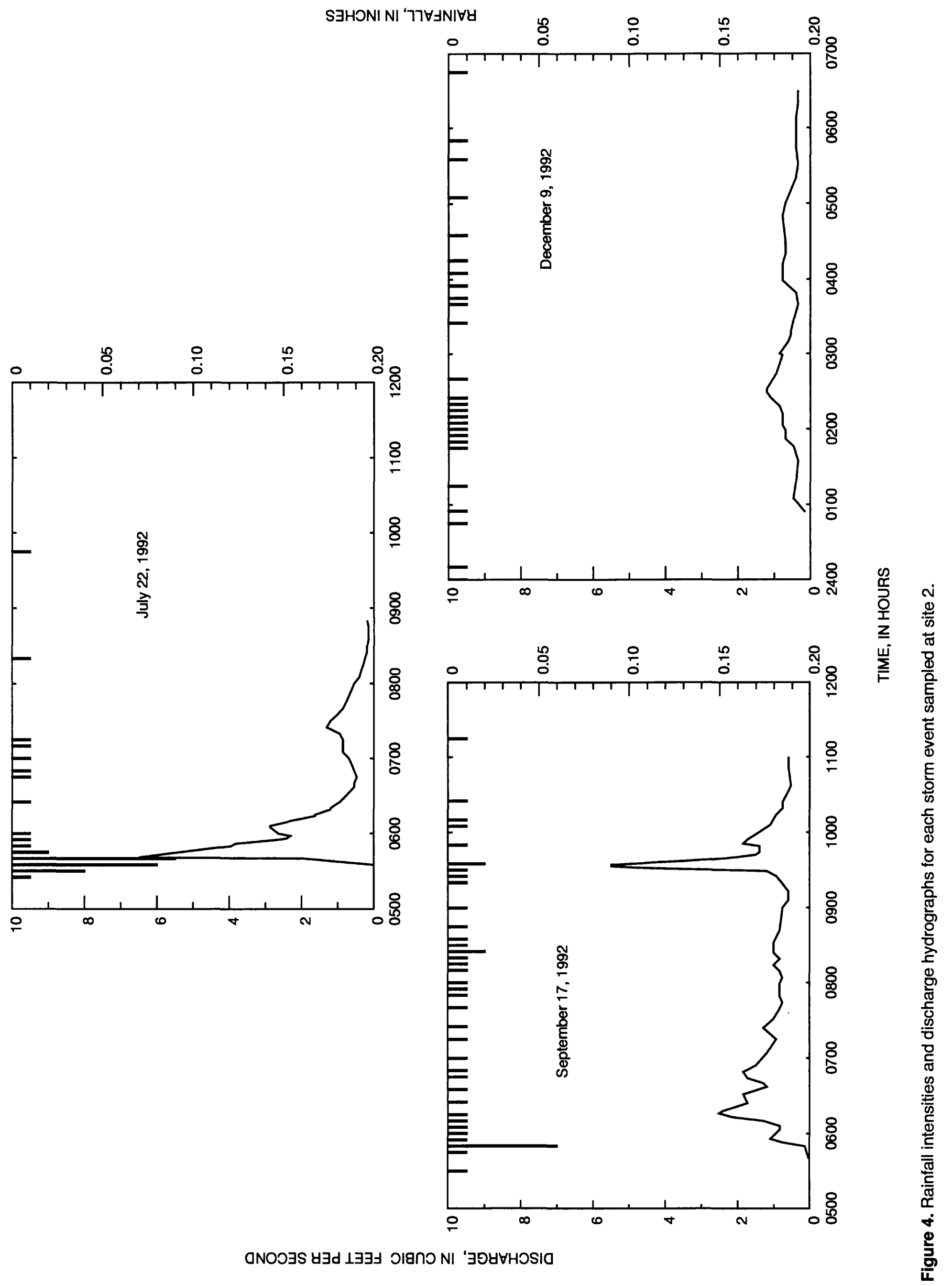




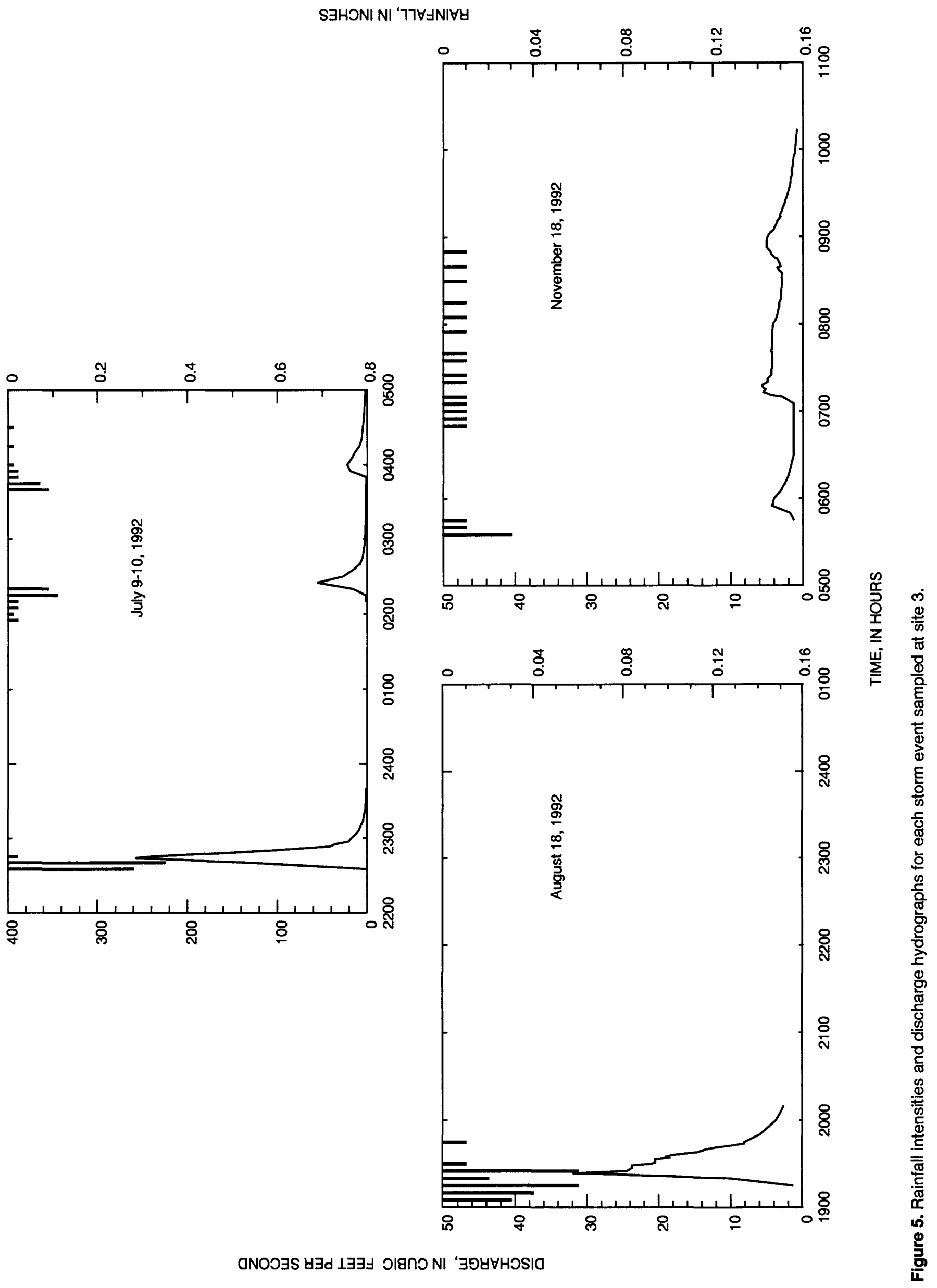




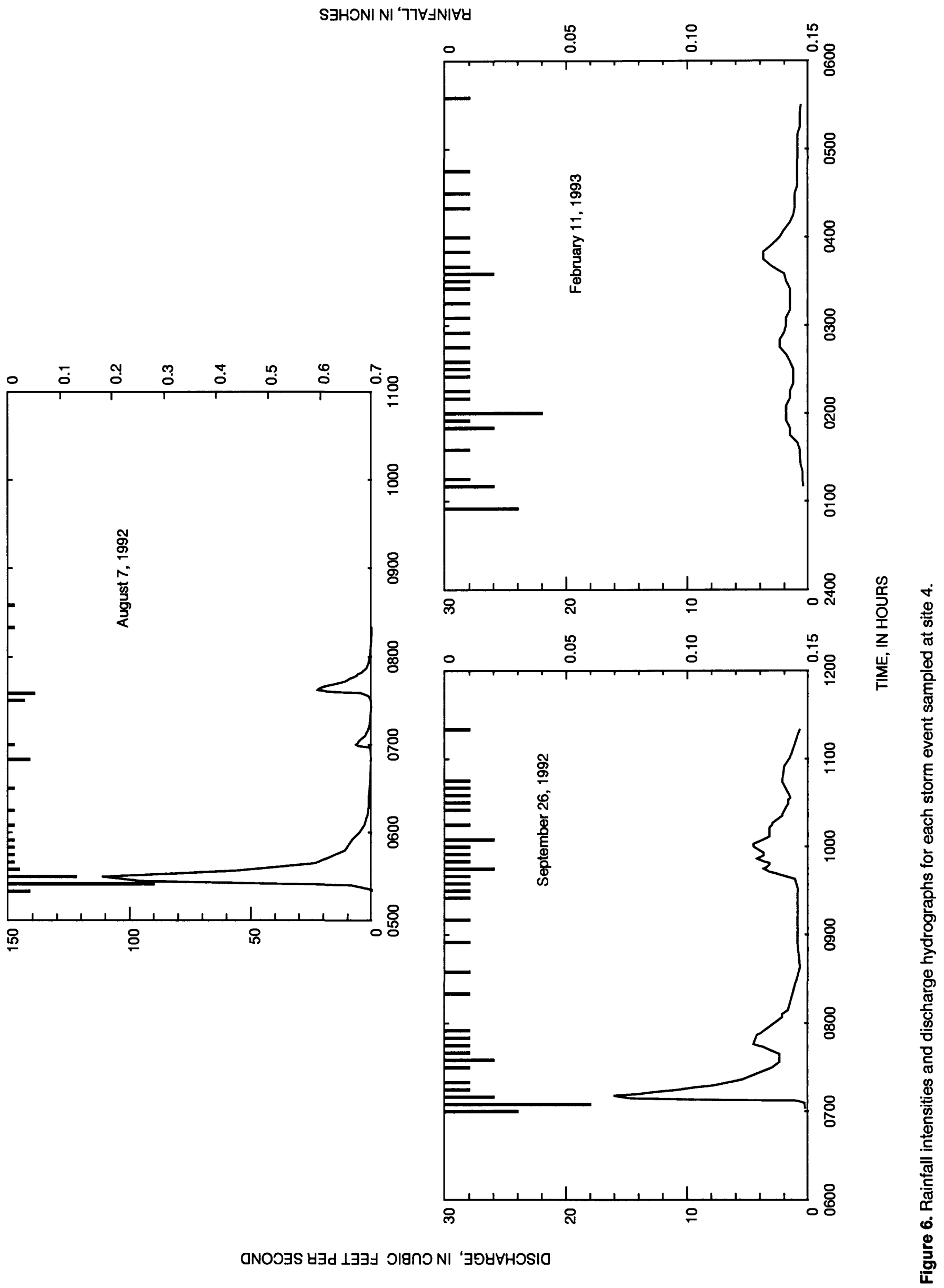




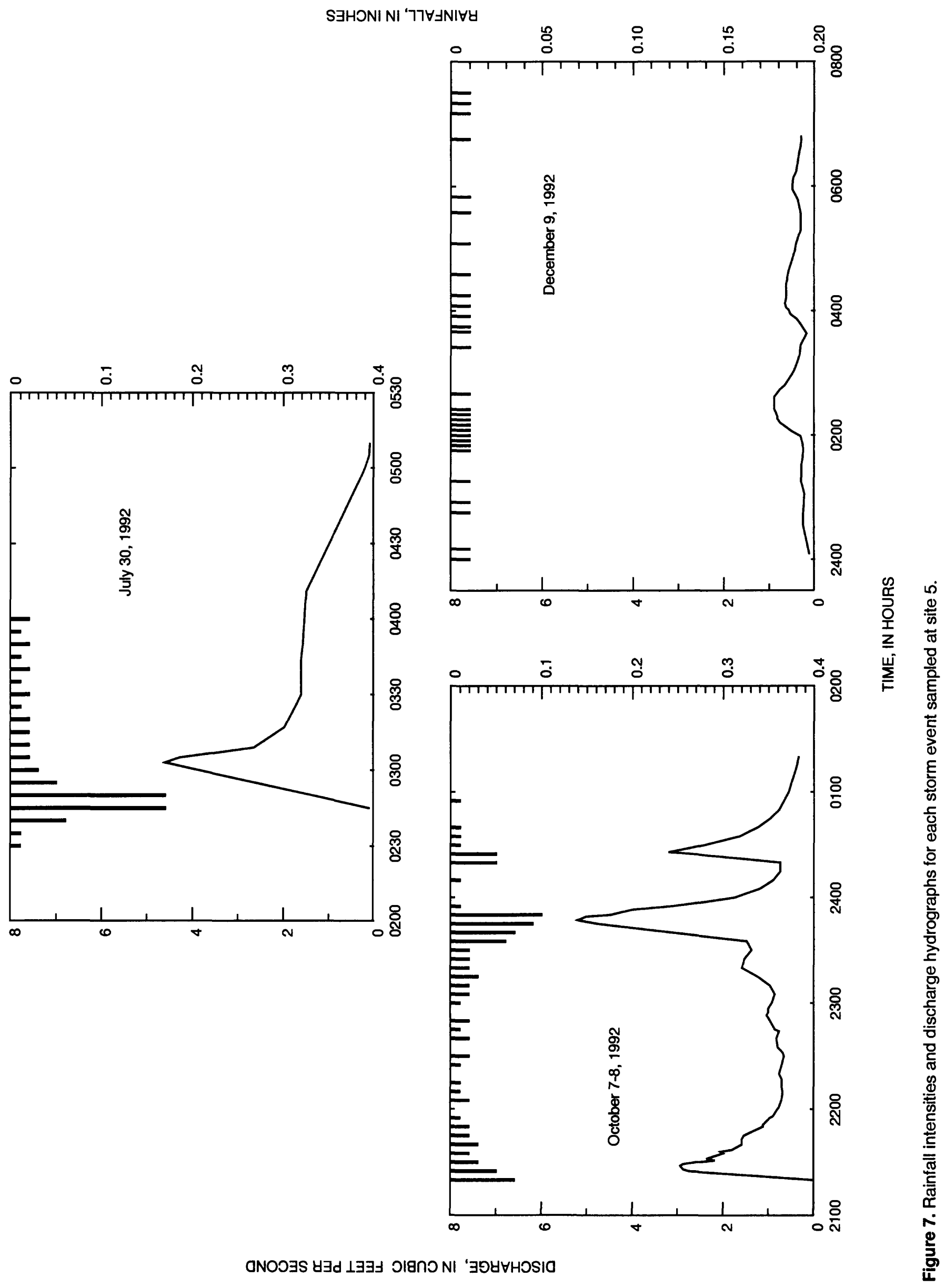


concentrations ranged from $34 \mathrm{mg} / \mathrm{L}$ at site 3 to $14,700 \mathrm{mg} / \mathrm{L}$ at site 5 . The site 5 basin includes large unsheltered piles of road salt. Total suspended solids concentrations ranged from $38 \mathrm{mg} / \mathrm{L}$ at site 3 to $1,200 \mathrm{mg} / \mathrm{L}$ at site 5 . Nitrite plus nitrate as nitrogen concentrations ranged from less than 0.05 $\mathrm{mg} / \mathrm{L}$ at site 1 to $1.5 \mathrm{mg} / \mathrm{L}$ at site 4 . Total ammonia as nitrogen concentrations ranged from less than $0.01 \mathrm{mg} / \mathrm{L}$ at site 1 to $1.0 \mathrm{mg} / \mathrm{L}$ at site 3 . Mean total ammonia plus organic nitrogen as nitrogen concentrations ranged from $0.2 \mathrm{mg} / \mathrm{L}$ at site 5 to $3.3 \mathrm{mg} / \mathrm{L}$ at site 1. Mean total phosphorus concentrations ranged from $0.12 \mathrm{mg} / \mathrm{L}$ at site 5 to $1.3 \mathrm{mg} / \mathrm{L}$ at site 1 and dissolved phosphorus concentrations ranged from less than $0.01 \mathrm{mg} / \mathrm{L}$ at sites 1 and 5 to 0.42 $\mathrm{mg} / \mathrm{L}$ at site 3 . Mean total organic carbon concentrations ranged from 12 to $410 \mathrm{mg} / \mathrm{L}$ at site 3 .

Total cyanide concentrations were detected twice at the detection limit of $0.01 \mathrm{mg} / \mathrm{L}$ at site 5 .

\section{Trace Eiements}

The sources of trace elements in streams are associated with both natural occurring chemical weathering and human activities (Viessman and Hammer, 1985). Concentrations for the wholewater recoverable trace element analyses for the flow-weighted composite samples are presented in table 14, at the back of this report. Antimony, beryllium, selenium, and thallium were not detected. The mercury concentration was 0.2 $\mu \mathrm{g} / \mathrm{L}$ at site 4 and 0.1 and $0.3 \mu \mathrm{g} / \mathrm{L}$ at site 5 . The following trace elements were detected (concentrations are listed in parentheses): arsenic (1 to 10 $\mu \mathrm{g} / \mathrm{L}$ ), cadmium (less than 1 to $40 \mu \mathrm{g} / \mathrm{L}$ ), chromium (less than 1 to $99 \mu \mathrm{g} / \mathrm{L}$ ), copper ( 8 to $130 \mu \mathrm{g} / \mathrm{L}$ ), lead (20 to $800 \mu \mathrm{g} / \mathrm{L}$ ), nickel (3 to 37 $\mu \mathrm{g} / \mathrm{L})$, and zinc $(110$ to $6,200 \mu \mathrm{g} / \mathrm{L})$. The largest concentrations of arsenic and chromium occurred at site 1 . The largest mean concentrations of cadmium, lead, mercury, nickel, and zinc occurred at site 5 . The only detection of silver was at site 4 with a concentration of $12 \mu \mathrm{g} / \mathrm{L}$.

\section{Pesticides}

The results of the whole-water recoverable analyses for the pesticides from the flow-weighted composite samples are presented in table 15 , at the back of this report. The concentrations are compared to Missouri water-quality criteria for human health protection-fish consumption (Missouri Department of Natural Resources, 1991b). Chlordane concentrations of $0.1,0.2$, and $0.4 \mu \mathrm{g} / \mathrm{L}$ at site 1 and two detections of $0.1 \mu \mathrm{g} / \mathrm{L}$ at site 2 exceeded the water-quality criteria of $0.00048 \mu \mathrm{g} / \mathrm{L}$. At site 1 , cis-chlordane and transchlordane had concentrations of $0.1 \mu \mathrm{g} / \mathrm{L}$. At site 4 , concentrations of $p, p^{\prime}$-DDD and $p, p^{\prime}$-DDT were at the detection limit of $0.1 \mu \mathrm{g} / \mathrm{L}$, which exceeded the water-quality criteria of 0.00024 $\mu \mathrm{g} / \mathrm{L}$. Concentrations of diazinon were 0.2 and 1.0 $\mu \mathrm{g} / \mathrm{L}$ at site 1 ; concentrations of $0.1 \mu \mathrm{g} / \mathrm{L}$ were detected twice at site 2 ; concentrations of 0.2 and $0.1 \mu \mathrm{g} / \mathrm{L}$ were detected at site 3 ; and a concentration of $0.2 \mu \mathrm{g} / \mathrm{L}$ was detected at site 4 . A dieldrin concentration of $0.05 \mu \mathrm{g} / \mathrm{L}$ at site 1 exceeded the water-quality criteria of 0.000076 $\mu \mathrm{g} / \mathrm{L}$. Lindane was detected at the detection limit of $0.03 \mu \mathrm{g} / \mathrm{L}$ at site 4 . The polychlorinated biphenyl Aroclor 1248 concentration of $2.4 \mu \mathrm{g} / \mathrm{L}$ at site 4 exceeded the water-quality criteria of $0.000045 \mu \mathrm{g} / \mathrm{L}$.

\section{Voiatiie Organic Compounds}

Of the 63 volatile organic compounds analyzed, 13 compounds were detected a total of 27 times. The results of the whole-water recoverable analyses of the flow-weighted composite samples from sites 1 to 5 are listed in table 16, at the back of this report. The concentrations of volatile organic compounds ranged from 0.2 to 5.1 $\mu \mathrm{g} / \mathrm{L}$. Naphthalene was detected with the largest concentration of $5.1 \mu \mathrm{g} / \mathrm{L}$ at site 2 and was detected a total of five times at sites $1,2,3$, and 4 . Ten compounds were detected at site 2 , and nine of the 
detections were from the same flow-weighted composite sample. Site 3 had eight detections of volatile organic compounds. The following compounds were detected at sites 1 to 5 during this study: benzene; $n$-butylbenzene; dichlorodifluoromethane; ethylbenzene; $p$-isopropyltolune; 1,3,5-trimethylbenzene (mesitylene); dichloromethane (methylene chloride); naphthalene; $n$ propylbenzene; 1,2,4-trimethylbenzene (pseudocumene); styrene; toluene; and xylene. Concentrations of volatile organic compounds detected did not exceed any of the listed water-quality criteria for human health protection-fish consumption (Missouri Department of Natural Resources, 1992).

\section{Acidic, Basic, and Neutral Semi-Volatile Organic Compounds}

The results of the whole-water recoverable analyses for the acidic, basic, and neutral semivolatile organic compounds from the composite samples are presented in table 17, at the back of this report. Concentrations of these compounds were compared to Missouri water-quality criteria for human health protection-fish consumption (Missouri Department of Natural Resources, 1992). Concentrations of di-2-ethylhexyl phthalate were $6.0 \mu \mathrm{g} / \mathrm{L}$ at site $1 ; 6,7$, and $8 \mu \mathrm{g} / \mathrm{L}$ at site 2 ; and $10 \mu \mathrm{g} / \mathrm{L}$ at site 3 , and all concentrations exceeded the water-quality criteria of 5.9 $\mu \mathrm{g} / \mathrm{L}$. A concentration of di-2-ethylhexyl phthalate was at the detection limit of $5 \mu \mathrm{g} / \mathrm{L}$ at site 5 . Di-2ethylhexyl phthalate is one of the most widely used plasticizers (Smith and others, 1988). Concentrations of fluoranthene were $18 \mu \mathrm{g} / \mathrm{L}$ at site 1,15 $\mu \mathrm{g} / \mathrm{L}$ at site 4 , and $10 \mu \mathrm{g} / \mathrm{L}$ at site 5 . Concentrations of phenanthrene were $7 \mu \mathrm{g} / \mathrm{L}$ at sites 1 and 4 , and $6 \mu \mathrm{g} / \mathrm{L}$ at site 5 . Concentrations of pyrene were $13 \mu \mathrm{g} / \mathrm{L}$ at site $1,11 \mu \mathrm{g} / \mathrm{L}$ at site 4 , and $7 \mu \mathrm{g} / \mathrm{L}$ at site 5. The detections of fluoranthene, phenanthrene, and pyrene occurred in the same flowweighted-composite sample for each site. Fluoran- thene, phenanthrene, and pyrene, classified as polycyclic aromatic hydrocarbons, can originate in surface water from atmospheric deposition, surface runoff, and industrial and municipal wastewater effluents (Smith and others, 1988).

\section{Volume and Loads}

The observed volume in cubic feet and loads in pounds for each site for every constituent with at least one detection and simulations for storm volume and loads calculated with the Driver and Tasker (1990) equations are listed in tables 18 to 22 , at the back of this report. The observed and simulated volume and loads were compared to the second storm sampled at each site using the following equation:

$$
\frac{\text { Simulated value }- \text { Observed value }}{\text { Observed value }} \times 100=\text { percent difference }(2)
$$

For the storms sampled on October 7, 1992, at site 1 , chemical oxygen demand, total phosphorus, copper, and zinc loads had less than a 50 percent difference between the observed and the simulated values. For the storms sampled on September 7, 1992, at site 2, dissolved solids and dissolved phosphorus loads had less than a 50 percent difference between observed and simulated values. For the storms sampled at site 3 on August 18, 1992 , volume, chemical oxygen demand, total ammonia plus organic nitrogen, total nitrogen, total phosphorus, cadmium, and zinc loads had a 50 percent or less difference between the observed and simulated values. For the storm sampled on September 26, 1992, at site 4, the difference between the simulated volume and all the simulated loads and the observed volume and loads was greater than 60 percent. For the storm sampled at site 5 on October 7, 1992, the simulated and observed loads were less than 50 percent for chemical oxygen demand, suspended solids, and lead. 


\section{REFERENCES CITED}

Benson, M.A., and Dalrymple, Tate, 1967, General field and office procedures for indirect discharge measurements: U.S. Geological Survey Techniques of Water-Resources Investigations, book 3, chap. A1, $30 \mathrm{p}$.

Bodhaine, G.L., 1968, Measurement of peak discharge at culverts by indirect methods: U.S. Geological Survey Techniques of Water-Resources Investigations, book 3, chap. A3, 60 p.

Britton, L.J., and Greeson, P.E., eds., 1989, Methods for collection and analysis of aquatic biological and microbiological samples: U.S. Geological Survey Techniques of Water-Resources Investigations, book 5 , chap. A4, $363 \mathrm{p}$.

Buchanan, T. J., and Somers, W.P., 1976, Discharge measurements at gaging stations: U.S. Geological Survey Techniques of Water-Resources Investigations, book 3, chap. A8, 65 p.

Buchanan, T. J., and Somers, W.P., 1978, Stage measurement at gaging stations: U.S. Geological Survey Techniques of Water-Resources Investigations, book 3, chap. A7, $28 \mathrm{p}$.

City of Independence, 1993, City of Independence comprehensive plan: Independence, Mo.

Dalrymple, Tate, and Benson, M.A., 1967, Measurement of peak discharge by the slope-area method: U.S. Geological Survey Techniques of WaterResources Investigations, book 3, chap. A2, 12 p.

Driver, N.E., and Tasker, G.D., 1990, Techniques for estimation of storm-runoff loads, volumes, and selected constituent concentrations in urban watersheds in the United States: U.S. Geological Survey Water-Supply Paper 2363, 40 p.

Fishman, M.J., 1993, Methods of analysis by the U.S. Geological Survey National Water Quality Laboratory--Determination of inorganic and organic constituents in water and fluvial sediment: U.S. Geological Survey Open-File Report 93-125, 217 p.
Fishman, M.J., and Friedman, L.C., eds., 1989, Methods for determination of inorganic substances in water and fluvial sediments: U.S. Geological Survey Techniques of Water-Resources Investigations, book 5 , chap. A1, $545 \mathrm{p}$.

Guy, H.P., and Norman V.W., 1973, Field methods for measurement of fluvial sediment: U.S. Geological Survey Techniques of Water-Resources Investigations, book 3, chap. C2, 59 p.

Henry, J.G., and Heinke, G.W., 1989, Environmental science and engineering: Englewood Cliffs, N.J., Prentice-Hall, 728 p.

Hershfield, D.M., 1961, Rainfall frequency atlas of the United States: Weather Bureau Technical Paper 40, U.S. Government Printing Office, Washington, 61 p.

Kennedy, E.J., 1983, Computation of continuous records of streamflow: U.S. Geological Survey Techniques of Water-Resources Investigations, book 3, chap. A13, 53 p.

Missouri Department of Natural Resources, 1991, Storm water regulations--Proposed rule: Missouri Register, v. 16, no. 15, p. 1,077-1,087.

1992, Missouri water-quality standards--Chapter 7, Water quality: Jefferson City, Clean Water Commission, $100 \mathrm{p}$.

National Atmospheric Deposition Program (IR-7)/ National Trends Network, 1982-1991: NADP/NTN Coordination Office, Natural Resources Ecology Laboratory, Colorado State University, Fort Collins, Colorado.

National Oceanic and Atmospheric Administration, 1991, 1990 local climatological data, annual summary with comparative data, Kansas City, Missouri, International Airport: Asheville, N.C., National Climatological Data Center, 8 p.

Patton, C.J., and Truitt, E.P., 1992, Methods of analysis by the U.S. Geological Survey National Water Quality Laboratory--Determination of total phosphorus by a Kjeldahl digestion method and an automated colorimetric finish that includes dialysis: U.S. Geological Survey Open-File Report 92-146, 39 p. 
Porterfield, George, 1977, Computation of fluvial-sediment discharge: U.S. Geological Survey Techniques of Water-Resources Investigations, book 3, chap. C3, $66 \mathrm{p}$.

Rantz, S.E., and others, 1982, Measurement and computation of streamflow--Volume 1. Measurement of stage and discharge: U.S. Geological Survey WaterSupply Paper 2175, $284 \mathrm{p}$.

Smith, J.A., Witkowski, P.J., and Fusillo, T.V., Manmade organic compounds in the surface waters of the United States--A review of current understanding: U.S. Geological Survey Circular 1007, 92 p.

U.S. Environmental Protection Agency, 1983, Methods for chemical analysis of water and wastes: Cincinnati, Ohio, Environmental Monitoring and Support Laboratory, EPA-600/4-79-020.

1988, Methods for determination of organic compounds in drinking water: Cincinnati, Ohio, Environmental Monitoring Systems Laboratory, EPA600/4-88-039.

1990, National pollutant discharge elimination system permit application regulations for stormwater discharges, final rule: U.S. Federal Register, v. 55 , no. 222 . p. $47,989-48,091$.
U.S. Environmental Protection Agency, 1991, Protection of environmental method 608--Organochlorine pesticides and PCBs: U.S. Code of Federal Regulations, Title 40, part 136, app. A, July 1, 1991, p. 398418.

Viessman, W., Jr., and Hammer, M.J., 1985, Water supply and pollution control (4th ed.): New York, Harper and Row, $797 \mathrm{p}$.

Ward, J. R., and Harr, C.A., eds., 1990, Methods for collection and processing of surface-water and bedmaterial samples for physical and chemical analyses: U.S. Geological Survey Open-File Report 90-140, $71 \mathrm{p}$.

Wershaw, R. L., Fishman, M.J., Grabbe, R.R., and Lowe, L.E., eds., 1987, Methods for the determination of organic substances in water and fluvial sediments: U.S. Geological Survey Techniques of Water-Resources Investigations, book 5, chap. A3, $80 \mathrm{p}$. 
TABLES 
Table 1. Selected data for study sites and drainage basins and location of rain gages [--, no data; NPDES, National Pollution Discharge Elimination System]

\begin{tabular}{|c|c|c|c|c|c|c|c|}
\hline $\begin{array}{c}\text { Sampling } \\
\text { slte } \\
\text { number } \\
\text { (fig. 1) }\end{array}$ & $\begin{array}{l}\text { NPDES } \\
\text { permlt site } \\
\text { number }\end{array}$ & $\begin{array}{l}\text { U.S. } \\
\text { Geological } \\
\text { Survey } \\
\text { statlon } \\
\text { number }\end{array}$ & $\begin{array}{l}\text { Name of } \\
\text { samplling site }\end{array}$ & $\begin{array}{c}\text { Latltude } \\
\text { longltude } \\
\text { locatlon, In } \\
\text { degrees, } \\
\text { minutes, } \\
\text { seconds }\end{array}$ & $\begin{array}{c}\text { Dralnage } \\
\text { area, In } \\
\text { square } \\
\text { mlles }\end{array}$ & $\begin{array}{l}\text { Predominant } \\
\text { land use In } \\
\text { dralnage area }\end{array}$ & $\begin{array}{l}\text { Percentage } \\
\text { of area } \\
\text { covered by } \\
\text { Impervlous } \\
\text { surface }\end{array}$ \\
\hline${ }^{a} 1$ & 17 & 06893635 & Sugar Creek tributary & $\begin{array}{r}390529 \\
0942644\end{array}$ & 0.454 & $\begin{array}{l}\text { Single-family } \\
\text { residential }\end{array}$ & 42 \\
\hline$b_{2}$ & 12 & 06893950 & Spring Branch tributary & $\begin{array}{r}390636 \\
0942234\end{array}$ & .161 & $\begin{array}{l}\text { High-density } \\
\text { residential }\end{array}$ & 29 \\
\hline$b_{3}$ & 13 & 06893930 & Crackerneck Creek tributary & $\begin{array}{r}390409 \\
0942241\end{array}$ & .177 & $\begin{array}{l}\text { Strip commer- } \\
\text { cial }\end{array}$ & 62 \\
\hline$a_{4}$ & 14 & 06893596 & Unnamed Rock Creek tributary & $\begin{array}{c}390509 \\
0942516\end{array}$ & .224 & $\begin{array}{l}\text { Office space/ } \\
\text { commercial }\end{array}$ & 61 \\
\hline$b_{5}$ & I5 & 06893960 & $\begin{array}{l}\text { Unnamed Spring Branch tribu- } \\
\text { tary }\end{array}$ & $\begin{array}{c}390533 \\
0942142\end{array}$ & .046 & $\begin{array}{l}\text { Light indus- } \\
\text { trial }\end{array}$ & 35 \\
\hline RN1 & -- & $\begin{array}{l}39053009- \\
4250701\end{array}$ & $\begin{array}{l}\text { Rooftop at downtown post } \\
\text { office }\end{array}$ & $\begin{array}{c}390530 \\
0942507\end{array}$ & -- & -- & -- \\
\hline RN2 & -- & $\begin{array}{l}39055409- \\
4214101\end{array}$ & $\begin{array}{l}\text { City storage lot at Indepen- } \\
\text { dence Avenue and Turner } \\
\text { Road }\end{array}$ & $\begin{array}{r}390554 \\
0942141\end{array}$ & -- & -- & -- \\
\hline
\end{tabular}

${ }^{a}$ Rain gage data from RN1 were used for site.

${ }^{b}$ Rain gage data from RN2 were used for site except where specified. 
Table 2. Methods, detection limits, preservations, and bottle types used for determination of constituent concentrations at the U.S. Geological Survey, Arvada, Colorado

[T, total; analytical method number I references U.S. Geological Survey methods and methods number prefixes; $\mu \mathrm{S} / \mathrm{cm}$, microsiemens per centimeter at 25 degrees Celsius; $\mathrm{P250}, 250$-milliliter polyethylene; $\mathrm{NA}$, not applicable; mg/L, milligrams per liter; $\mathrm{H}_{2} \mathrm{SO}_{4}$, sulfuric acid; ${ }^{\circ} \mathrm{C}$, degrees Celsius; P1000, 1000-milliliter polyethylene; GB125, 125-milliliter brown glass; D, dissolved; AA, atomic absorption; $\mathrm{HNO}_{3}$, nitric acid; PA250, 250-milliliter polyethylene, acid rinsed; $\mathrm{CaCO}_{3}$, calcium carbonate; $\mathrm{ET}$, electrometric titration; IC, ion-exchange chromatography; P500, 500-milliliter polyethylene; S, suspended; ASF, automated-segmented flow, colorimetric; PB 125, 125-milliliter brown polyethylene; Cd, cadmium; WWR, whole-water recoverable; $\mathrm{NaOH}$, sodium hydroxide; analytical method number E references U.S. Environmental Protection Agency methods; GFAA, graphite furnace atomic absorption; $\mu \mathrm{g} / \mathrm{L}$, micrograms per liter; $\mathrm{DCP}$, direct-current plasma; $\mathrm{K}_{2} \mathrm{CrO}_{3}$, potassium dichromate; GA250, 250-milliliter glass, acid rinsed; analytical method number $\mathrm{O}$ references U.S. Geological Survey methods and methods number prefixes; $\mathrm{H}_{3} \mathrm{PO}_{4}$ $\mathrm{CuSO}_{4}$, phosphoric acid/copper sulfate; GB1000; 1,000-milliliter brown glass; BHC, benzene hexachloride; GC/ECD, gas chromatography/electron capture detector, DDD, 1,1-Dichloro-2,2-bis( $p$-Chlorophenyl)ethane; DDE, Dichloro diphenyl dichloroethylene; DDT, dichloro diphenyl trichloroethane; PCB, polychlorinated biphenyl; GC/MS, gas chromatography/mass spectrometric detector; $\mathrm{HCl}$, hydrochloric acid; GB40, 40-milliliter brown glass septum vial; all physical properties and constituents were analyzed from flow-weighted composite samples unless noted otherwise]

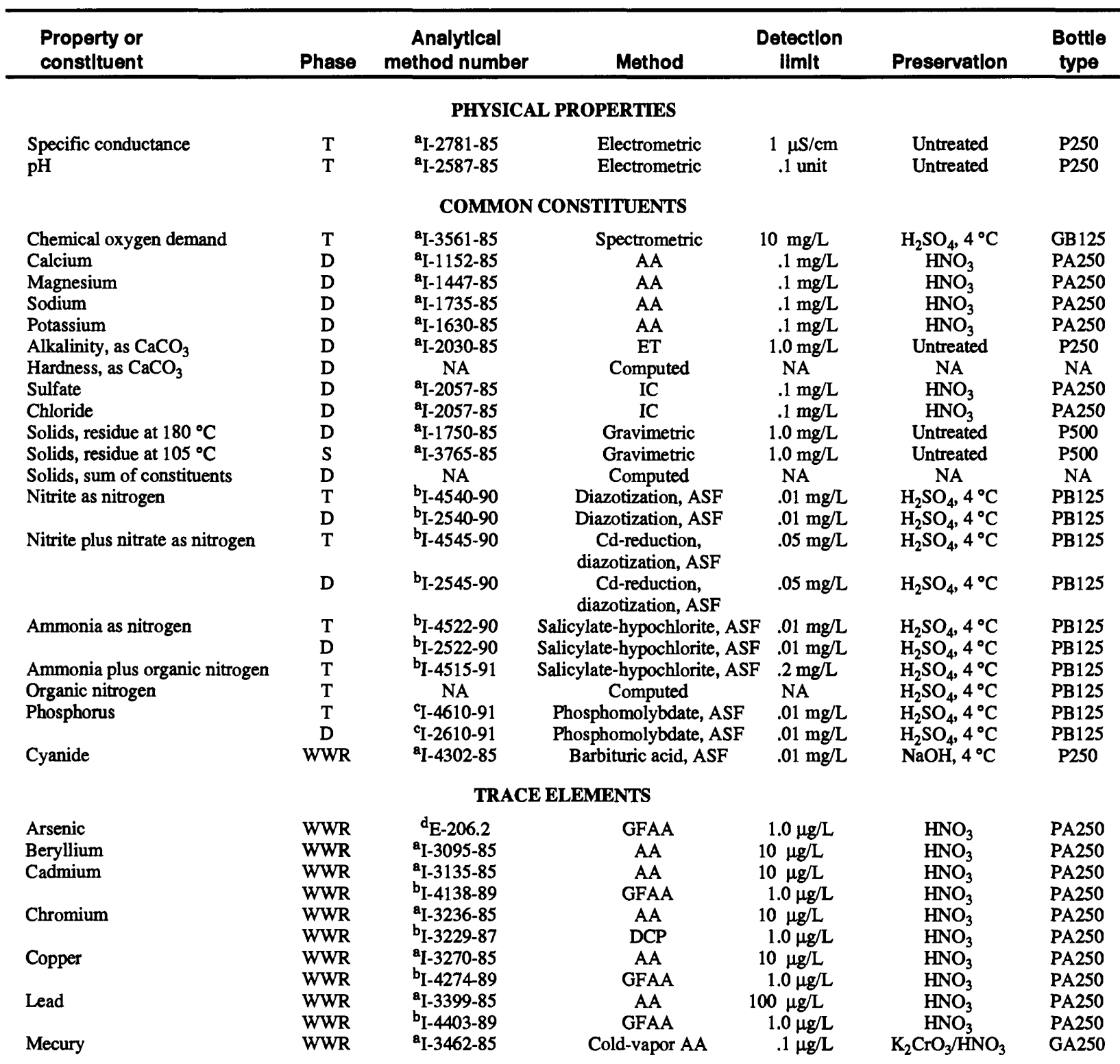


Table 2. Methods, detection limits, preservation, and bottle types used for determination of constituent concentrations at the U.S. Geological Survey, Arvada, Colorado-Continued

\begin{tabular}{|c|c|c|c|c|c|c|}
\hline $\begin{array}{l}\text { Property or } \\
\text { constituent }\end{array}$ & Phase & $\begin{array}{c}\text { Analytical } \\
\text { method number }\end{array}$ & Method & $\begin{array}{c}\text { Detection } \\
\text { iimit }\end{array}$ & Preservatlon & $\begin{array}{l}\text { Bottie } \\
\text { type }\end{array}$ \\
\hline \multicolumn{7}{|c|}{ TRACE ELEMENTS--Continued } \\
\hline $\begin{array}{l}\text { Nickel } \\
\text { Selenium } \\
\text { Silver } \\
\text { Zinc }\end{array}$ & $\begin{array}{l}\text { WWR } \\
\text { WWR } \\
\text { WWR } \\
\text { WWR } \\
\text { WWR }\end{array}$ & $\begin{array}{c}\mathrm{a}_{\mathrm{a}}-3499-85 \\
\mathrm{~b}_{\mathrm{I}}-4503-89 \\
{ }^{\mathrm{d}} \mathrm{E}-270.2 \\
{ }^{\mathrm{b}} \mathrm{I}-4724-89 \\
{ }^{\mathrm{a}} \mathrm{I}-3900-85\end{array}$ & $\begin{array}{c}\text { AA } \\
\text { GFAA } \\
\text { GFAA } \\
\text { GFAA } \\
\text { AA }\end{array}$ & $\begin{array}{c}100 \mu \mathrm{g} / \mathrm{L} \\
1.0 \mu \mathrm{g} / \mathrm{L} \\
1.0 \mu \mathrm{g} / \mathrm{L} \\
1.0 \mu \mathrm{g} / \mathrm{L} \\
10 \mu \mathrm{g} / \mathrm{L}\end{array}$ & $\begin{array}{l}\mathrm{HNO}_{3} \\
\mathrm{HNO}_{3} \\
\mathrm{HNO}_{3} \\
\mathrm{HNO}_{3} \\
\mathrm{HNO}_{3}\end{array}$ & $\begin{array}{l}\text { PA250 } \\
\text { PA250 } \\
\text { PA250 } \\
\text { PA250 } \\
\text { PA250 }\end{array}$ \\
\hline \multicolumn{7}{|c|}{ ORGANIC } \\
\hline $\begin{array}{l}\text { Organic carbon } \\
\text { Oils and grease } \\
\text { Phenols }^{f}\end{array}$ & $\begin{array}{l}T \\
T \\
T\end{array}$ & $\begin{array}{l}\text { eO-3100-83 } \\
\text { e }^{\mathrm{e}} \mathrm{O}-3108-83 \\
{ }^{\mathrm{O} O-3110-83}\end{array}$ & $\begin{array}{c}\text { Wet oxidation } \\
\text { Extraction gravimetric } \\
\text { Colorimetric }\end{array}$ & $\begin{array}{l}0.1 \mathrm{mg} / \mathrm{L} \\
1.0 \mathrm{mg} / \mathrm{L} \\
1.0 \mu \mathrm{g} / \mathrm{L}\end{array}$ & $\begin{array}{c}\mathrm{H}_{2} \mathrm{SO}_{4}, 4^{\circ} \mathrm{C} \\
\mathrm{H}_{2} \mathrm{SO}_{4} \\
\mathrm{H}_{3} \mathrm{PO}_{4} / \mathrm{CuSO}_{4}, 4^{\circ} \mathrm{C}\end{array}$ & $\begin{array}{l}\text { GB125 } \\
\text { GB1000 } \\
\text { GB1000 }\end{array}$ \\
\hline \multicolumn{7}{|c|}{ PESTICIDES } \\
\hline $\begin{array}{l}\text { Aldrin } \\
\text { Alpha BHC } \\
\text { Beta BHC } \\
\text { Delta BHC } \\
\text { Chlordane } \\
\text { cis-chlordane } \\
\text { trans-chlordane }\end{array}$ & $\begin{array}{l}\text { WWR } \\
\text { WWR } \\
\text { WWR } \\
\text { WWR } \\
\text { WWR } \\
\text { WWR }\end{array}$ & $\begin{array}{l}{ }^{8} E-608-91 \\
{ }^{8} E-608-91 \\
{ }^{8} E-608-91 \\
{ }^{8} E-608-91 \\
{ }^{8} E-608-91 \\
{ }^{8} E-608-91 \\
{ }^{8} E-608-91\end{array}$ & $\begin{array}{l}\text { GC/ECD } \\
\text { GC/ECD } \\
\text { GC/ECD } \\
\text { GC/ECD } \\
\text { GC/ECD } \\
\text { GC/ECD }\end{array}$ & $\begin{array}{l}0.04 \mu \mathrm{g} / \mathrm{L} \\
.3 \mu \mathrm{g} / \mathrm{L} \\
.03 \mu \mathrm{g} / \mathrm{L} \\
.09 \mu \mathrm{g} / \mathrm{L} \\
.1 \mu \mathrm{g} / \mathrm{L} \\
.1 \mu \mathrm{g} / \mathrm{L}\end{array}$ & $\begin{array}{l}4^{\circ} \mathrm{C} \\
4^{\circ} \mathrm{C} \\
4^{\circ} \mathrm{C} \\
4^{\circ} \mathrm{C} \\
4^{\circ} \mathrm{C} \\
4^{\circ} \mathrm{C}\end{array}$ & $\begin{array}{l}\text { GB1000 } \\
\text { GB1000 } \\
\text { GB1000 } \\
\text { GB1000 } \\
\text { GB1000 } \\
\text { GB1000 }\end{array}$ \\
\hline$p, p^{\prime}-\mathrm{DDD}$ & WWR & ${ }^{8} \mathrm{E}-608-91$ & $\mathrm{GC} / \mathrm{ECD}$ & $.1 \mu \mathrm{g} / \mathrm{L}$ & $4^{\circ} \mathrm{C}$ & GB1000 \\
\hline$p, p^{\prime}-\mathrm{DDE}$ & WWR & ${ }^{8} \mathrm{E}-608-91$ & GC/ECD & $.04 \mu \mathrm{g} / \mathrm{L}$ & $4^{\circ} \mathrm{C}$ & GB 1000 \\
\hline$p, p^{\prime}-\mathrm{DDT}$ & WWR & ${ }^{8} \mathrm{E}-608-91$ & GC/ECD & $.1 \mu \mathrm{g} / \mathrm{L}$ & $4^{\circ} \mathrm{C}$ & GB1000 \\
\hline Diazinon & WWR & ${ }^{8} \mathrm{E}-608-91$ & GC/ECD & $.1 \mu \mathrm{g} / \mathrm{L}$ & $4^{\circ} \mathrm{C}$ & GB1000 \\
\hline Dieldrin & WWR & ${ }^{8} \mathrm{E}-608-91$ & $\mathrm{GC} / \mathrm{ECD}$ & $.02 \mu \mathrm{g} / \mathrm{L}$ & $4^{\circ} \mathrm{C}$ & GB1000 \\
\hline Alpha-endosulfan & WWR & ${ }^{8} \mathrm{E}-608-91$ & $\mathrm{GC} / \mathrm{ECD}$ & $.1 \mu \mathrm{g} / \mathrm{L}$ & $4^{\circ} \mathrm{C}$ & GB1000 \\
\hline Beta-endosulfan & WWR & ${ }^{8} \mathrm{E}-608-91$ & $\mathrm{GC} / \mathrm{ECD}$ & $.04 \mu \mathrm{g} / \mathrm{L}$ & $4^{\circ} \mathrm{C}$ & GB1000 \\
\hline Endosulfan sulfate & WWR & ${ }^{8} \mathrm{E}-608-91$ & $\mathrm{GC} / \mathrm{ECD}$ & $.6 \mu \mathrm{g} / \mathrm{L}$ & $4^{\circ} \mathrm{C}$ & GB1000 \\
\hline Endrin & WWR & ${ }^{8} \mathrm{E}-608-91$ & $\mathrm{GC} / \mathrm{ECD}$ & $.06 \mu \mathrm{g} / \mathrm{L}$ & $4^{\circ} \mathrm{C}$ & GB1000 \\
\hline Endrin aldehyde & WWR & ${ }^{8} \mathrm{E}-608-91$ & $\mathrm{GC} / \mathrm{ECD}$ & $.2 \mu \mathrm{g} / \mathrm{L}$ & $4^{\circ} \mathrm{C}$ & GB1000 \\
\hline Heptachlor & WWR & ${ }^{8} \mathrm{E}-608-91$ & GC/ECD & $.03 \mu \mathrm{g} / \mathrm{L}$ & $4^{\circ} \mathrm{C}$ & GB1000 \\
\hline Heptachlor epoxide & WWR & ${ }^{8}-608-91$ & GC/ECD & $.8 \mu \mathrm{g} / \mathrm{L}$ & $4^{\circ} \mathrm{C}$ & GB 1000 \\
\hline Lindane & WWR & ${ }^{8} \mathrm{E}-608-91$ & GC/ECD & $.03 \mu \mathrm{g} / \mathrm{L}$ & $4^{\circ} \mathrm{C}$ & GB 1000 \\
\hline PCB, Aroclor 1016 & WWR & ${ }^{8} \mathrm{E}-608-91$ & GC/ECD & $.1 \mu \mathrm{g} / \mathrm{L}$ & $4^{\circ} \mathrm{C}$ & GB 1000 \\
\hline PCB, Aroclor 1221 & WWR & ${ }^{8} \mathrm{E}-608-91$ & GC/ECD & $1 \mu \mathrm{g} / \mathrm{L}$ & $4^{\circ} \mathrm{C}$ & GB 1000 \\
\hline PCB, Aroclor 1232 & WWR & ${ }^{8} \mathrm{E}-608-91$ & GC/ECD & $.1 \mu \mathrm{g} / \mathrm{L}$ & $4^{\circ} \mathrm{C}$ & GB 1000 \\
\hline PCB, Aroclor 1242 & WWR & ${ }^{8}$ E-608-91 & GC/ECD & $.1 \mu \mathrm{g} / \mathrm{L}$ & $4^{\circ} \mathrm{C}$ & GB 1000 \\
\hline PCB, Aroclor 1248 & WWR & ${ }^{8} \mathrm{E}-608-91$ & GC/ECD & $.1 \mu \mathrm{g} / \mathrm{L}$ & $4^{\circ} \mathrm{C}$ & GB1000 \\
\hline PCB, Aroclor 1254 & WWR & ${ }^{8} \mathrm{E}-608-91$ & $\mathrm{GC} / \mathrm{ECD}$ & $.1 \mu \mathrm{g} / \mathrm{L}$ & $4^{\circ} \mathrm{C}$ & GB1000 \\
\hline PCB, Aroclor 1260 & WWR & ${ }^{8} \mathrm{E}-608-91$ & GC/ECD & $.1 \mu \mathrm{g} / \mathrm{L}$ & $4^{\circ} \mathrm{C}$ & GB1000 \\
\hline Toxaphene & WWR & ${ }^{8} \mathrm{E}-608-91$ & GC/ECD & $2 \mu \mathrm{g} / \mathrm{L}$ & $4^{\circ} \mathrm{C}$ & GB1000 \\
\hline \multicolumn{7}{|c|}{$\begin{array}{l}\text { VOLATILE ORGANIC COMPOUNDS } \\
\text { Substituted Methane }\end{array}$} \\
\hline Bromomethane & WWR & ${ }^{h} \mathrm{E}-524.2$ & GC/MS & $0.2 \mu \mathrm{g} / \mathrm{L}$ & $\mathrm{HCl}, 4^{\circ} \mathrm{C}$ & GB40 \\
\hline Dibromomethane & WWR & ${ }^{\mathrm{h}} \mathrm{E}-524.2$ & GC/MS & $.2 \mu \mathrm{g} / \mathrm{L}$ & $\mathrm{HCl}, 4^{\circ} \mathrm{C}$ & GB40 \\
\hline Bromoform & WWR & ${ }^{\mathrm{h}} \mathrm{E}-524.2$ & GC/MS & $.2 \mu \mathrm{g} / \mathrm{L}$ & $\mathrm{HCl}, 4^{\circ} \mathrm{C}$ & GB40 \\
\hline Bromochloromethane & WWR & ${ }^{\mathrm{h}} \mathrm{E}-524.2$ & GC/MS & $.2 \mu \mathrm{g} / \mathrm{L}$ & $\mathrm{HCl}, 4^{\circ} \mathrm{C}$ & GB40 \\
\hline Dibromochloromethane & WWR & ${ }^{\mathrm{h}} \mathrm{E}-524.2$ & GC/MS & $.2 \mu \mathrm{g} / \mathrm{L}$ & $\mathrm{HCl}, 4^{\circ} \mathrm{C}$ & GB 40 \\
\hline Chloromethane & WWR & ${ }^{\mathrm{h}} \mathrm{E}-524.2$ & GC/MS & $.2 \mu \mathrm{g} / \mathrm{L}$ & $\mathrm{HCl}, 4^{\circ} \mathrm{C}$ & GB40 \\
\hline Dichloromethane & WWR & ${ }^{h} E-524.2$ & GC/MS & $.2 \mu \mathrm{g} / \mathrm{L}$ & $\mathrm{HCl}, 4^{\circ} \mathrm{C}$ & GB40 \\
\hline Trichloromethane & WWR & ${ }^{\mathrm{h}} \mathrm{E}-524.2$ & GC/MS & $.2 \mu \mathrm{g} / \mathrm{L}$ & $\mathrm{HCl}, 4^{\circ} \mathrm{C}$ & GB40 \\
\hline Tetrachloromethane & WWR & ${ }^{\mathrm{h}} \mathrm{E}-524.2$ & GC/MS & $.2 \mu \mathrm{g} / \mathrm{L}$ & $\mathrm{HCl}, 4^{\circ} \mathrm{C}$ & GB40 \\
\hline Dichlorobromomethane & WWR & ${ }^{h}$ E-524.2 & GC/MS & $.2 \mu \mathrm{g} / \mathrm{L}$ & $\mathrm{HCl}, 4^{\circ} \mathrm{C}$ & GB40 \\
\hline Dichlorodifluoromethane & WWR & ${ }^{\mathrm{h}} \mathrm{E}-524.2$ & GC/MS & $.2 \mu \mathrm{g} / \mathrm{L}$ & $\mathrm{HCl}, 4^{\circ} \mathrm{C}$ & GB 40 \\
\hline Trichlorofluoromethane & WWR & ${ }^{h} \mathrm{E}-524.2$ & GC/MS & $.2 \mu \mathrm{g} / \mathrm{L}$ & $\mathrm{HCl}, 4^{\circ} \mathrm{C}$ & GB40 \\
\hline \multicolumn{7}{|c|}{ Substituted Ethane } \\
\hline Chloroethane & WWR & ${ }^{h}{ }_{E-524.2}$ & GC/MS & $0.2 \mu \mathrm{g} / \mathrm{L}$ & $\mathrm{HCl}, 4^{\circ} \mathrm{C}$ & GB40 \\
\hline 1,2-Dibromoethane & WWR & ${ }^{\mathrm{h}} \mathrm{E}-524.2$ & GC/MS & $.2 \mu \mathrm{g} / \mathrm{L}$ & $\mathrm{HCl}, 4^{\circ} \mathrm{C}$ & GB40 \\
\hline 1,1-Dichloroethane & WWR & ${ }^{h} \mathrm{E}-524.2$ & GC/MS & $.2 \mu \mathrm{g} / \mathrm{L}$ & $\mathrm{HCl}, 4^{\circ} \mathrm{C}$ & GB40 \\
\hline 1,2-Dichloroethane & WWR & ${ }^{\mathrm{h}} \mathrm{E}-524.2$ & GC/MS & $.2 \mu \mathrm{g} / \mathrm{L}$ & $\mathrm{HCl}, 4^{\circ} \mathrm{C}$ & GB40 \\
\hline
\end{tabular}


Table 2. Methods, detection limits, preservation, and bottle types used for determination of constituent concentrations at the U.S. Geological Survey, Arvada, Colorado-Continued

\begin{tabular}{|c|c|c|c|c|c|c|}
\hline $\begin{array}{l}\text { Property or } \\
\text { constituent }\end{array}$ & Phase & $\begin{array}{c}\text { Analytlcal } \\
\text { method number }\end{array}$ & Method & $\begin{array}{c}\text { Detectlon } \\
\text { IImit }\end{array}$ & Preservation & $\begin{array}{c}\text { Bottle } \\
\text { type }\end{array}$ \\
\hline \multicolumn{7}{|c|}{$\begin{array}{l}\text { VOLATILE ORGANIC COMPOUNDS--Continued } \\
\text { Substituted Ethane--Continued }\end{array}$} \\
\hline $\begin{array}{l}\text { 1,1,1-Trichloroethane } \\
\text { 1,1,2-Trichloroethane } \\
\text { 1,1,1,2-Tetrachloroethane } \\
\text { 1,1,2,2-Tetrachloroethane } \\
\text { Trichlorotrifluoroethane }\end{array}$ & $\begin{array}{l}\text { WWR } \\
\text { WWR } \\
\text { WWR } \\
\text { WWR } \\
\text { WWR }\end{array}$ & $\begin{array}{l}{ }_{\mathrm{h}}^{\mathrm{h}} \mathrm{E}-524.2 \\
{ }_{\mathrm{h}} \mathrm{E}-524.2 \\
{ }_{\mathrm{h}}{ }_{\mathrm{E}}-524.2 \\
{ }^{\mathrm{h}_{\mathrm{C}}} \mathrm{E}-524.2 \\
{ }^{\mathrm{h}_{\mathrm{E}}} \mathrm{E}-524.2\end{array}$ & $\begin{array}{l}\text { GC/MS } \\
\text { GC/MS } \\
\text { GC/MS } \\
\text { GC/MS } \\
\text { GC/MS }\end{array}$ & $\begin{array}{l}0.2 \mu \mathrm{g} / \mathrm{L} \\
.2 \mu \mathrm{g} / \mathrm{L} \\
.2 \mu \mathrm{g} / \mathrm{L} \\
.2 \mu \mathrm{g} / \mathrm{L} \\
.5 \mu \mathrm{g} / \mathrm{L}\end{array}$ & $\begin{array}{l}\mathrm{HCl}, 4^{\circ} \mathrm{C} \\
\mathrm{HCl}, 4^{\circ} \mathrm{C} \\
\mathrm{HCl}, 4^{\circ} \mathrm{C} \\
\mathrm{HCl}, 4^{\circ} \mathrm{C} \\
\mathrm{HCl}, 4^{\circ} \mathrm{C}\end{array}$ & $\begin{array}{l}\text { GB40 } \\
\text { GB40 } \\
\text { GB40 } \\
\text { GB40 } \\
\text { GB40 }\end{array}$ \\
\hline \multicolumn{7}{|c|}{ Substituted Ethene } \\
\hline $\begin{array}{l}\text { Chloroethene } \\
\text { 1,1-Dichloroethene } \\
\text { cis-1,2-Dichloroethene } \\
\text { trans-1,2-Dichloroethene } \\
\text { 1,1,2-Trichloroethene } \\
\text { 1,1,2,2-Tetrachloroethene }\end{array}$ & $\begin{array}{l}\text { WWR } \\
\text { WWR } \\
\text { WWR } \\
\text { WWR } \\
\text { WWR } \\
\text { WWR }\end{array}$ & $\begin{array}{l}{ }^{\mathrm{h}} \mathrm{E}-524.2 \\
{ }^{\mathrm{h}} \mathrm{E}-524.2 \\
{ }^{\mathrm{h}} \mathrm{E}-524.2 \\
{ }^{\mathrm{h}} \mathrm{E}-524.2 \\
{ }^{\mathrm{h}} \mathrm{E}-524.2 \\
{ }^{\mathrm{h}} \mathrm{E}-524.2\end{array}$ & $\begin{array}{l}\text { GC/MS } \\
\text { GC/MS } \\
\text { GC/MS } \\
\text { GC/MS } \\
\text { GC/MS } \\
\text { GC/MS }\end{array}$ & $\begin{array}{l}0.2 \mu \mathrm{g} / \mathrm{L} \\
.2 \mu \mathrm{g} / \mathrm{L} \\
.2 \mu \mathrm{g} / \mathrm{L} \\
.2 \mu \mathrm{g} / \mathrm{L} \\
.2 \mu \mathrm{g} / \mathrm{L} \\
.2 \mu \mathrm{g} / \mathrm{L}\end{array}$ & $\begin{array}{l}\mathrm{HCl}, 4^{\circ} \mathrm{C} \\
\mathrm{HCl}, 4^{\circ} \mathrm{C} \\
\mathrm{HCl}, 4^{\circ} \mathrm{C} \\
\mathrm{HCl}, 4^{\circ} \mathrm{C} \\
\mathrm{HCl}, 4^{\circ} \mathrm{C} \\
\mathrm{HCl}, 4^{\circ} \mathrm{C}\end{array}$ & $\begin{array}{l}\text { GB40 } \\
\text { GB40 } \\
\text { GB40 } \\
\text { GB40 } \\
\text { GB40 } \\
\text { GB40 }\end{array}$ \\
\hline \multicolumn{7}{|c|}{ Substituted Propane } \\
\hline $\begin{array}{l}\text { 1,2-Dichloropropane } \\
\text { 1,3-Dichloropropane } \\
\text { 2,2-Dichloropropane } \\
\text { 1,2,3-Trichloropropane } \\
\text { 1,2-Dibromo-3-chloropropane }\end{array}$ & $\begin{array}{l}\text { WWR } \\
\text { WWR } \\
\text { WWR } \\
\text { WWR } \\
\text { WWR }\end{array}$ & $\begin{array}{l}{ }^{\mathrm{h}} \mathrm{E}-524.2 \\
{ }_{\mathrm{h}} \mathrm{E}-524.2 \\
{ }_{\mathrm{h}} \mathrm{E}-524.2 \\
{ }^{\mathrm{h}} \mathrm{E}-524.2 \\
{ }^{{ }^{h}} \mathrm{E}-524.2\end{array}$ & $\begin{array}{l}\text { GC/MS } \\
\text { GC/MS } \\
\text { GC/MS } \\
\text { GC/MS } \\
\text { GC/MS }\end{array}$ & $\begin{array}{c}0.2 \mu \mathrm{g} / \mathrm{L} \\
.2 \mu \mathrm{g} / \mathrm{L} \\
.2 \mu \mathrm{g} / \mathrm{L} \\
.2 \mu \mathrm{g} / \mathrm{L} \\
1.0 \mu \mathrm{g} / \mathrm{L}\end{array}$ & $\begin{array}{l}\mathrm{HCl}, 4^{\circ} \mathrm{C} \\
\mathrm{HCl}, 4^{\circ} \mathrm{C} \\
\mathrm{HCl}, 4^{\circ} \mathrm{C} \\
\mathrm{HCl}, 4^{\circ} \mathrm{C} \\
\mathrm{HCl}, 4^{\circ} \mathrm{C}\end{array}$ & $\begin{array}{l}\text { GB40 } \\
\text { GB40 } \\
\text { GB40 } \\
\text { GB40 } \\
\text { GB40 }\end{array}$ \\
\hline \multicolumn{7}{|c|}{ Substituted Propene } \\
\hline $\begin{array}{l}\text { 1,1-Dichloropropene } \\
\text { cis-1,3-Dichloropropene } \\
\text { trans-1,3-Dichloropropene }\end{array}$ & $\begin{array}{l}\text { WWR } \\
\text { WWR } \\
\text { WWR }\end{array}$ & $\begin{array}{l}{ }^{\mathrm{h}} \mathrm{E}-524.2 \\
{ }^{\mathrm{h}} \mathrm{E}-524.2 \\
{ }^{\mathrm{h}} \mathrm{E}-524.2\end{array}$ & $\begin{array}{l}\text { GC/MS } \\
\text { GC/MS } \\
\text { GC/MS }\end{array}$ & $\begin{array}{c}0.2 \mu \mathrm{g} / \mathrm{L} \\
.2 \mu \mathrm{g} / \mathrm{L} \\
.2 \mu \mathrm{g} / \mathrm{L}\end{array}$ & $\begin{array}{l}\mathrm{HCl}, 4^{\circ} \mathrm{C} \\
\mathrm{HCl}, 4^{\circ} \mathrm{C} \\
\mathrm{HCl}, 4^{\circ} \mathrm{C}\end{array}$ & $\begin{array}{l}\text { GB40 } \\
\text { GB40 } \\
\text { GB40 }\end{array}$ \\
\hline \multicolumn{7}{|c|}{ Substituted Butene } \\
\hline Hexachlorobutadiene & WWR & ${ }^{\mathrm{h}} \mathrm{E}-524.2$ & $\mathrm{GC} / \mathrm{MS}$ & $0.2 \mu \mathrm{g} / \mathrm{L}$ & $\mathrm{HCl}, 4^{\circ} \mathrm{C}$ & GB40 \\
\hline \multicolumn{7}{|c|}{ Benzene Derivative } \\
\hline $\begin{array}{l}\text { Benzene } \\
\text { Bromobenzene } \\
\text { Chlorobenzene } \\
\text { 1,2-Dichlorobenzene } \\
\text { 1,3-Dichlorobenzene } \\
\text { 1,4-Dichlorobenzene } \\
\text { 1,2,3-Trichlorobenzene } \\
\text { 1,2,4-Trichlorobenzene } \\
\text { Xylenes, total } \\
\text { 1,2,4-Trimethylbenzene } \\
\text { 1,3,5-Trimethylbenzene } \\
\text { Ethylbenzene } \\
n \text {-Propylbenzene } \\
n \text {-Butylbenzene } \\
\text { (1-Methylethyl)benzene } \\
\text { (1,1-Dimethylethyl)benzene } \\
\text { (1-Methylpropyl)benzene } \\
\text { Styrene } \\
\text { Toluene } \\
\text { 2-Chlorotoluene } \\
\text { 4-Chlorotoluene } \\
\text { p-Isopropyltoluene } \\
\text { Naphthalene }\end{array}$ & $\begin{array}{l}\text { WWR } \\
\text { WWR } \\
\text { WWR } \\
\text { WWR } \\
\text { WWR } \\
\text { WWR } \\
\text { WWR } \\
\text { WWR } \\
\text { WWR } \\
\text { WWR } \\
\text { WWR } \\
\text { WWR } \\
\text { WWR } \\
\text { WWR } \\
\text { WWR } \\
\text { WWR } \\
\text { WWR } \\
\text { WWR } \\
\text { WWR } \\
\text { WWR } \\
\text { WWR } \\
\text { WWR } \\
\text { WWR }\end{array}$ & $\begin{array}{l}{ }^{\mathrm{h}} \mathrm{E}-524.2 \\
{ }^{\mathrm{h}} \mathrm{E}-524.2 \\
{ }^{\mathrm{h}} \mathrm{E}-524.2 \\
{ }^{\mathrm{h}} \mathrm{E}-524.2 \\
{ }^{\mathrm{h}} \mathrm{E}-524.2 \\
{ }^{\mathrm{h}} \mathrm{E}-524.2 \\
{ }^{\mathrm{h}} \mathrm{E}-524.2 \\
{ }^{\mathrm{h}} \mathrm{E}-524.2 \\
\mathrm{~h}_{\mathrm{h}} \mathrm{E}-524.2 \\
{ }^{\mathrm{h}} \mathrm{E}-524.2 \\
{ }^{\mathrm{h}} \mathrm{E}-524.2 \\
{ }^{\mathrm{h}} \mathrm{E}-524.2 \\
{ }^{\mathrm{h}} \mathrm{E}-524.2 \\
{ }^{\mathrm{h}} \mathrm{E}-524.2 \\
{ }^{\mathrm{h}} \mathrm{E}-524.2 \\
{ }^{\mathrm{h}} \mathrm{E}-524.2 \\
{ }^{\mathrm{h}} \mathrm{E}-524.2 \\
{ }^{\mathrm{h}} \mathrm{E}-524.2 \\
{ }^{\mathrm{h}} \mathrm{E}-524.2 \\
{ }^{\mathrm{h}} \mathrm{E}-524.2 \\
{ }^{\mathrm{h}} \mathrm{E}-524.2 \\
{ }^{\mathrm{h}} \mathrm{E}-524.2 \\
{ }^{\mathrm{h}} \mathrm{E}-524.2\end{array}$ & $\begin{array}{l}\text { GC/MS } \\
\text { GC/MS } \\
\text { GC/MS } \\
\text { GC/MS } \\
\text { GC/MS } \\
\text { GC/MS } \\
\text { GC/MS } \\
\text { GC/MS } \\
\text { GC/MS } \\
\text { GC/MS } \\
\text { GC/MS } \\
\text { GC/MS } \\
\text { GC/MS } \\
\text { GC/MS } \\
\text { GC/MS } \\
\text { GC/MS } \\
\text { GC/MS } \\
\text { GC/MS } \\
\text { GC/MS } \\
\text { GC/MS } \\
\text { GC/MS } \\
\text { GC/MS } \\
\text { GC/MS }\end{array}$ & $\begin{array}{l}0.2 \mu \mathrm{g} / \mathrm{L} \\
.2 \mu \mathrm{g} / \mathrm{L} \\
.2 \mu \mathrm{g} / \mathrm{L} \\
.2 \mu \mathrm{g} / \mathrm{L} \\
.2 \mu \mathrm{g} / \mathrm{L} \\
.2 \mu \mathrm{g} / \mathrm{L} \\
.2 \mu \mathrm{g} / \mathrm{L} \\
.2 \mu \mathrm{g} / \mathrm{L} \\
.2 \mu \mathrm{g} / \mathrm{L} \\
.2 \mu \mathrm{g} / \mathrm{L} \\
.2 \mu \mathrm{g} / \mathrm{L} \\
.2 \mu \mathrm{g} / \mathrm{L} \\
.2 \mu \mathrm{g} / \mathrm{L} \\
.2 \mu \mathrm{g} / \mathrm{L} \\
.2 \mu \mathrm{g} / \mathrm{L} \\
.2 \mu \mathrm{g} / \mathrm{L} \\
.2 \mu \mathrm{g} / \mathrm{L} \\
.2 \mu \mathrm{g} / \mathrm{L} \\
.2 \mu \mathrm{g} / \mathrm{L} \\
.2 \mu \mathrm{g} / \mathrm{L} \\
.2 \mu \mathrm{g} / \mathrm{L} \\
.2 \mu \mathrm{g} / \mathrm{L} \\
.2 \mu \mathrm{g} / \mathrm{L}\end{array}$ & $\begin{array}{l}\mathrm{HCl}, 4^{\circ} \mathrm{C} \\
\mathrm{HCl}, 4^{\circ} \mathrm{C} \\
\mathrm{HCl}, 4^{\circ} \mathrm{C} \\
\mathrm{HCl}, 4^{\circ} \mathrm{C} \\
\mathrm{HCl}, 4^{\circ} \mathrm{C} \\
\mathrm{HCl}, 4^{\circ} \mathrm{C} \\
\mathrm{HCl}, 4^{\circ} \mathrm{C} \\
\mathrm{HCl}, 4^{\circ} \mathrm{C} \\
\mathrm{HCl}, 4^{\circ} \mathrm{C} \\
\mathrm{HCl}, 4^{\circ} \mathrm{C} \\
\mathrm{HCl}, 4^{\circ} \mathrm{C} \\
\mathrm{HCl}, 4^{\circ} \mathrm{C} \\
\mathrm{HCl}, 4^{\circ} \mathrm{C} \\
\mathrm{HCl}, 4^{\circ} \mathrm{C} \\
\mathrm{HCl}, 4^{\circ} \mathrm{C} \\
\mathrm{HCl}, 4^{\circ} \mathrm{C} \\
\mathrm{HCl}, 4^{\circ} \mathrm{C} \\
\mathrm{HCl}, 4^{\circ} \mathrm{C} \\
\mathrm{HCl}, 4^{\circ} \mathrm{C} \\
\mathrm{HCl}, 4^{\circ} \mathrm{C} \\
\mathrm{HCl}, 4^{\circ} \mathrm{C} \\
\mathrm{HCl}, 4^{\circ} \mathrm{C} \\
\mathrm{HCl}, 4^{\circ} \mathrm{C}\end{array}$ & $\begin{array}{l}\text { GB40 } \\
\text { GB40 } \\
\text { GB40 } \\
\text { GB40 } \\
\text { GB40 } \\
\text { GB40 } \\
\text { GB40 } \\
\text { GB40 } \\
\text { GB40 } \\
\text { GB40 } \\
\text { GB40 } \\
\text { GB40 } \\
\text { GB40 } \\
\text { GB40 } \\
\text { GB40 } \\
\text { GB40 } \\
\text { GB40 } \\
\text { GB40 } \\
\text { GB40 } \\
\text { GB40 } \\
\text { GB40 } \\
\text { GB40 } \\
\text { GB40 }\end{array}$ \\
\hline \multicolumn{7}{|c|}{ Ether } \\
\hline $\begin{array}{l}\text { 2-Chloroethylvinyl ether } \\
\text { Methyl-tertiary-butyl ether }\end{array}$ & $\begin{array}{l}\text { WWR } \\
\text { WWR }\end{array}$ & $\begin{array}{l}\mathrm{h}_{\mathrm{E}}-524.2 \\
{ }^{\mathrm{h}} \mathrm{E}-524.2\end{array}$ & $\begin{array}{l}\text { GC/MS } \\
\text { GC/MS }\end{array}$ & $\begin{array}{l}1.0 \mu \mathrm{g} / \mathrm{L} \\
1.0 \mu \mathrm{g} / \mathrm{L}\end{array}$ & $\begin{array}{l}\mathrm{HCl}, 4^{\circ} \mathrm{C} \\
\mathrm{HCl}, 4^{\circ} \mathrm{C}\end{array}$ & $\begin{array}{l}\text { GB40 } \\
\text { GB40 }\end{array}$ \\
\hline
\end{tabular}


Table 2. Methods, detection limits, preservation, and bottle types used for determination of constituent concentrations at the U.S. Geological Survey, Arvada, Colorado-Continued

\begin{tabular}{|c|c|c|c|c|c|c|}
\hline $\begin{array}{l}\text { Property or } \\
\text { constltuent }\end{array}$ & Phase & $\begin{array}{l}\text { Analytical } \\
\text { method number }\end{array}$ & Method & $\begin{array}{l}\text { Detection } \\
\text { Ilmit }\end{array}$ & Preservation & $\begin{array}{c}\text { Bottle } \\
\text { type }\end{array}$ \\
\hline \multicolumn{7}{|c|}{$\begin{array}{l}\text { VOLATILE ORGANIC COMPOUNDS--Continued } \\
\text { Aldehyde }\end{array}$} \\
\hline Acrolein & WWR & ${ }^{\mathrm{h}} \mathrm{E}-524.2$ & GC/MS & $20 \mu g / L$ & $\mathrm{HCl}, 4^{\circ} \mathrm{C}$ & GB40 \\
\hline \multicolumn{7}{|c|}{ Nitrile } \\
\hline Acrylonitrile & WWR & ${ }^{\mathrm{h}} \mathrm{E}-524.2$ & GC/MS & $20 \mu \mathrm{g} / \mathrm{L}$ & $\mathrm{HCl}, 4^{\circ} \mathrm{C}$ & GB40 \\
\hline \multicolumn{7}{|c|}{$\begin{array}{l}\text { ACIDIC, BASIC, AND NEUTRAL SEMI-VOLATILE ORGANIC COMPOUNDS } \\
\text { Substituted Benzene }\end{array}$} \\
\hline $\begin{array}{l}\text { 1,2-Dichlorobenzene } \\
\text { 1,3-Dichlorobenzene } \\
\text { 1,4-Dichlorobenzene } \\
\text { 1,2,4-Trichlorobenzene } \\
\text { Hexachlorobenzene } \\
\text { Nitrobenzene } \\
\text { 2,4-Dinitrotoluene } \\
\text { 2,6-Dinitrotoluene }\end{array}$ & $\begin{array}{l}\text { WWR } \\
\text { WWR } \\
\text { WWR } \\
\text { WWR } \\
\text { WWR } \\
\text { WWR } \\
\text { WWR } \\
\text { WWR }\end{array}$ & $\begin{array}{l}{ }^{b} O-3116-87 \\
{ }^{b} O-3116-87 \\
{ }^{b} O-3116-87 \\
{ }^{b} O-3116-87 \\
{ }^{b} O-3116-87 \\
{ }^{b} O-3116-87 \\
{ }^{b} O-3116-87 \\
{ }^{b} O-3116-87\end{array}$ & $\begin{array}{l}\text { GC/MS } \\
\text { GC/MS } \\
\text { GC/MS } \\
\text { GC/MS } \\
\text { GC/MS } \\
\text { GC/MS } \\
\text { GC/MS } \\
\text { GC/MS }\end{array}$ & $\begin{array}{l}5 \mu \mathrm{g} / \mathrm{L} \\
5 \mu \mathrm{g} / \mathrm{L} \\
5 \mu \mathrm{g} / \mathrm{L} \\
5 \mu \mathrm{g} / \mathrm{L} \\
5 \mu \mathrm{g} / \mathrm{L} \\
5 \mu \mathrm{g} / \mathrm{L} \\
5 \mu \mathrm{g} / \mathrm{L} \\
5 \mu \mathrm{g} / \mathrm{L}\end{array}$ & $\begin{array}{l}4^{\circ} \mathrm{C} \\
4^{\circ} \mathrm{C} \\
4^{\circ} \mathrm{C} \\
4^{\circ} \mathrm{C} \\
4^{\circ} \mathrm{C} \\
4^{\circ} \mathrm{C} \\
4^{\circ} \mathrm{C} \\
4^{\circ} \mathrm{C}\end{array}$ & $\begin{array}{l}\text { GB1000 } \\
\text { GB1000 } \\
\text { GB1000 } \\
\text { GB1000 } \\
\text { GB1000 } \\
\text { GB1000 } \\
\text { GB1000 } \\
\text { GB1000 }\end{array}$ \\
\hline \multicolumn{7}{|c|}{ Substituted Phenol } \\
\hline $\begin{array}{l}\text { Phenol } \\
\text { 2-Chlorophenol } \\
\text { 2-Nitrophenol } \\
\text { 4-Nitrophenol } \\
\text { 2,4-Dichlorophenol } \\
\text { 2,4-Dimethylphenol } \\
\text { 2,4-Dimitrophenol } \\
\text { 4-Chloro-3-methylphenol } \\
\text { 2,4,6-Trichlorophenol } \\
\text { 4-Methyl-4,6-dinitrophenol } \\
\text { Pentachlorophenol }\end{array}$ & $\begin{array}{l}\text { WWR } \\
\text { WWR } \\
\text { WWR } \\
\text { WWR } \\
\text { WWR } \\
\text { WWR } \\
\text { WWR } \\
\text { WWR } \\
\text { WWR } \\
\text { WWR } \\
\text { WWR }\end{array}$ & $\begin{array}{l}{ }^{b} \mathrm{O}-3116-87 \\
{ }^{b} \mathrm{O}-3116-87 \\
{ }^{b} \mathrm{O}-3116-87 \\
{ }^{\mathrm{b}} \mathrm{O}-3116-87 \\
{ }^{\mathrm{b}} \mathrm{O}-3116-87 \\
{ }^{\mathrm{b}} \mathrm{O}-3116-87 \\
{ }^{\mathrm{b}} \mathrm{O}-3116-87 \\
{ }^{\mathrm{b}} \mathrm{O}-3116-87 \\
{ }^{\mathrm{b}} \mathrm{O}-3116-87 \\
{ }^{\mathrm{b}} \mathrm{O}-3116-87 \\
{ }^{\mathrm{b}} \mathrm{O}-3116-87\end{array}$ & $\begin{array}{l}\text { GC/MS } \\
\text { GC/MS } \\
\text { GC/MS } \\
\text { GC/MS } \\
\text { GC/MS } \\
\text { GC/MS } \\
\text { GC/MS } \\
\text { GC/MS } \\
\text { GC/MS } \\
\text { GC/MS } \\
\text { GC/MS }\end{array}$ & $\begin{array}{c}5 \mu \mathrm{g} / \mathrm{L} \\
5 \mu \mathrm{g} / \mathrm{L} \\
5 \mu \mathrm{g} / \mathrm{L} \\
30 \mu \mathrm{g} / \mathrm{L} \\
5 \mu \mathrm{g} / \mathrm{L} \\
5 \mu \mathrm{g} / \mathrm{L} \\
20 \mu \mathrm{g} / \mathrm{L} \\
30 \mu \mathrm{g} / \mathrm{L} \\
20 \mu \mathrm{g} / \mathrm{L} \\
30 \mu \mathrm{g} / \mathrm{L} \\
30 \mu \mathrm{g} / \mathrm{L}\end{array}$ & $\begin{array}{l}4{ }^{\circ} \mathrm{C} \\
4^{\circ} \mathrm{C} \\
4^{\circ} \mathrm{C} \\
4^{\circ} \mathrm{C} \\
4^{\circ} \mathrm{C} \\
4^{\circ} \mathrm{C} \\
4^{\circ} \mathrm{C} \\
4^{\circ} \mathrm{C} \\
4^{\circ} \mathrm{C} \\
4^{\circ} \mathrm{C} \\
4^{\circ} \mathrm{C}\end{array}$ & $\begin{array}{l}\text { GB1000 } \\
\text { GB1000 } \\
\text { GB1000 } \\
\text { GB1000 } \\
\text { GB1000 } \\
\text { GB1000 } \\
\text { GB1000 } \\
\text { GB1000 } \\
\text { GB1000 } \\
\text { GB1000 } \\
\text { GB1000 }\end{array}$ \\
\hline \multicolumn{7}{|c|}{ Polycyclic Aromatic Hydrocarbon } \\
\hline $\begin{array}{l}\text { Naphthalene } \\
\text { Acenaphthylene } \\
\text { Acenaphthene } \\
\text { Fluorene } \\
\text { Anthracene } \\
\text { Phenanthrene } \\
\text { Fluoranthene } \\
\text { Pyrene } \\
\text { Benzo[a]anthracene } \\
\text { Chrysene } \\
\text { Benzo[a]pyrene } \\
\text { Benzo }[b] \text { fluoranthene } \\
\text { Benzo }[k] \text { fluoranthene } \\
\text { Benzo[g,h,i]perylene } \\
\text { Indeno }[1,2,3-c d] \text { pyrene } \\
\text { Dibenzo[a,h]anthracene }\end{array}$ & $\begin{array}{l}\text { WWR } \\
\text { WWR } \\
\text { WWR } \\
\text { WWR } \\
\text { WWR } \\
\text { WWR } \\
\text { WWR } \\
\text { WWR } \\
\text { WWR } \\
\text { WWR } \\
\text { WWR } \\
\text { WWR } \\
\text { WWR } \\
\text { WWR } \\
\text { WWR } \\
\text { WWR }\end{array}$ & $\begin{array}{l}{ }^{b} O-3116-87 \\
{ }^{b} O-3116-87 \\
{ }^{b} O-3116-87 \\
{ }^{b} O-3116-87 \\
{ }^{b} O-3116-87 \\
{ }^{b} O-3116-87 \\
{ }^{b} O-3116-87 \\
{ }^{b} O-3116-87 \\
{ }^{b} O-3116-87 \\
{ }^{b} O-3116-87 \\
{ }^{b} O-3116-87 \\
{ }^{b} O-3116-87 \\
{ }^{b} O-3116-87 \\
{ }^{b} O-3116-87 \\
{ }^{b} O-3116-87 \\
{ }^{b} O-3116-87\end{array}$ & $\begin{array}{l}\text { GC/MS } \\
\text { GC/MS } \\
\text { GC/MS } \\
\text { GC/MS } \\
\text { GC/MS } \\
\text { GC/MS } \\
\text { GC/MS } \\
\text { GC/MS } \\
\text { GC/MS } \\
\text { GC/MS } \\
\text { GC/MS } \\
\text { GC/MS } \\
\text { GC/MS } \\
\text { GC/MS } \\
\text { GC/MS } \\
\text { GC/MS }\end{array}$ & $\begin{array}{c}5 \mu \mathrm{g} / \mathrm{L} \\
5 \mu \mathrm{g} / \mathrm{L} \\
5 \mu \mathrm{g} / \mathrm{L} \\
5 \mu \mathrm{g} / \mathrm{L} \\
5 \mu \mathrm{g} / \mathrm{L} \\
5 \mu \mathrm{g} / \mathrm{L} \\
5 \mu \mathrm{g} / \mathrm{L} \\
5 \mu \mathrm{g} / \mathrm{L} \\
10 \mu \mathrm{g} / \mathrm{L} \\
10 \mu \mathrm{g} / \mathrm{L} \\
10 \mu \mathrm{g} / \mathrm{L} \\
10 \mu \mathrm{g} / \mathrm{L} \\
10 \mu \mathrm{g} / \mathrm{L} \\
10 \mu \mathrm{g} / \mathrm{L} \\
10 \mu \mathrm{g} / \mathrm{L} \\
10 \mu \mathrm{g} / \mathrm{L}\end{array}$ & $\begin{array}{l}4{ }^{\circ} \mathrm{C} \\
4^{\circ} \mathrm{C} \\
4^{\circ} \mathrm{C} \\
4^{\circ} \mathrm{C} \\
4^{\circ} \mathrm{C} \\
4^{\circ} \mathrm{C} \\
4^{\circ} \mathrm{C} \\
4^{\circ} \mathrm{C} \\
4^{\circ} \mathrm{C} \\
4^{\circ} \mathrm{C} \\
4^{\circ} \mathrm{C} \\
4^{\circ} \mathrm{C} \\
4^{\circ} \mathrm{C} \\
4^{\circ} \mathrm{C} \\
4^{\circ} \mathrm{C} \\
4^{\circ} \mathrm{C}\end{array}$ & $\begin{array}{l}\text { GB1000 } \\
\text { GB1000 } \\
\text { GB1000 } \\
\text { GB1000 } \\
\text { GB1000 } \\
\text { GB1000 } \\
\text { GB1000 } \\
\text { GB1000 } \\
\text { GB1000 } \\
\text { GB1000 } \\
\text { GB1000 } \\
\text { GB1000 } \\
\text { GB1000 } \\
\text { GB1000 } \\
\text { GB1000 } \\
\text { GB1000 }\end{array}$ \\
\hline \multicolumn{7}{|c|}{ Phthalic Acid Ester, $n$-Nitroso Compound, Isophorone, and 1,2-diphenylhydrazine } \\
\hline $\begin{array}{l}\text { Dimethyl phthalate } \\
\text { Diethyl phthalate } \\
\text { Di-n-butyl phthalate } \\
n \text {-Butylbenzyl phthalate } \\
\text { Di-n-octyl phthalate } \\
\text { Di-2-ethylhexyl phthalate } \\
n \text {-Nitrosodimethylamine } \\
n \text {-Nitrosodi-n-propylamine } \\
n \text {-Nitrosodiphenylamine } \\
\text { Isophorone } \\
\text { 1,2-Diphenylhydrazine }\end{array}$ & $\begin{array}{l}\text { WWR } \\
\text { WWR } \\
\text { WWR } \\
\text { WWR } \\
\text { WWR } \\
\text { WWR } \\
\text { WWR } \\
\text { WWR } \\
\text { WWR } \\
\text { WWR } \\
\text { WWR }\end{array}$ & $\begin{array}{l}{ }^{b} \mathrm{~b}-3116-87 \\
{ }^{b} \mathrm{~b}-3116-87 \\
{ }^{\mathrm{b}} \mathrm{O}-3116-87 \\
{ }^{\mathrm{b}} \mathrm{O}-3116-87 \\
{ }^{\mathrm{b}} \mathrm{O}-3116-87 \\
{ }^{\mathrm{b}} \mathrm{O}-3116-87 \\
{ }^{\mathrm{b}} \mathrm{O}-3116-87 \\
{ }^{\mathrm{b}} \mathrm{O}-3116-87 \\
{ }^{\mathrm{b}} \mathrm{O}-3116-87 \\
{ }^{\mathrm{b}} \mathrm{O}-3116-87 \\
{ }^{\mathrm{b}} \mathrm{O}-3116-87\end{array}$ & $\begin{array}{l}\text { GC/MS } \\
\text { GC/MS } \\
\text { GC/MS } \\
\text { GC/MS } \\
\text { GC/MS } \\
\text { GC/MS } \\
\text { GC/MS } \\
\text { GC/MS } \\
\text { GC/MS } \\
\text { GC/MS } \\
\text { GC/MS }\end{array}$ & $\begin{array}{c}5 \mu \mathrm{g} / \mathrm{L} \\
5 \mu \mathrm{g} / \mathrm{L} \\
5 \mu \mathrm{g} / \mathrm{L} \\
5 \mu \mathrm{g} / \mathrm{L} \\
10 \mu \mathrm{g} / \mathrm{L} \\
5 \mu \mathrm{g} / \mathrm{L} \\
5 \mu \mathrm{g} / \mathrm{L} \\
5 \mu \mathrm{g} / \mathrm{L} \\
5 \mu \mathrm{g} / \mathrm{L} \\
5 \mu \mathrm{g} / \mathrm{L} \\
5 \mu \mathrm{g} / \mathrm{L}\end{array}$ & $\begin{array}{l}4{ }^{\circ} \mathrm{C} \\
4{ }^{\circ} \mathrm{C} \\
4^{\circ} \mathrm{C} \\
4^{\circ} \mathrm{C} \\
4^{\circ} \mathrm{C} \\
4^{\circ} \mathrm{C} \\
4^{\circ} \mathrm{C} \\
4^{\circ} \mathrm{C} \\
4^{\circ} \mathrm{C} \\
4^{\circ} \mathrm{C} \\
4^{\circ} \mathrm{C}\end{array}$ & $\begin{array}{l}\text { GB1000 } \\
\text { GB1000 } \\
\text { GB1000 } \\
\text { GB1000 } \\
\text { GB1000 } \\
\text { GB1000 } \\
\text { GB1000 } \\
\text { GB1000 } \\
\text { GB1000 } \\
\text { GB1000 } \\
\text { GB1000 }\end{array}$ \\
\hline
\end{tabular}


Table 2. Methods, detection limits, preservation, and bottle types used for determination of constituent concentrations at the U.S. Geological Survey, Arvada, Colorado-Continued

\begin{tabular}{|c|c|c|c|c|c|c|}
\hline $\begin{array}{l}\text { Property or } \\
\text { constituent }\end{array}$ & Phase & $\begin{array}{l}\text { Analytlcal } \\
\text { method number }\end{array}$ & Methód & $\begin{array}{l}\text { Detectlon } \\
\text { limit }\end{array}$ & Preservation & $\begin{array}{c}\text { Bottle } \\
\text { type }\end{array}$ \\
\hline \multicolumn{7}{|c|}{$\begin{array}{l}\text { ACIDIC, BASIC, AND NEUTRAL SEMI-VOLATILE ORGANIC COMPOUNDS--Continued } \\
\text { Halogenated Compound }\end{array}$} \\
\hline $\begin{array}{l}\text { Hexachloroethane } \\
\text { bis(2-Chloroethyl) ether } \\
\text { bis(2-Chloroisopropyl) ether } \\
\text { bis(2-Chloroethoxy) methane } \\
\text { Hexachlorobutadiene } \\
\text { Hexachlorocyclopentadiene } \\
\text { 4-Bromophenyl phenyl ether } \\
\text { 4-Chlorophenyl phenyl ether } \\
\text { 2-Chloronaphthalene }\end{array}$ & $\begin{array}{l}\text { WWR } \\
\text { WWR } \\
\text { WWR } \\
\text { WWR } \\
\text { WWR } \\
\text { WWR } \\
\text { WWR } \\
\text { WWR } \\
\text { WWR }\end{array}$ & $\begin{array}{l}{ }^{b} \mathrm{O}-3116-87 \\
{ }^{b} O-3116-87 \\
{ }^{b} O-3116-87 \\
{ }^{b} O-3116-87 \\
{ }^{b} O-3116-87 \\
{ }^{b} O-3116-87 \\
{ }^{b} O-3116-87 \\
{ }^{b} O-3116-87 \\
{ }^{b} O-3116-87\end{array}$ & $\begin{array}{l}\text { GC/MS } \\
\text { GC/MS } \\
\text { GC/MS } \\
\text { GC/MS } \\
\text { GC/MS } \\
\text { GC/MS } \\
\text { GC/MS } \\
\text { GC/MS } \\
\text { GC/MS }\end{array}$ & $\begin{array}{l}5 \mu \mathrm{g} / \mathrm{L} \\
5 \mu \mathrm{g} / \mathrm{L} \\
5 \mu \mathrm{g} / \mathrm{L} \\
5 \mu \mathrm{g} / \mathrm{L} \\
5 \mu \mathrm{g} / \mathrm{L} \\
5 \mu \mathrm{g} / \mathrm{L} \\
5 \mu \mathrm{g} / \mathrm{L} \\
5 \mu \mathrm{g} / \mathrm{L} \\
5 \mu \mathrm{g} / \mathrm{L}\end{array}$ & $\begin{array}{l}4^{\circ} \mathrm{C} \\
4^{\circ} \mathrm{C} \\
4^{\circ} \mathrm{C} \\
4^{\circ} \mathrm{C} \\
4^{\circ} \mathrm{C} \\
4^{\circ} \mathrm{C} \\
4^{\circ} \mathrm{C} \\
4^{\circ} \mathrm{C} \\
4^{\circ} \mathrm{C}\end{array}$ & $\begin{array}{l}\text { GB1000 } \\
\text { GB1000 } \\
\text { GB1000 } \\
\text { GB1000 } \\
\text { GB1000 } \\
\text { GB1000 } \\
\text { GB1000 } \\
\text { GB1000 } \\
\text { GB1000 }\end{array}$ \\
\hline \multicolumn{7}{|c|}{ Substituted Biphenyl } \\
\hline $\begin{array}{l}\text { 4,4'-Diaminobiphenyl } \\
\text { 4,4'-Diamino-3,3'- } \\
\text { dichlorobiphenyl }\end{array}$ & $\begin{array}{l}\text { WWR } \\
\text { WWR }\end{array}$ & $\begin{array}{l}{ }^{b} \mathrm{O}-3116-87 \\
{ }^{\mathrm{b}} \mathrm{O}-3116-87\end{array}$ & $\begin{array}{l}\text { GC/MS } \\
\text { GC/MS }\end{array}$ & $\begin{array}{l}40 \mu \mathrm{g} / \mathrm{L} \\
20 \mu \mathrm{g} / \mathrm{L}\end{array}$ & $\begin{array}{l}4^{\circ} \mathrm{C} \\
4^{\circ} \mathrm{C}\end{array}$ & $\begin{array}{l}\text { GB1000 } \\
\text { GB1000 }\end{array}$ \\
\hline
\end{tabular}

a Fishman and Friedman (1989).

${ }^{b}$ Methods of analysis from Fishman (1993).

${ }^{c}$ Patton and Truitt (1992).

¿ U.S. Environmental Protection Agency (1983).

e Wershaw and others (1983).

${ }^{f}$ Analyzed for discrete samples.

${ }^{g}$ U.S. Environmental Agency (1991).

${ }^{\text {h }}$ U.S. Environmental Agency (1988).

${ }^{\mathrm{i}}$ Methylene chloride extractable organic compounds.

Table 3. Methods, detection limits, preservations, and bottle types used for determination of constituent concentrations at the Enseco Rocky Mountain Analytical Laboratory, Arvada, Colorado

[ $\mu \mathrm{g} / \mathrm{L}$, micrograms per liter, $\mathrm{HNO}_{3}$, nitric acid; PA250, 250-milliliter polyethylene, acid rinsed; mg/L, milligrams per liter; $\mathrm{NaOH}$, sodium hydroxide; ${ }^{\circ} \mathrm{C}$, degrees Celsius; $\mathrm{P} 250,250$-milliliter polyethylene]

\begin{tabular}{|c|c|c|c|c|c|c|}
\hline Constltuent & Phase & Sample type & $\begin{array}{c}\text { U.S. Environmental } \\
\text { Protectlon Agency } \\
\text { analytical } \\
\text { method number }\end{array}$ & $\begin{array}{c}\text { Detection } \\
\text { limlt }\end{array}$ & Perservation & Bottle type \\
\hline Antimony & Total & Composite & 204.2 & $10 \mu \mathrm{g} / \mathrm{L}$ & $\mathrm{HNO}_{3}$ & PA250 \\
\hline Silver & Total & Composite & 272.2 & $.5 \mu \mathrm{g} / \mathrm{L}$ & $\mathrm{HNO}_{3}$ & PA250 \\
\hline Thallium & Total & Composite & 279.2 & $5.0 \mu \mathrm{g} / \mathrm{L}$ & $\mathrm{HNO}_{3}$ & PA250 \\
\hline Cyanide & Total & First flush & 335.3 & $.01 \mathrm{mg} / \mathrm{L}$ & $\mathrm{NaOH}, 4^{\circ} \mathrm{C}$ & P250 \\
\hline
\end{tabular}

a U.S. Environmental Protection Agency, 1983. 

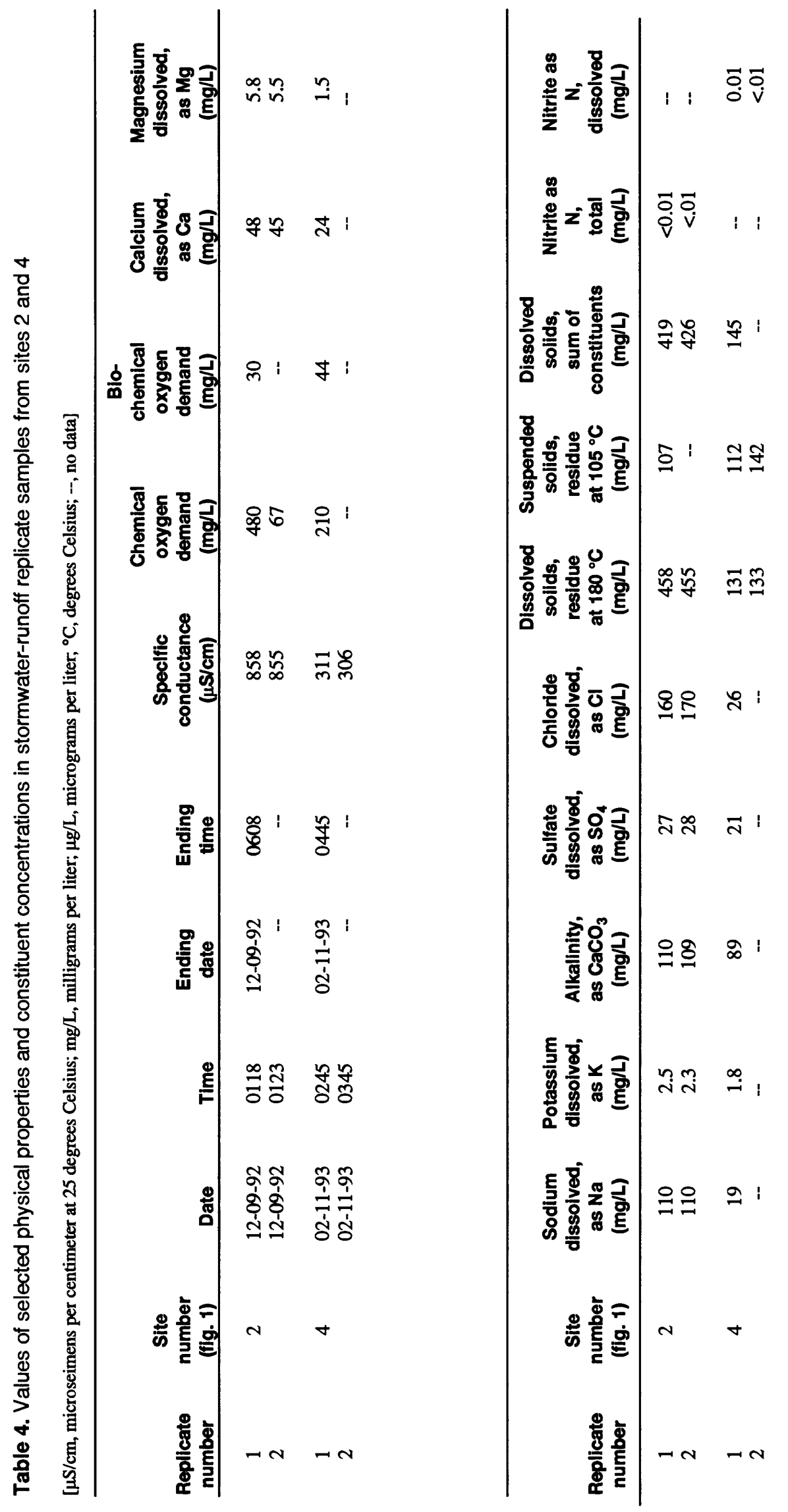


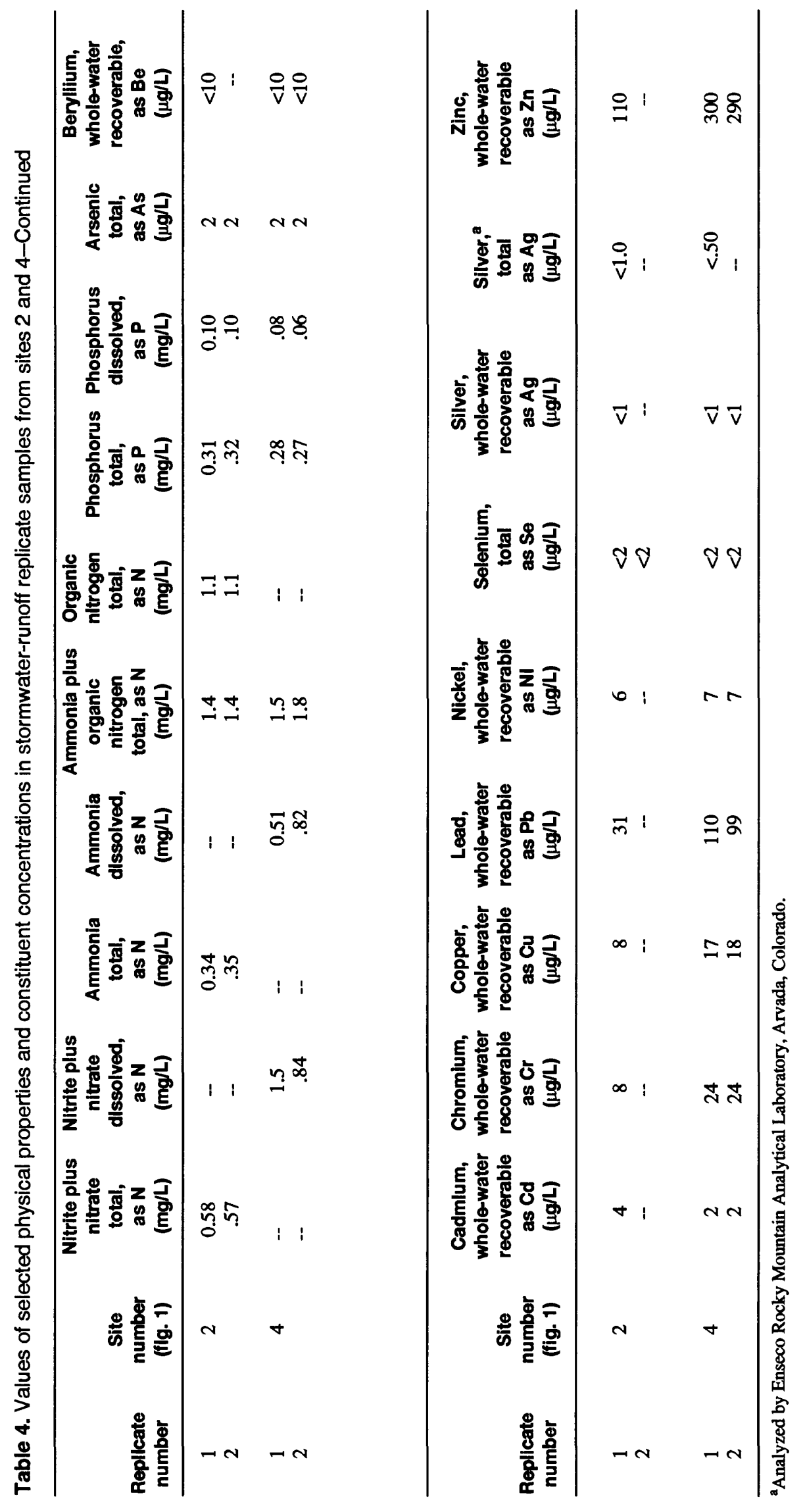




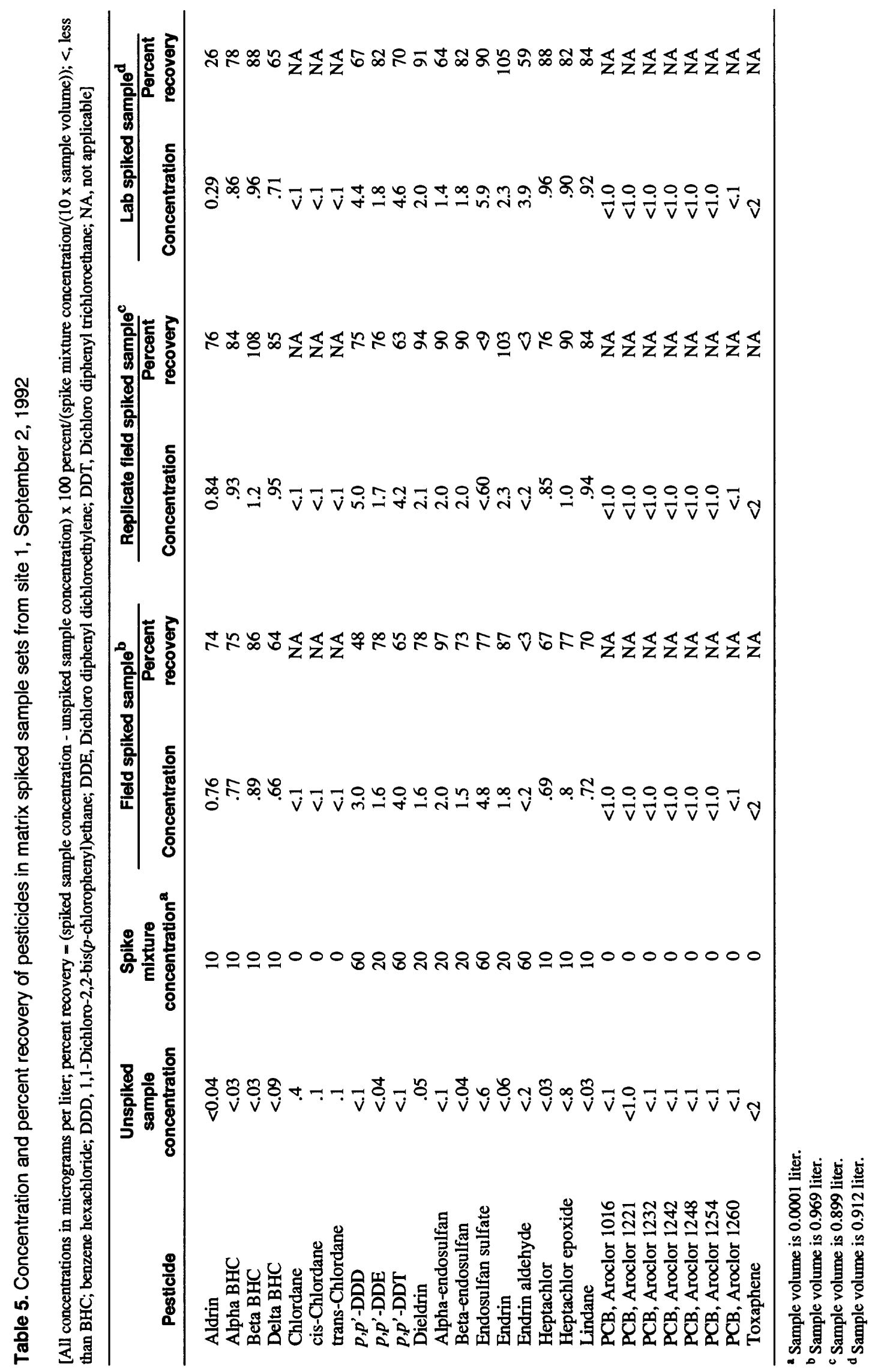




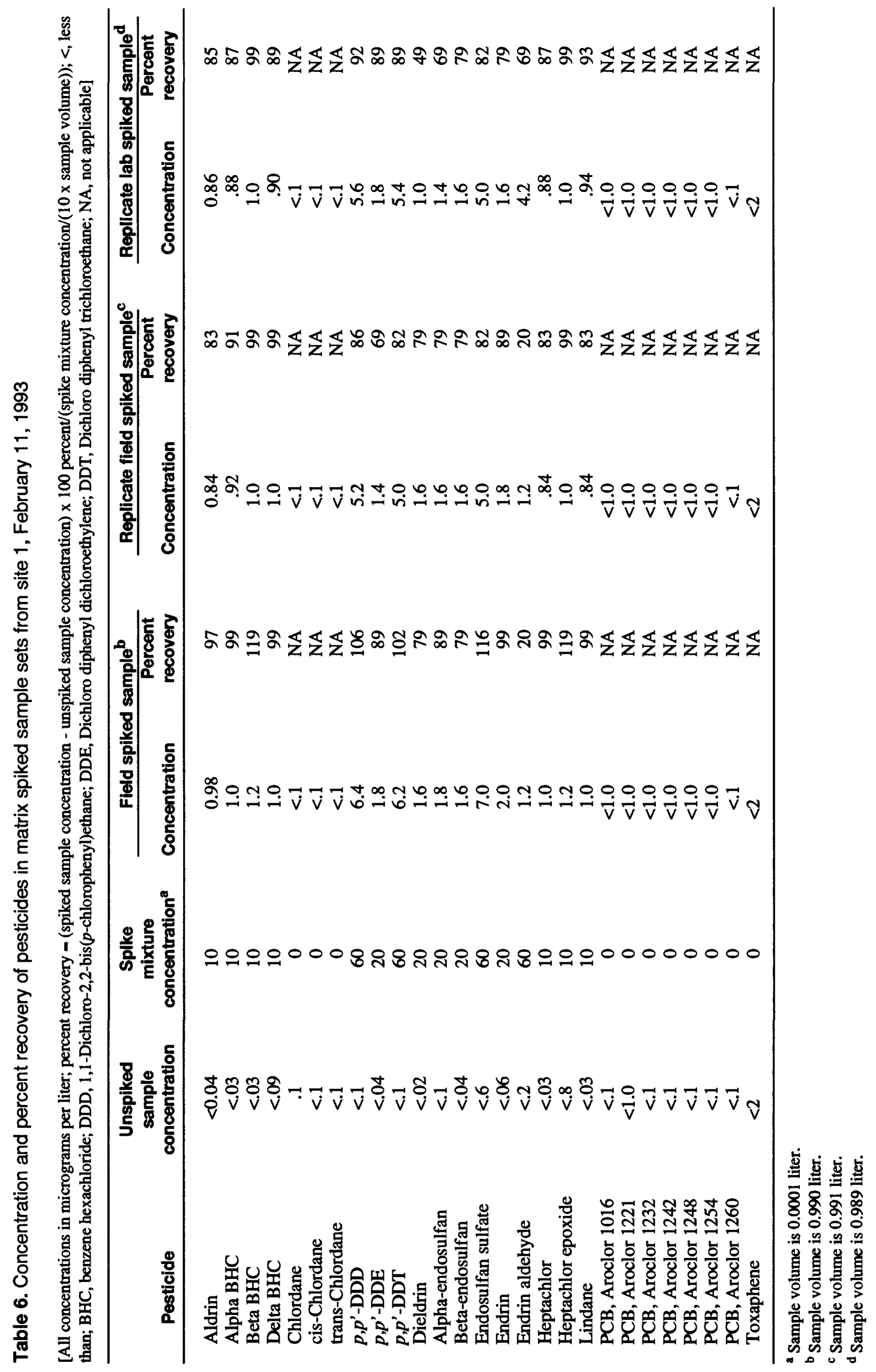




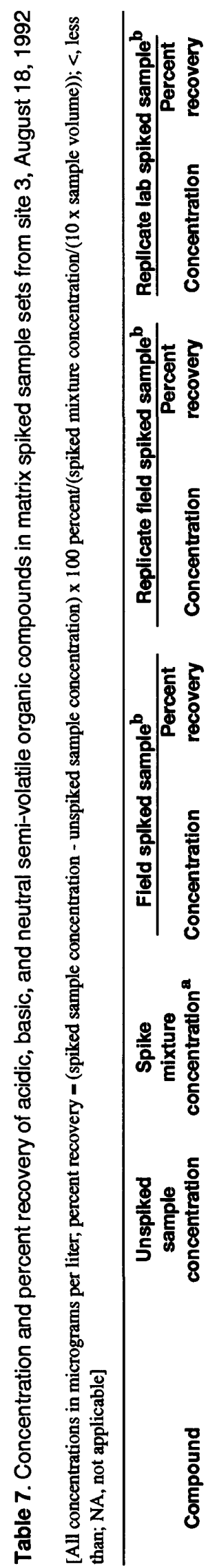

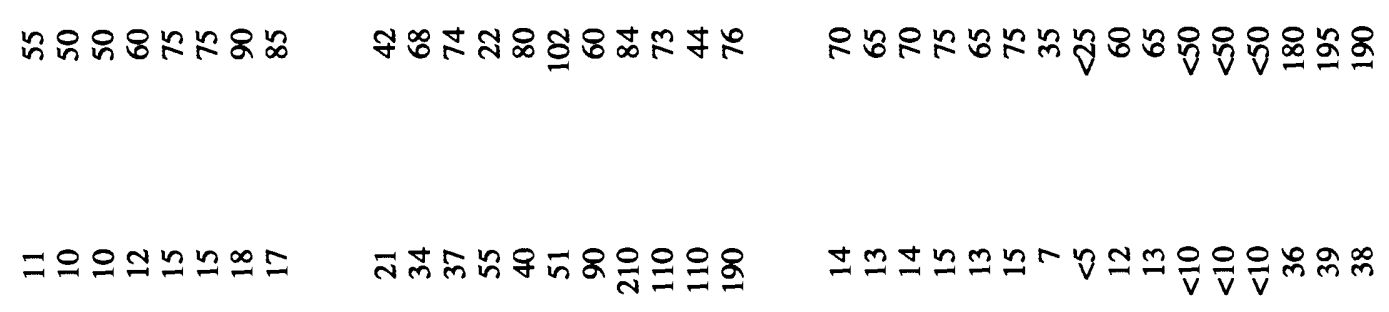

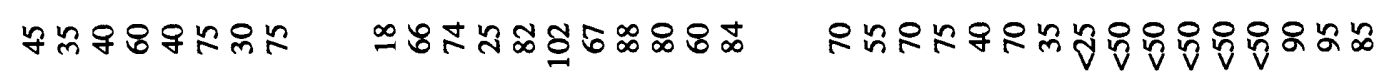

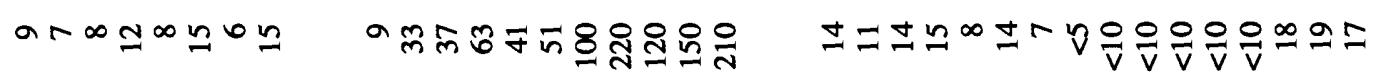

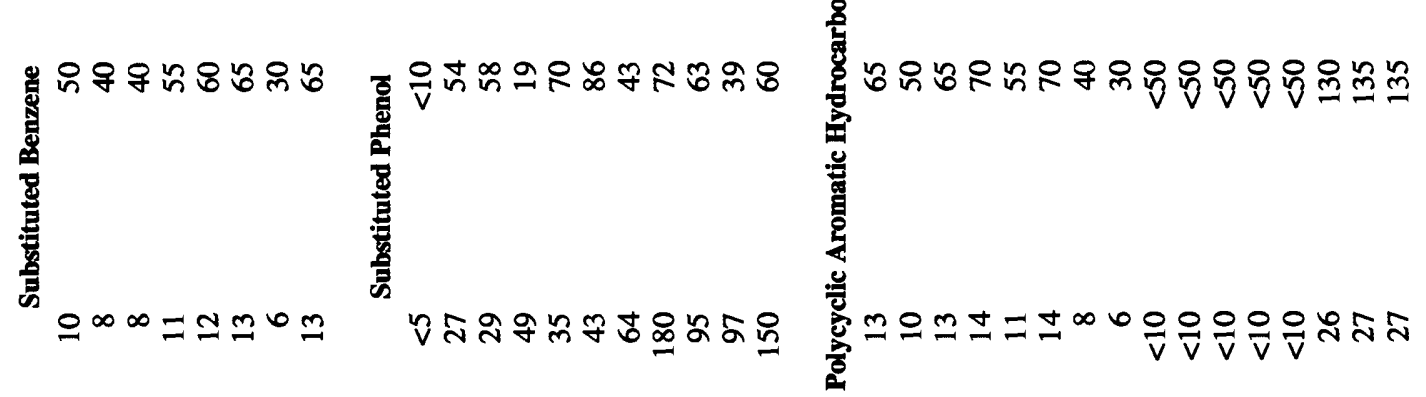

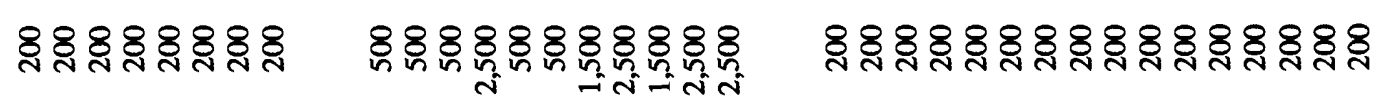

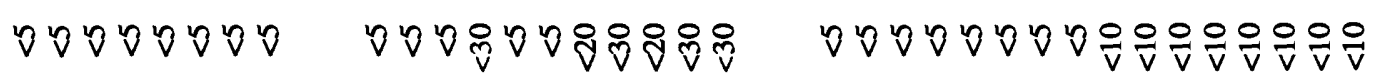
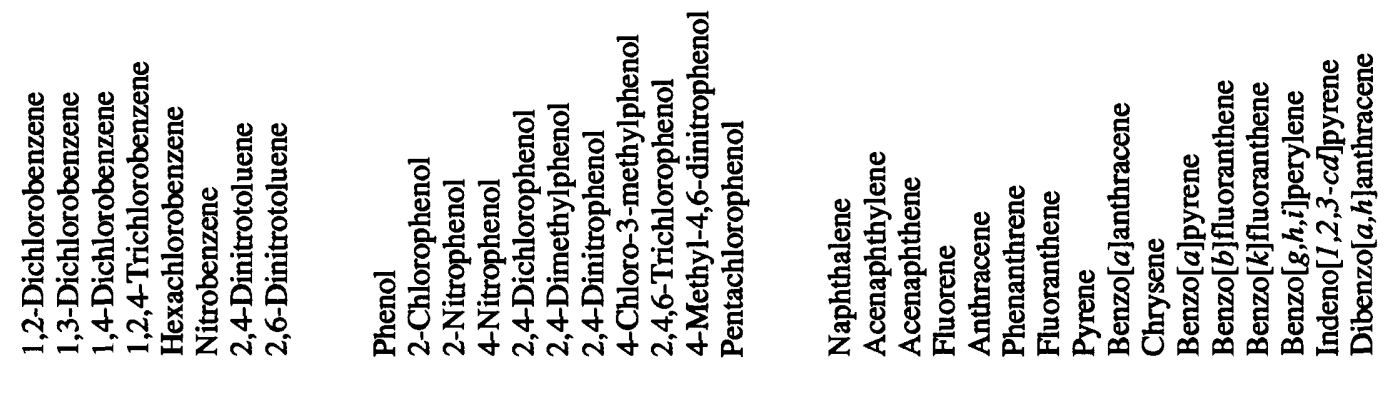


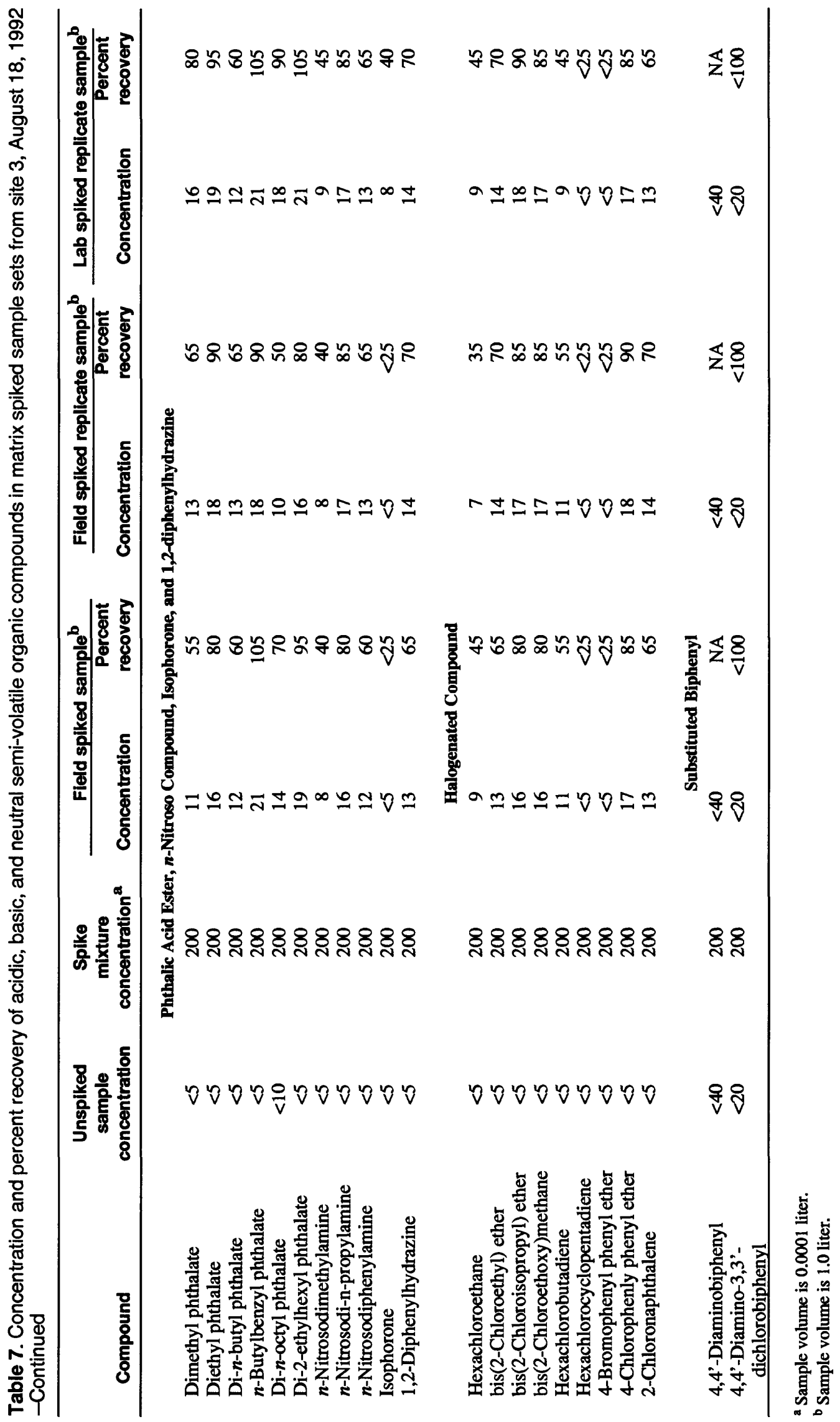


Table 8. Concentration and percent recovery of volatile organic compounds in matrix spiked sample sets from site 2 , December 9, 1992

[All concentrations in micrograms per liter; percent recovery = (Lab spiked sample concentration - unspiked sample concentration) $\times 100$ percent/ (spiked mixture concentration/(10 x sample volume)); <, less than; sample volume is $\mathbf{4 0}$ milliliters]

\begin{tabular}{|c|c|c|c|c|}
\hline \multirow[b]{2}{*}{ Compound } & \multirow{2}{*}{$\begin{array}{c}\text { Unspiked } \\
\text { sample } \\
\text { concentration }\end{array}$} & \multirow{2}{*}{$\begin{array}{c}\text { Spiked } \\
\text { mixture } \\
\text { concentration }\end{array}$} & \multicolumn{2}{|c|}{ Lab spiked sample } \\
\hline & & & Concentration & $\begin{array}{l}\text { Percent } \\
\text { recovery }\end{array}$ \\
\hline Bromomethane & $<0.2$ & 4.8 & 6.8 & 57 \\
\hline Bromoform & $<.2$ & 5.8 & 13 & 90 \\
\hline Dibromochloromethane & $<.2$ & 6.1 & 13 & 85 \\
\hline Chloromethane & $<.2$ & 3.5 & 10 & 114 \\
\hline Dichloromethane & $<.2$ & 7.9 & 16 & 81 \\
\hline Trichloromethane & $<.2$ & 5.2 & 10 & 77 \\
\hline Tetrachloromethane & $<.2$ & 5.4 & 12 & 89 \\
\hline Dichlorobromomethane & $<.2$ & 5.7 & 12 & 84 \\
\hline Trichlorofluoromethane & $<2$ & 2.6 & 5.7 & 88 \\
\hline Chloroethane & $<.2$ & 4.1 & 9.5 & 93 \\
\hline 1,1-Dichloroethane & $<.2$ & 4.9 & 10 & 82 \\
\hline 1,2-Dichloroethane & $<.2$ & 5.0 & 11 & 88 \\
\hline 1,1,1-Trichloroethane & $<.2$ & 4.4 & 11 & 100 \\
\hline 1,1,2-Trichloroethane & $<.2$ & 5.4 & 12 & 89 \\
\hline $1,1,2,2$-Tetrachloroethane & $<.2$ & 5.0 & 12 & 96 \\
\hline Chloroethene & $<.2$ & 3.5 & 7.9 & 90 \\
\hline 1,1-Dichloroethene & $<.2$ & 4.3 & 8.6 & 80 \\
\hline cis-1,2-Dichloroethene & $<.2$ & 5.1 & 10 & 78 \\
\hline trans-1,2-Dichloroethene & $<.2$ & 5.0 & 9.1 & 73 \\
\hline 1,1,2-Trichloroethene & $<.2$ & 5.3 & 11 & 83 \\
\hline 1,1,2,2-Tetrachloroethene & $<.2$ & 5.6 & 12 & 86 \\
\hline 1,2-Dichloropropane & $<.2$ & 5.1 & 11 & 86 \\
\hline cis-1,3-Dichloropropene & $<.2$ & 4.8 & 10 & 83 \\
\hline trans-1,3-Dichloropropene & $<.2$ & 6.1 & 14 & 92 \\
\hline Benzene & $<.2$ & 5.1 & 11 & 86 \\
\hline Chlorobenzene & $<.2$ & 5.9 & 12 & 81 \\
\hline Ethylbenzene & $<.2$ & 6.1 & 12 & 79 \\
\hline Toluene & $<.2$ & 6.1 & 13 & 85 \\
\hline
\end{tabular}


Table 9. Statistical summary of physical properties and constituent concentrations in water samples collected at baseflow sampling sites in October 1991 and January to February 1992

$\left[\mathrm{ft}^{3} / \mathrm{s}\right.$, cubic feet per second; $\mu \mathrm{S} / \mathrm{cm}$, microsiemens per centimeter at 25 degrees Celsius; ${ }^{\circ} \mathrm{C}$, degrees Celsius; mg/L, milligram per liter; <, less than; $\mu \mathrm{g} / \mathrm{L}$, microgram per liter; NA, not applicable; $\mathrm{pH}$, in standard units]

\begin{tabular}{|c|c|c|c|c|c|c|}
\hline $\begin{array}{c}\text { Constituent } \\
\text { or } \\
\text { physical property }\end{array}$ & $\begin{array}{c}\text { Detectlon } \\
\text { limlt }\end{array}$ & $\begin{array}{l}\text { Number of } \\
\text { occurrences } \\
\text { greater than } \\
\text { detectlon limit }^{\mathbf{a}}\end{array}$ & $\begin{array}{l}\text { Number of } \\
\text { sites with } \\
\text { occurrences } \\
\text { greater than } \\
\text { detection limitb }\end{array}$ & $\begin{array}{l}\text { Mean of } \\
\text { occurrences } \\
\text { greater than } \\
\text { detection limit }\end{array}$ & Minimum & Maximum \\
\hline Discharge & $0.001 \mathrm{ft}^{3} / \mathrm{s}$ & $c_{219}$ & 187 & 0.126 & $<0.001$ & 10.1 \\
\hline Specific conductance & $.5 \mu \mathrm{S} / \mathrm{cm}$ & $d_{225}$ & 192 & 899 & 325 & 2,530 \\
\hline $\mathrm{pH}$ & 4.0 to 10.0 & $e_{222}$ & 189 & $f_{7.9}$ & 6.7 & 9.8 \\
\hline Temperature & $50^{\circ} \mathrm{C}$ & $e_{222}$ & 189 & 9.3 & .5 & 24.0 \\
\hline Chlorine, total & $.1 \mathrm{mg} / \mathrm{L}$ & $\mathrm{g}_{45}$ & 39 & .23 & $<.1$ & .90 \\
\hline Copper, total & $.1 \mu \mathrm{g} / \mathrm{L}$ & 0 & 0 & NA & $<.1$ & $<.1$ \\
\hline Detergents, total & $.05 \mathrm{mg} / \mathrm{L}$ & 1 & 1 & .3 & $<.05$ & .3 \\
\hline Phenols, total & $.02 \mathrm{mg} / \mathrm{L}$ & 0 & 0 & NA & $<.02$ & $<.02$ \\
\hline
\end{tabular}

a Two-hundred twenty-six total samples.

${ }^{b}$ One hundred ninety-three total sites.

${ }^{c}$ Discharge was not measured for one sample.

d One sample not analyzed.

e Four samples not analyzed.

${ }^{f}$ If $\mathrm{pH}$ is not normally distributed, mean $\mathrm{pH}$ will not satisfactorily summarize the typical hydrogen ion concentration.

g Three samples not analyzed. 
Table 10. Values of selected physical properties and constituent concentrations of water samples collected during baseflow conditions

[A, Adair Creek; B, Bundschu Creek; BR, Blue River; C, Crackerneck Creek; FP, Fire Prairie Creek; LB, Little Blue River; M, Mill Creek; R, Rock Creek; S, Sugar Creek; SB, Spring Branch Creek; WFP, West Fire Prairie Creek; $\mathrm{ft}^{3} / \mathrm{s}$, cubic feet per second; ${ }^{\circ} \mathrm{C}$, degrees Celsius; mg/L, milligrams per liter; $\mu \mathrm{S} / \mathrm{cm}$, microseimens per centimeter at 25 degrees Celsius; <, less than; --, no data]

\begin{tabular}{|c|c|c|c|c|c|c|c|c|c|c|}
\hline $\begin{array}{c}\text { Slte } \\
\text { number } \\
\text { (filg. 2) }\end{array}$ & Date & TIme & $\begin{array}{c}\text { Discharge } \\
\left(\mathrm{ft}^{3} / \mathrm{s}\right)\end{array}$ & $\begin{array}{c}\text { Specific } \\
\text { conductance } \\
(\mu S / \mathrm{cm})\end{array}$ & $\underset{\text { (units) }}{\mathrm{pH}}$ & $\begin{array}{c}\text { Temperature } \\
\left({ }^{\circ} \mathrm{C}\right)\end{array}$ & $\begin{array}{c}\text { Total } \\
\text { chiorine } \\
\text { (mg/L) }\end{array}$ & $\begin{array}{c}\text { Total } \\
\text { copper } \\
\text { (mg/L) }\end{array}$ & $\begin{array}{c}\text { Total } \\
\text { detergents } \\
\text { (mg/L) }\end{array}$ & $\begin{array}{c}\text { Total } \\
\text { phenols }^{\text {a }} \\
\text { (mgll) }\end{array}$ \\
\hline A1 & $01-29-92$ & 1105 & 0.79 & 802 & 8.0 & 2.0 & $<0.10$ & $<0.1$ & $<0.05$ & $<0.02$ \\
\hline A2 & $01-29-92$ & 1330 & .73 & 772 & 8.1 & 2.0 & $<.10$ & $<.1$ & $<.05$ & $<.02$ \\
\hline $\mathrm{A} 3$ & $01-29-92$ & 1425 & .007 & 971 & 8.0 & 10.0 & $<.10$ & $<.1$ & $<.05$ & $<.02$ \\
\hline A4 & $01-29-92$ & 1430 & .48 & 795 & -- & -- & .10 & $<.1$ & $<.05$ & $<.02$ \\
\hline \multirow[t]{2}{*}{ A5 } & $01-30-92$ & 0800 & .002 & 1,240 & 7.6 & 10.5 & $<.10$ & $<.1$ & $<.05$ & $<.02$ \\
\hline & $01-31-92$ & 0800 & .02 & 1,250 & 7.7 & 8.5 & $<.10$ & $<.1$ & $<.05$ & $<.02$ \\
\hline A6 & $01-30-92$ & 0835 & .005 & 849 & 7.8 & 6.5 & $<.10$ & $<.1$ & $<.05$ & $<.02$ \\
\hline A7 & $01-30-92$ & 0845 & .01 & 658 & 8.1 & 6.5 & $<.10$ & $<.1$ & $<.05$ & $<.02$ \\
\hline A8 & $01-30-92$ & 1030 & .82 & 810 & 8.1 & 2.5 & $<.10$ & $<.1$ & $<.05$ & $<.02$ \\
\hline \multirow[t]{2}{*}{ A9 } & $01-30-92$ & 1230 & .17 & 1,160 & 7.8 & 9.5 & $<.10$ & $<.1$ & $<.05$ & $<.02$ \\
\hline & $01-31-92$ & 0855 & .007 & 1,140 & 8.0 & 7.5 & $<.10$ & $<.1$ & $<.05$ & $<.02$ \\
\hline \multirow[t]{2}{*}{ A10 } & $01-30-92$ & 1300 & $<.001$ & 775 & 8.4 & 9.0 & .15 & $<.1$ & $<.05$ & $<.02$ \\
\hline & $01-31-92$ & 0845 & $<.001$ & 772 & 8.2 & 5.5 & $<.10$ & $<.1$ & $<.05$ & $<.02$ \\
\hline \multirow[t]{2}{*}{ A11 } & $01-30-92$ & 1320 & .005 & 953 & 8.0 & 3.0 & $<.10$ & $<.1$ & $<.05$ & $<.02$ \\
\hline & $01-31-92$ & 0835 & .006 & 960 & 8.2 & 2.5 & $<.10$ & $<.1$ & $<.05$ & $<.02$ \\
\hline \multirow[t]{2}{*}{ A12 } & $01-30-92$ & 1330 & .005 & 1,240 & 8.2 & 10.5 & $<.10$ & $<.1$ & $<.05$ & $<.02$ \\
\hline & $01-31-92$ & 0825 & .003 & 1,230 & 8.3 & 4.5 & $<.10$ & $<.1$ & $<.05$ & $<.02$ \\
\hline A13 & $01-30-92$ & 1350 & .44 & 839 & 8.4 & 8.0 & $<.10$ & $<.1$ & $<.05$ & $<.02$ \\
\hline \multirow[t]{2}{*}{ A14 } & $01-30-92$ & 1425 & .04 & 1,000 & 7.8 & 9.0 & $<.10$ & $<.1$ & $<.05$ & $<.02$ \\
\hline & $01-31-92$ & 0905 & .03 & 1,000 & 8.2 & 8.5 & $<.10$ & $<.1$ & $<.05$ & $<.02$ \\
\hline A15 & $01-30-92$ & 1430 & .27 & 831 & 8.4 & 8.5 & $<.10$ & $<.1$ & $<.05$ & $<.02$ \\
\hline A16 & $01-30-92$ & 1500 & .10 & 918 & 8.1 & 8.0 & $<.10$ & $<.1$ & $<.05$ & $<.02$ \\
\hline \multirow[t]{2}{*}{ A17 } & $01-30-92$ & 1515 & .09 & 875 & 8.0 & 5.5 & $<.10$ & $<.1$ & $<.05$ & $<.02$ \\
\hline & $01-31-92$ & 0915 & .08 & 910 & 8.5 & 4.5 & $<.10$ & $<.1$ & $<.05$ & $<.02$ \\
\hline A18 & $01-31-92$ & 0945 & .05 & 902 & 8.3 & 3.5 & $<.10$ & $<.1$ & $<.05$ & $<.02$ \\
\hline A19 & $01-31-92$ & 1030 & .06 & 1,030 & 8.3 & 8.5 & $<.10$ & $<.1$ & $<.05$ & $<.02$ \\
\hline A50 & $01-30-92$ & 1000 & .04 & 773 & 8.0 & 4.0 & $<.10$ & $<.1$ & $<.05$ & $<.02$ \\
\hline \multirow[t]{2}{*}{ A51 } & $01-30-92$ & 1040 & .02 & 584 & 7.8 & 4.5 & $<.10$ & $<.1$ & $<.05$ & $<.02$ \\
\hline & $01-31-92$ & 0800 & .01 & 745 & 7.6 & 10.0 & .15 & $<.1$ & $<.05$ & $<.02$ \\
\hline A52 & $01-30-92$ & 1130 & .04 & 972 & 7.8 & 5.0 & $<.10$ & $<.1$ & $<.05$ & $<.02$ \\
\hline A53 & $01-30-92$ & 1245 & .03 & 978 & 8.1 & 5.0 & .10 & $<.1$ & $<.05$ & $<.02$ \\
\hline A54 & $01-30-92$ & 1300 & .003 & 982 & 7.9 & 5.5 & $<.10$ & $<.1$ & $<.05$ & $<.02$ \\
\hline A55 & $01-30-92$ & 1315 & .10 & 768 & 8.3 & 6.0 & $<.10$ & $<.1$ & $<.05$ & $<.02$ \\
\hline A56 & $01-30-92$ & 1350 & .01 & 753 & 7.0 & 18.0 & .30 & $<.1$ & $<.05$ & $<.02$ \\
\hline A57 & $01-30-92$ & 1415 & .004 & 754 & 7.0 & 10.0 & $<.10$ & $<.1$ & $<.05$ & $<.02$ \\
\hline A58 & $01-30-92$ & 1435 & .08 & 769 & 8.5 & 6.5 & $<.10$ & $<.1$ & $<.05$ & $<.02$ \\
\hline A59 & $01-30-92$ & 1500 & .02 & 778 & 7.9 & 9.0 & $<.10$ & $<.1$ & $<.05$ & $<.02$ \\
\hline A60 & $01-30-92$ & 1530 & .009 & 848 & 8.1 & 8.5 & $<.10$ & $<.1$ & $<.05$ & $<.02$ \\
\hline A95 & $01-31-92$ & 1240 & .06 & 916 & 8.5 & 13.5 & $<.10$ & $<.1$ & $<.05$ & $<.02$ \\
\hline A96 & $01-31-92$ & 1210 & .003 & 1,020 & 8.2 & 11.5 & .15 & $<.1$ & $<.05$ & $<.02$ \\
\hline A97 & $01-31-92$ & 1150 & .10 & 960 & 8.2 & 6.0 & $<.10$ & $<.1$ & $<.05$ & $<.02$ \\
\hline \multirow[t]{3}{*}{ A98 } & $01-31-92$ & 1120 & .031 & 1,000 & 8.0 & 10.0 & $<.10$ & $<.1$ & $<.05$ & $<.02$ \\
\hline & $02-03-92$ & 0840 & .04 & 958 & 8.2 & 11.0 & $<.10$ & $<.1$ & $<.05$ & $<.02$ \\
\hline & $02-03-92$ & 1300 & .04 & 907 & 8.1 & 11.5 & $<.10$ & $<.1$ & $<.05$ & $<.02$ \\
\hline \multirow{3}{*}{ A99 } & $01-31-92$ & 1110 & .02 & 891 & 7.5 & 7.0 & $<.10$ & $<.1$ & $<.05$ & $<.02$ \\
\hline & $02-03-92$ & 0900 & .03 & 664 & 8.0 & 8.0 & .10 & $<.1$ & $<.05$ & $<.02$ \\
\hline & $02-03-92$ & 1315 & .03 & 653 & 8.5 & 10.0 & $<.10$ & $<.1$ & $<.05$ & $<.02$ \\
\hline
\end{tabular}


Table 10. Values of selected physical properties and constituent concentrations of water samples collected during baseflow conditions-Continued

\begin{tabular}{|c|c|c|c|c|c|c|c|c|c|c|}
\hline $\begin{array}{c}\text { SIte } \\
\text { number } \\
\text { (filg. 2) }\end{array}$ & Date & TIme & $\begin{array}{c}\begin{array}{c}\text { Dlscharge } \\
\left(\mathrm{t}^{3} / \mathrm{s}\right)\end{array} \\
\end{array}$ & $\begin{array}{c}\text { Specific } \\
\text { conductance } \\
(\mu \mathrm{S} / \mathrm{cm})\end{array}$ & $\begin{array}{c}\mathrm{pH} \\
\text { (units) }\end{array}$ & $\begin{array}{c}\text { Temperature } \\
\left({ }^{\circ} \mathrm{C}\right)\end{array}$ & $\begin{array}{c}\text { Total } \\
\text { chlorine } \\
\text { (mg/L) } \\
\end{array}$ & $\begin{array}{c}\text { Total } \\
\text { coppera } \\
\text { (mg/L) }\end{array}$ & $\begin{array}{c}\text { Total } \\
\text { detergents } \\
\text { (mg/L) }\end{array}$ & $\begin{array}{c}\text { Total } \\
\text { phenols } \\
\text { (mg/L) }\end{array}$ \\
\hline A100 & $01-31-92$ & 0855 & 0.03 & 670 & 7.5 & 7.5 & $<0.10$ & $<0.1$ & $<0.05$ & $<0.02$ \\
\hline A101 & $01-31-92$ & 0910 & .005 & 1,440 & 7.9 & 4.0 & $<.10$ & $<.1$ & $<.05$ & $<.02$ \\
\hline $\mathrm{A} 102$ & $01-31-92$ & 0925 & .003 & 1,120 & 8.1 & 6.0 & $<.10$ & $<.1$ & $<.05$ & $<.02$ \\
\hline A103 & $01-31-92$ & 0950 & .02 & 1,020 & 7.8 & 5.0 & $<.10$ & $<.1$ & $<.05$ & $<.02$ \\
\hline \multirow[t]{3}{*}{ A104 } & $01-31-92$ & 1015 & .02 & 966 & 8.3 & 5.5 & $<.10$ & $<.1$ & $<.05$ & $<.02$ \\
\hline & $02-03-92$ & 0930 & .02 & 931 & 8.2 & 7.0 & $<.10$ & $<.1$ & $<.05$ & $<.02$ \\
\hline & $02-03-92$ & 1330 & .02 & 911 & 8.2 & 7.0 & .20 & $<.1$ & $<.05$ & $<.02$ \\
\hline \multirow{2}{*}{ A110 } & $02-03-92$ & 0915 & .004 & 1,390 & 8.2 & 7.0 & $<.10$ & $<.1$ & $<.05$ & $<.02$ \\
\hline & $02-03-92$ & 1315 & .004 & 1,350 & 8.3 & 8.0 & $<.10$ & $<.1$ & $<.05$ & $<.02$ \\
\hline B1 & $10-17-91$ & 0800 & .18 & 696 & 7.8 & 12.0 & $<.10$ & $<.1$ & $<.05$ & $<.02$ \\
\hline $\mathrm{B} 2$ & $10-17-91$ & 0850 & .10 & 778 & 8.0 & 11.5 & $<.10$ & $<.1$ & $<.05$ & $<.02$ \\
\hline B3 & $10-17-91$ & 0930 & .24 & 685 & 7.9 & 11.5 & $<.10$ & $<.1$ & $<.05$ & $<.02$ \\
\hline B4 & $10-17-91$ & 1005 & .16 & 828 & 7.6 & 13.0 & .30 & $<.1$ & $<.05$ & $<.02$ \\
\hline B5 & $10-17-91$ & 1025 & .03 & 867 & 7.9 & 12.5 & $<.10$ & $<.1$ & $<.05$ & $<.02$ \\
\hline B6 & $10-17-91$ & 1040 & .006 & 894 & 7.8 & 13.5 & $<.10$ & $<.1$ & $<.05$ & $<.02$ \\
\hline B7 & $10-17-91$ & 1110 & .02 & 637 & 8.3 & 14.5 & $<.10$ & $<.1$ & $<.05$ & $<.02$ \\
\hline B8 & $10-17-91$ & 1125 & .03 & 878 & 7.9 & 17.0 & $<.10$ & $<.1$ & $<.05$ & $<.02$ \\
\hline B9 & $10-17-91$ & 1140 & .01 & 840 & 8.1 & 17.0 & $<.10$ & $<.1$ & $<.05$ & $<.02$ \\
\hline B10 & $10-17-91$ & 1200 & .02 & 680 & 7.6 & 16.0 & $<.10$ & $<.1$ & $<.05$ & $<.02$ \\
\hline B11 & $10-17-91$ & 1300 & .02 & 1,010 & 7.4 & 17.5 & .20 & $<.1$ & $<.05$ & $<.02$ \\
\hline \multirow[t]{2}{*}{ B12 } & $10-17-91$ & 1330 & .04 & 892 & 7.3 & 17.5 & $<.10$ & $<.1$ & $<.05$ & $<.02$ \\
\hline & $10-18-91$ & 0800 & -- & 895 & -- & -- & -- & $<.1$ & $<.05$ & $<.02$ \\
\hline BR1 & $02-03-92$ & 1445 & .01 & 1,200 & 8.1 & 8.5 & $<.10$ & $<.1$ & $<.05$ & $<.02$ \\
\hline $\mathrm{C} 1$ & $10-21-91$ & 0840 & .08 & 898 & 7.9 & 7.5 & $<.10$ & $<.1$ & $<.05$ & $<.02$ \\
\hline $\mathrm{C} 2$ & $10-21-91$ & 0920 & .11 & 836 & 7.7 & 8.0 & $<.10$ & $<.1$ & $<.05$ & $<.02$ \\
\hline $\mathrm{C} 3$ & $10-21-91$ & 1020 & .12 & 920 & 7.7 & 9.0 & $<.10$ & $<.1$ & $<.05$ & $<.02$ \\
\hline $\mathrm{C} 4$ & $10-21-91$ & 1055 & $<.001$ & 738 & -- & -- & $<.10$ & $<.1$ & $<.05$ & $<.02$ \\
\hline $\mathrm{C} 5$ & $10-21-91$ & -. & .04 & 1,140 & 7.7 & 13.0 & $<.10$ & $<.1$ & $<.05$ & $<.02$ \\
\hline \multirow{2}{*}{ C6 } & $10-21-91$ & 1325 & .01 & 1,300 & 7.6 & 17.0 & $<.10$ & $<.1$ & $<.05$ & $<.02$ \\
\hline & $10-22-91$ & 0800 & .01 & 2,480 & -- & -- & -- & $<.1$ & $<.05$ & $<.02$ \\
\hline C7 & $10-22-91$ & 0912 & .05 & 1,040 & 7.6 & 13.0 & .10 & $<.1$ & $<.05$ & $<.02$ \\
\hline $\mathrm{C} 8$ & $10-22-91$ & 0950 & .05 & 886 & 7.9 & 12.0 & $<.10$ & $<.1$ & $<.05$ & $<.02$ \\
\hline \multirow[t]{2}{*}{ C9 } & $10-22-91$ & 1050 & .05 & 822 & 7.9 & 16.0 & $<.10$ & $<.1$ & $<.05$ & $<.02$ \\
\hline & $10-23-91$ & 1345 & .04 & 720 & 7.4 & 22.5 & $<.10$ & $<.1$ & $<.05$ & $<.02$ \\
\hline $\mathrm{C} 10$ & $10-22-91$ & 1225 & .04 & 730 & 7.4 & 14.0 & .20 & $<.1$ & $<.05$ & $<.02$ \\
\hline $\mathrm{C} 11$ & $10-22-91$ & 1325 & .04 & 560 & 7.8 & 11.0 & .30 & $<.1$ & $<.05$ & $<.02$ \\
\hline $\mathrm{C} 20$ & $10-23-91$ & 0945 & $<.001$ & 782 & 7.8 & 16.0 & $<.10$ & $<.1$ & $<.05$ & $<.02$ \\
\hline FP1 & $02-07-92$ & 1000 & .14 & 600 & 8.1 & .5 & .15 & $<.1$ & $<.05$ & $<.02$ \\
\hline FP2 & $02-04-92$ & 0950 & $<.001$ & 430 & 7.9 & 4.0 & $<.10$ & $<.1$ & $<.05$ & $<.02$ \\
\hline FP3 & $02-04-92$ & 1000 & .10 & 452 & 8.0 & 3.5 & $<.10$ & $<.1$ & $<.05$ & $<.02$ \\
\hline FP4 & $02-04-92$ & 1030 & .13 & 457 & 7.9 & 4.0 & $<.10$ & $<.1$ & $<.05$ & $<.02$ \\
\hline FP5 & $02-06-92$ & 1100 & .006 & 498 & 7.8 & 6.0 & $<.10$ & $<.1$ & $<.05$ & $<.02$ \\
\hline LB1 & $02-07-92$ & 0915 & .060 & 625 & 8.0 & .5 & $<.10$ & $<.1$ & $<.05$ & $<.02$ \\
\hline LB2 & $02-11-92$ & 0900 & .02 & 684 & 7.8 & 3.0 & $<.10$ & $<.1$ & $<.05$ & $<.02$ \\
\hline LB3 & $02-11-92$ & 1020 & .02 & 691 & 7.9 & 3.0 & $<.10$ & $<.1$ & $<.05$ & $<.02$ \\
\hline LB4 & $02-11-92$ & 1055 & .04 & 684 & 7.7 & 5.5 & $<.10$ & $<.1$ & $<.05$ & $<.02$ \\
\hline
\end{tabular}


Table 10. Values of selected physical properties and constituent concentrations of water samples collected during baseflow conditions-Continued

\begin{tabular}{|c|c|c|c|c|c|c|c|c|c|c|}
\hline $\begin{array}{c}\text { Slte } \\
\text { number } \\
\text { (fig. 2) }\end{array}$ & Date & TIme & $\begin{array}{c}\text { Discharge } \\
\left(\mathrm{ft}^{3} / \mathrm{s}\right)\end{array}$ & $\begin{array}{c}\text { Speciflc } \\
\text { conductance } \\
(\mu \mathrm{S} / \mathrm{cm})\end{array}$ & $\begin{array}{c}\mathrm{pH} \\
\text { (units) }\end{array}$ & $\begin{array}{c}\text { Temperature } \\
\left({ }^{\circ} \mathrm{C}\right)\end{array}$ & $\begin{array}{c}\text { Total } \\
\text { chlorinea } \\
\text { (mg/L) }\end{array}$ & $\begin{array}{l}\text { Total } \\
\text { coppera } \\
\text { (mg/L) }\end{array}$ & $\begin{array}{c}\text { Total } \\
\text { detergents a } \\
\text { (mg/L) }\end{array}$ & $\begin{array}{c}\text { Total } \\
\text { phenolsa } \\
\text { (mgll) }\end{array}$ \\
\hline \multirow[t]{2}{*}{ LB5 } & $02-03-92$ & 1100 & 0.001 & 1,230 & 8.2 & 6.5 & $<0.10$ & $<0.1$ & $<0.05$ & $<0.02$ \\
\hline & $02-03-92$ & 1530 & .001 & 1,240 & 8.2 & 7.0 & $<.10$ & $<.1$ & $<.05$ & $<.02$ \\
\hline \multirow[t]{2}{*}{ LB6 } & $02-03-92$ & 1112 & .001 & 902 & 8.5 & 7.0 & $<.10$ & $<.1$ & $<.05$ & $<.02$ \\
\hline & $02-03-92$ & 1530 & .001 & 904 & 8.5 & 7.0 & .50 & $<.1$ & $<.05$ & $<.02$ \\
\hline M1 & $01-21-92$ & 1000 & .43 & 825 & 8.4 & 1.5 & $<.10$ & $<.1$ & $<.05$ & $<.02$ \\
\hline M2 & $01-21-92$ & 1030 & .14 & 796 & 8.5 & 2.0 & .10 & $<.1$ & $<.05$ & $<.02$ \\
\hline M3 & $01-21-92$ & 1100 & .15 & 896 & 8.1 & 3.5 & $<.10$ & $<.1$ & $<.05$ & $<.02$ \\
\hline M4 & $01-21-92$ & 1120 & .09 & 926 & 8.3 & .5 & $<.10$ & $<.1$ & $<.05$ & $<.02$ \\
\hline M5 & $01-21-92$ & 1300 & .03 & 1,030 & 8.4 & 1.5 & $<.10$ & $<.1$ & $<.05$ & $<.02$ \\
\hline M6 & $01-21-92$ & 1330 & .03 & 1,100 & 8.3 & 3.5 & $<.10$ & $<.1$ & $<.05$ & $<.02$ \\
\hline M7 & $01-21-92$ & 1420 & .003 & 1,310 & 7.7 & 5.5 & $<.10$ & $<.1$ & $<.05$ & $<.02$ \\
\hline M8 & $01-21-92$ & 1430 & .02 & 1,480 & 8.2 & .5 & $<.10$ & $<.1$ & $<.05$ & $<.02$ \\
\hline M9 & $01-21-92$ & 1545 & .06 & 907 & 8.3 & 2.5 & $<.10$ & $<.1$ & $<.05$ & $<.02$ \\
\hline M10 & $01-24-92$ & 0735 & .001 & 1,200 & 7.4 & .5 & $<.10$ & $<.1$ & $<.05$ & $<.02$ \\
\hline M11 & $01-24-92$ & 0800 & .03 & 770 & 7.8 & 2.0 & $<.10$ & $<.1$ & $<.05$ & $<.02$ \\
\hline M12 & $01-24-92$ & 0845 & .01 & 722 & 7.4 & .5 & $<.10$ & $<.1$ & $<.05$ & $<.02$ \\
\hline M13 & $01-24-92$ & 1045 & .04 & 640 & 7.6 & 3.0 & $<.10$ & $<.1$ & $<.05$ & $<.02$ \\
\hline M14 & $01-27-92$ & 0945 & .06 & 1,040 & 7.7 & 8.5 & $<.10$ & $<.1$ & $<.05$ & $<.02$ \\
\hline M15 & $01-27-92$ & 1125 & .001 & 1,130 & 7.7 & 5.5 & $<.10$ & $<.1$ & $<.05$ & $<.02$ \\
\hline M16 & $01-27-92$ & 1330 & .01 & 883 & 7.5 & 7.0 & $<.10$ & $<.1$ & $<.05$ & $<.02$ \\
\hline M17 & $01-27-92$ & 1415 & .13 & 865 & 8.3 & 5.0 & $<.10$ & $<.1$ & $<.05$ & $<.02$ \\
\hline M18 & $01-27-92$ & -- & .05 & 1,030 & 8.4 & 7.5 & $<.10$ & $<.1$ & $<.05$ & $<.02$ \\
\hline \multirow[t]{2}{*}{ M19 } & $01-27-92$ & 1510 & .01 & 1,000 & 7.8 & 8.0 & $<.10$ & $<.1$ & $<.05$ & $<.02$ \\
\hline & $01-28-92$ & 0815 & .01 & 981 & 8.0 & 2.0 & .70 & $<.1$ & $<.05$ & $<.02$ \\
\hline M20 & $01-28-92$ & 0843 & .01 & 1,040 & 8.0 & 2.0 & $<.10$ & $<.1$ & $<.05$ & $<.02$ \\
\hline M21 & $01-28-92$ & 0913 & .005 & 886 & 8.4 & 3.0 & $<.10$ & $<.1$ & $<.05$ & $<.02$ \\
\hline M22 & $01-28-92$ & 1015 & .03 & 1,320 & 7.9 & 2.0 & $<.10$ & $<.1$ & $<.05$ & $<.02$ \\
\hline \multirow[t]{2}{*}{ M23 } & $01-28-92$ & 1045 & .003 & 1,130 & 8.2 & 4.5 & $<.10$ & $<.1$ & $<.05$ & $<.02$ \\
\hline & $01-29-92$ & 0820 & .002 & 1,130 & 8.0 & 5.0 & $<.10$ & $<.1$ & $<.05$ & $<.02$ \\
\hline M24 & $01-29-92$ & 0800 & .001 & 1,030 & 7.1 & 7.5 & $<.10$ & $<.1$ & $<.05$ & $<.02$ \\
\hline \multirow[t]{2}{*}{ M25 } & $01-29-92$ & 0845 & .004 & 1,360 & 7.6 & 8.5 & $<.10$ & $<.1$ & $<.05$ & $<.02$ \\
\hline & $01-30-92$ & 0815 & .004 & 1,380 & 7.7 & 10.0 & $<.10$ & $<.1$ & $<.05$ & $<.02$ \\
\hline \multirow[t]{2}{*}{ M26 } & $01-28-92$ & 0930 & .001 & 1,250 & 7.7 & 4.5 & $<.10$ & $<.1$ & $<.05$ & $<.02$ \\
\hline & $01-30-92$ & 0830 & $<.01$ & 1,320 & 7.7 & 5.5 & $<.10$ & $<.1$ & $<.05$ & $<.02$ \\
\hline \multirow[t]{2}{*}{ M27 } & $01-29-92$ & 0945 & .01 & 1,260 & 8.0 & 7.5 & $<.10$ & $<.1$ & $<.05$ & $<.02$ \\
\hline & $01-30-92$ & 0900 & .01 & 1,290 & 8.0 & 7.5 & $<.10$ & $<.1$ & $<.05$ & $<.02$ \\
\hline R1 & $10-08-91$ & 1020 & 10.1 & 901 & 6.8 & 21.0 & .10 & $<.1$ & $<.05$ & $<.02$ \\
\hline R2 & $10-08-91$ & 1030 & .14 & 489 & 6.9 & 13.5 & $<.10$ & $<.1$ & $<.05$ & $<.02$ \\
\hline R3 & $10-08-91$ & 1050 & .02 & 829 & 7.1 & 11.5 & .20 & $<.1$ & $<.05$ & $<.02$ \\
\hline R4 & $10-08-91$ & 1110 & -- & 908 & 7.3 & 24.0 & $<.10$ & $<.1$ & $<.05$ & $<.02$ \\
\hline R5 & $10-08-91$ & 1130 & .10 & 528 & 7.3 & 15.0 & .10 & $<.1$ & $<.05$ & $<.02$ \\
\hline R6 & $10-08-91$ & 1310 & .19 & 660 & 7.3 & 15.0 & .20 & $<.1$ & $<.05$ & $<.02$ \\
\hline R8 & $10-09-91$ & 0850 & .05 & 1,090 & 6.9 & 14.5 & $<.10$ & $<.1$ & $<.05$ & $<.02$ \\
\hline R9 & $10-09-91$ & 0900 & .03 & 982 & 6.8 & 14.5 & $<.10$ & $<.1$ & $<.05$ & $<.02$ \\
\hline R10 & $10-09-91$ & 1010 & .16 & 662 & 7.6 & 15.0 & $<.10$ & $<.1$ & $<.05$ & $<.02$ \\
\hline R11 & $10-09-91$ & 1010 & .02 & 1,070 & 7.8 & 16.0 & $<.10$ & $<.1$ & $<.05$ & $<.02$ \\
\hline R12 & $10-09-91$ & 1140 & .05 & 650 & 7.4 & 16.0 & $<.10$ & $<.1$ & $<.05$ & $<.02$ \\
\hline
\end{tabular}


Table 10. Values of selected physical properties and constituent concentrations of water samples collected during baseflow conditions-Continued

\begin{tabular}{|c|c|c|c|c|c|c|c|c|c|c|}
\hline $\begin{array}{c}\text { Slte } \\
\text { number } \\
\text { (fig. 2) }\end{array}$ & Date & TIme & $\begin{array}{c}\text { Discharge } \\
\left(\mathrm{ft}^{3} / \mathrm{s}\right)\end{array}$ & $\begin{array}{c}\text { Speciflc } \\
\text { conductance } \\
(\mu \mathrm{S} / \mathrm{cm})\end{array}$ & $\begin{array}{c}\text { pH } \\
\text { (units) }\end{array}$ & $\begin{array}{c}\text { Temperature } \\
\left({ }^{\circ} \mathrm{C}\right)\end{array}$ & $\begin{array}{c}\text { Total } \\
\text { chlorine } \\
\text { (mg/L) }\end{array}$ & $\begin{array}{c}\text { Total } \\
\text { copper } \\
\text { (mg/L) }\end{array}$ & $\begin{array}{c}\begin{array}{c}\text { Total } \\
\text { detergents } \\
\text { (mg/L) }\end{array} \\
\end{array}$ & $\begin{array}{c}\text { Total } \\
\text { phenols }^{a} \\
\text { (mg/L) }\end{array}$ \\
\hline R13 & $10-09-91$ & 1345 & 0.02 & 618 & 7.1 & 17.5 & $<0.10$ & $<0.1$ & $<0.05$ & $<0.02$ \\
\hline R14 & $10-09-91$ & 1450 & .05 & 637 & 7.6 & 21.5 & .10 & $<.1$ & $<.05$ & $<.02$ \\
\hline R15 & $10-10-91$ & 0830 & .03 & 863 & 7.6 & 13.5 & $<.10$ & $<.1$ & $<.05$ & $<.02$ \\
\hline R16 & $10-10-91$ & 1000 & .67 & 788 & 7.4 & 13.5 & $<.10$ & $<.1$ & $<.05$ & $<.02$ \\
\hline R17 & $10-10-91$ & 1040 & .01 & 550 & 8.5 & 16.0 & .15 & $<.1$ & $<.05$ & $<.02$ \\
\hline R18 & $10-10-91$ & 1110 & .02 & 788 & 8.0 & 15.0 & .30 & $<.1$ & $<.05$ & $<.02$ \\
\hline R19 & $10-10-91$ & 1253 & .09 & 932 & 8.0 & 14.5 & $<.10$ & $<.1$ & $<.05$ & $<.02$ \\
\hline \multirow[t]{2}{*}{ R20 } & $10-10-91$ & 1245 & .04 & 665 & 8.0 & 17.5 & .30 & $<.1$ & $<.05$ & $<.02$ \\
\hline & $10-11-91$ & 1010 & .04 & 546 & 8.5 & 18.5 & .80 & $<.1$ & $<.05$ & $<.02$ \\
\hline R21 & $10-10-91$ & 1335 & .09 & 881 & 8.0 & 16.0 & $<.10$ & $<.1$ & $<.05$ & $<.02$ \\
\hline R22 & $10-10-91$ & 1350 & .008 & 847 & 7.7 & 15.5 & $<.10$ & $<.1$ & $<.05$ & $<.02$ \\
\hline \multirow[t]{2}{*}{$\mathrm{R} 23$} & $10-10-91$ & 1410 & .04 & 771 & 7.9 & 19.5 & .10 & $<.1$ & $<.05$ & $<.02$ \\
\hline & $10-11-91$ & 1050 & .03 & 728 & 7.4 & 17.5 & $<.10$ & $<.1$ & $<.05$ & $<.02$ \\
\hline \multirow[t]{2}{*}{ R24 } & $10-10-91$ & 1445 & .03 & 1,560 & 7.3 & 17.0 & .10 & $<.1$ & $<.05$ & $<.02$ \\
\hline & $10-11-91$ & 1035 & .03 & 1,560 & 7.3 & 18.0 & $<.10$ & $<.1$ & $<.05$ & $<.02$ \\
\hline R25 & $10-11-91$ & 0945 & .007 & 875 & 7.9 & 13.5 & $<.10$ & $<.1$ & $<.05$ & $<.02$ \\
\hline R26 & $10-11-91$ & 0945 & .01 & 772 & 8.0 & 13.5 & $<.10$ & $<.1$ & $<.05$ & $<.02$ \\
\hline R27 & $10-11-91$ & 1125 & .01 & 704 & 7.7 & 19.0 & .20 & $<.1$ & $<.05$ & $<.02$ \\
\hline R50 & $10-16-91$ & 1220 & .003 & 776 & 8.1 & 12.5 & $<.10$ & $<.1$ & $<.05$ & $<.02$ \\
\hline R51 & $10-16-91$ & 1235 & .04 & 830 & 7.9 & 15.0 & $<.10$ & $<.1$ & $<.05$ & $<.02$ \\
\hline R52 & $10-16-91$ & 1245 & .03 & 825 & 7.9 & 15.0 & $<.10$ & $<.1$ & $<.05$ & $<.02$ \\
\hline R53 & $10-16-91$ & 1415 & .03 & 922 & 7.9 & 12.5 & $<.10$ & $<.1$ & $<.05$ & $<.02$ \\
\hline R54 & $10-16-91$ & -- & .03 & 875 & 8.1 & 12.0 & $<.10$ & $<.1$ & $<.05$ & $<.02$ \\
\hline \multirow[t]{2}{*}{ R60 } & $02-27-92$ & 0934 & .024 & 533 & 7.6 & 18.5 & .15 & $<.1$ & $<.05$ & $<.02$ \\
\hline & $02-27-92$ & 1516 & .02 & 537 & 7.6 & 19.5 & .10 & $<.1$ & $<.05$ & $<.02$ \\
\hline \multirow[t]{2}{*}{ R61 } & $02-27-92$ & 0910 & .003 & 773 & 9.8 & 10.0 & .10 & $<.1$ & $<.05$ & $<.02$ \\
\hline & $02-27-92$ & 1454 & .009 & 829 & 8.7 & 11.0 & .10 & $<.1$ & $<.05$ & $<.02$ \\
\hline S1 & $01-15-92$ & 1245 & .20 & 596 & 6.8 & 2.0 & .10 & $<.1$ & $<.05$ & $<.02$ \\
\hline $\mathbf{S} 2$ & $01-15-92$ & 1245 & .04 & 694 & 7.3 & .5 & $<.10$ & $<.1$ & $<.05$ & $<.02$ \\
\hline S3 & $01-15-92$ & 0830 & .19 & 574 & 6.7 & 3.0 & .10 & $<.1$ & $<.05$ & $<.02$ \\
\hline S4 & $01-15-92$ & 1340 & .001 & 1,080 & 6.8 & .5 & $<.10$ & $<.1$ & $<.05$ & $<.02$ \\
\hline S5 & $01-15-92$ & 1400 & .001 & 1,260 & 7.0 & 3.0 & $<.10$ & $<.1$ & $<.05$ & $<.02$ \\
\hline S6 & $01-16-92$ & 0830 & $<.20$ & 1,230 & 8.1 & 1.0 & $<.10$ & $<.1$ & $<.05$ & $<.02$ \\
\hline S7 & $01-16-92$ & 0920 & $<.01$ & 1,280 & 8.0 & .5 & $<.10$ & $<.1$ & $<.05$ & $<.02$ \\
\hline S8 & $01-16-92$ & 1000 & $<.10$ & 670 & 8.0 & 1.5 & $<.10$ & $<.1$ & $<.05$ & $<.02$ \\
\hline S9 & $01-16-92$ & 1030 & $<.10$ & 642 & 7.6 & 3.5 & $<.10$ & $<.1$ & $<.05$ & $<.02$ \\
\hline $\mathrm{S} 10$ & $01-16-92$ & 1100 & $<.20$ & -- & 8.2 & 2.0 & $<.10$ & $<.1$ & $<.05$ & $<.02$ \\
\hline \multirow[t]{2}{*}{ S11 } & $01-16-92$ & 1120 & $<.01$ & 853 & 7.8 & 7.0 & .15 & $<.1$ & $<.05$ & $<.02$ \\
\hline & $01-17-92$ & 0845 & .009 & 858 & 7.5 & 7.0 & .15 & $<.1$ & $<.05$ & $<.02$ \\
\hline $\mathrm{S} 12$ & $01-16-92$ & 1200 & $<.001$ & 1,010 & 7.5 & 3.0 & $<.10$ & $<.1$ & $<.05$ & $<.02$ \\
\hline S13 & $01-17-92$ & 0915 & .23 & 674 & 8.2 & 7.5 & $<.10$ & $<.1$ & $<.05$ & $<.02$ \\
\hline S14 & $01-17-92$ & 1020 & .06 & 698 & 8.1 & 12.5 & .40 & $<.1$ & $<.05$ & $<.02$ \\
\hline S15 & $01-17-92$ & 1100 & .04 & 979 & 7.6 & 9.0 & $<.10$ & $<.1$ & $<.05$ & $<.02$ \\
\hline S16 & $01-17-92$ & 1145 & .007 & 854 & 8.0 & 1.5 & .20 & $<.1$ & $<.05$ & $<.02$ \\
\hline \multirow[t]{3}{*}{ S17 } & $01-22-92$ & 0830 & .01 & 507 & 9.2 & 12.0 & .20 & $<.1$ & $<.05$ & $<.02$ \\
\hline & $01-17-92$ & 1230 & .01 & 550 & 9.3 & 11.0 & .50 & $<.1$ & $<.05$ & $<.02$ \\
\hline & $01-21-92$ & 0830 & .01 & 534 & 9.4 & 10.5 & .50 & $<.1$ & $<.05$ & $<.02$ \\
\hline S18 & $01-17-92$ & 1300 & .006 & 1,040 & 8.1 & 4.0 & $<.10$ & $<.1$ & $<.05$ & $<.02$ \\
\hline
\end{tabular}


Table 10. Values of selected physical properties and constituent concentrations of water samples collected during baseflow conditions-Continued

\begin{tabular}{|c|c|c|c|c|c|c|c|c|c|c|}
\hline $\begin{array}{c}\text { Site } \\
\text { number } \\
\text { (fig. 2) }\end{array}$ & Date & TIme & $\begin{array}{c}\text { Discharge } \\
\left(\mathrm{ft}^{3} / \mathrm{s}\right)\end{array}$ & $\begin{array}{c}\text { Speciflc } \\
\text { conductance } \\
(\mu \mathrm{S} / \mathrm{cm})\end{array}$ & $\underset{\text { pH }}{\text { (unlts) }}$ & $\begin{array}{c}\text { Temperature } \\
\left({ }^{\circ} \mathrm{C}\right)\end{array}$ & $\begin{array}{c}\text { Total } \\
\text { chlorine } \\
\text { (mg/L) }\end{array}$ & $\begin{array}{l}\text { Total } \\
\text { coppera } \\
\text { (mg/L) }\end{array}$ & $\begin{array}{l}\text { Total } \\
\text { detergents } \\
(\mathbf{m g} / \mathrm{L})\end{array}$ & $\begin{array}{c}\text { Total } \\
\text { phenols }^{a} \\
(\mathrm{mg} / \mathrm{l})\end{array}$ \\
\hline S19 & $01-17-92$ & 1330 & 0.02 & 1,210 & 7.7 & 11.0 & $<0.10$ & $<0.1$ & 0.30 & $<0.02$ \\
\hline $\mathbf{S} 20$ & $01-21-92$ & 0915 & .15 & 527 & 9.2 & 15.5 & .90 & $<.1$ & $<.05$ & $<.02$ \\
\hline SB1 & $10-08-91$ & 1030 & .38 & 864 & 7.8 & 12.0 & $<.10$ & $<.1$ & $<.05$ & $<.02$ \\
\hline SB2 & $10-08-91$ & 1130 & .40 & 772 & 7.8 & 12.5 & $<.10$ & $<.1$ & $<.05$ & $<.02$ \\
\hline SB3 & $10-08-91$ & 1210 & .08 & 667 & 8.1 & 14.0 & $<.10$ & $<.1$ & $<.05$ & $<.02$ \\
\hline SB4 & $10-08-91$ & 1245 & .10 & 671 & 8.2 & 14.5 & $<.10$ & $<.1$ & $<.05$ & $<.02$ \\
\hline SB5 & $10-08-91$ & 1345 & .08 & 686 & 7.9 & 16.5 & .10 & $<.1$ & $<.05$ & $<.02$ \\
\hline SB6 & $10-08-91$ & 1415 & .05 & 694 & 7.9 & 18.0 & $<.10$ & $<.1$ & $<.05$ & $<.02$ \\
\hline SB7 & $10-08-91$ & 1435 & .02 & 750 & 8.1 & 17.0 & .10 & $<.1$ & $<.05$ & $<.02$ \\
\hline SB8 & $10-09-91$ & 0900 & .07 & 711 & 8.2 & 13.5 & $<.10$ & $<.1$ & $<.05$ & $<.02$ \\
\hline SB9 & $10-09-91$ & 1140 & .33 & 703 & 7.6 & 15.5 & $<.10$ & $<.1$ & $<.05$ & $<.02$ \\
\hline SB 10 & $10-09-91$ & 1300 & .24 & 734 & 7.7 & 15.0 & $<.10$ & $<.1$ & $<.05$ & $<.02$ \\
\hline SB11 & $10-09-91$ & 1400 & .15 & 821 & 7.9 & 16.0 & $<.10$ & $<.1$ & $<.05$ & $<.02$ \\
\hline SB12 & $10-09-91$ & 1445 & .38 & 667 & 7.7 & 17.5 & $<.10$ & $<.1$ & $<.05$ & $<.02$ \\
\hline SB13 & $10-10-91$ & 0955 & $<.03$ & 506 & 8.8 & 15.5 & $<.10$ & $<.1$ & $<.05$ & $<.02$ \\
\hline SB15 & $10-10-91$ & 1415 & .07 & 1,250 & 7.8 & 16.5 & $<.10$ & $<.1$ & $<.05$ & $<.02$ \\
\hline SB16 & $10-10-91$ & 1320 & .02 & 546 & 7.6 & 19.5 & $<.10$ & $<.1$ & $<.05$ & $<.02$ \\
\hline SB17 & $10-11-91$ & 0850 & .14 & 858 & 7.5 & 13.0 & $<.10$ & $<.1$ & $<.05$ & $<.02$ \\
\hline SB18 & $10-11-91$ & 0930 & .08 & 1,160 & 7.9 & 13.5 & -. & $<.1$ & $<.05$ & $<.02$ \\
\hline SB19 & $10-11-91$ & 1010 & .02 & 576 & 8.0 & 13.5 & $<.10$ & $<.1$ & $<.05$ & $<.02$ \\
\hline SB20 & $10-11-91$ & 1045 & .06 & 1,220 & 8.0 & 14.5 & $<.10$ & $<.1$ & $<.05$ & $<.02$ \\
\hline SB21 & $10-11-91$ & 1120 & .04 & 1,730 & 8.3 & 14.0 & $<.10$ & $<.1$ & $<.05$ & $<.02$ \\
\hline SB22 & $10-15-91$ & 0933 & .02 & 2,530 & 8.0 & 12.0 & $<.10$ & $<.1$ & $<.05$ & $<.02$ \\
\hline SB23 & $10-15-91$ & 1030 & .006 & 912 & 8.1 & 13.0 & $<.10$ & $<.1$ & $<.05$ & $<.02$ \\
\hline SB24 & $10-15-91$ & 1110 & .02 & 1,540 & 8.2 & 14.0 & $<.10$ & $<.1$ & $<.05$ & $<.02$ \\
\hline SB25 & $10-15-91$ & 1215 & .08 & 1,600 & 8.6 & 13.5 & $<.10$ & $<.1$ & $<.05$ & $<.02$ \\
\hline SB26 & $10-15-91$ & 1435 & .01 & 1,040 & 8.0 & 14.0 & $<.10$ & $<.1$ & $<.05$ & $<.02$ \\
\hline SB27 & $10-16-91$ & 0920 & .02 & 1,080 & 8.1 & 10.0 & $<.10$ & $<.1$ & $<.05$ & $<.02$ \\
\hline WFP1 & $02-05-92$ & 0855 & .16 & 325 & 8.7 & 1.5 & $<.10$ & $<.1$ & $<.05$ & $<.02$ \\
\hline WFP2 & $02-05-92$ & 0920 & 1.02 & 693 & 8.2 & .5 & $<.10$ & $<.1$ & $<.05$ & $<.02$ \\
\hline WFP3 & $02-05-92$ & 1010 & .29 & 1,000 & 8.3 & .5 & $<.10$ & $<.1$ & $<.05$ & $<.02$ \\
\hline WFP4 & $02-05-92$ & 1030 & .15 & 513 & 8.1 & 1.0 & $<.10$ & $<.1$ & $<.05$ & $<.02$ \\
\hline WFP5 & $02-05-92$ & 1045 & .26 & 531 & 8.4 & 1.0 & $<.10$ & $<.1$ & $<.05$ & $<.02$ \\
\hline WFP6 & $02-06-92$ & 0810 & .03 & 922 & 7.8 & 1.0 & $<.10$ & $<.1$ & $<.05$ & $<.02$ \\
\hline WFP7 & $02-06-92$ & 0845 & .23 & 1,320 & 8.2 & 1.5 & $<.10$ & $<.1$ & $<.05$ & $<.02$ \\
\hline WFP8 & $02-06-92$ & 0920 & .10 & 616 & 7.9 & 1.5 & $<.10$ & $<.1$ & $<.05$ & $<.02$ \\
\hline WFP9 & $02-06-92$ & 1000 & .05 & 532 & 8.2 & 1.5 & $<.10$ & $<.1$ & $<.05$ & $<.02$ \\
\hline WFP10 & $02-06-92$ & 1020 & .08 & 413 & 7.4 & 6.5 & $<.10$ & $<.1$ & $<.05$ & $<.02$ \\
\hline
\end{tabular}

${ }^{\text {a }}$ Concentrations are considered semi-quantitative. 


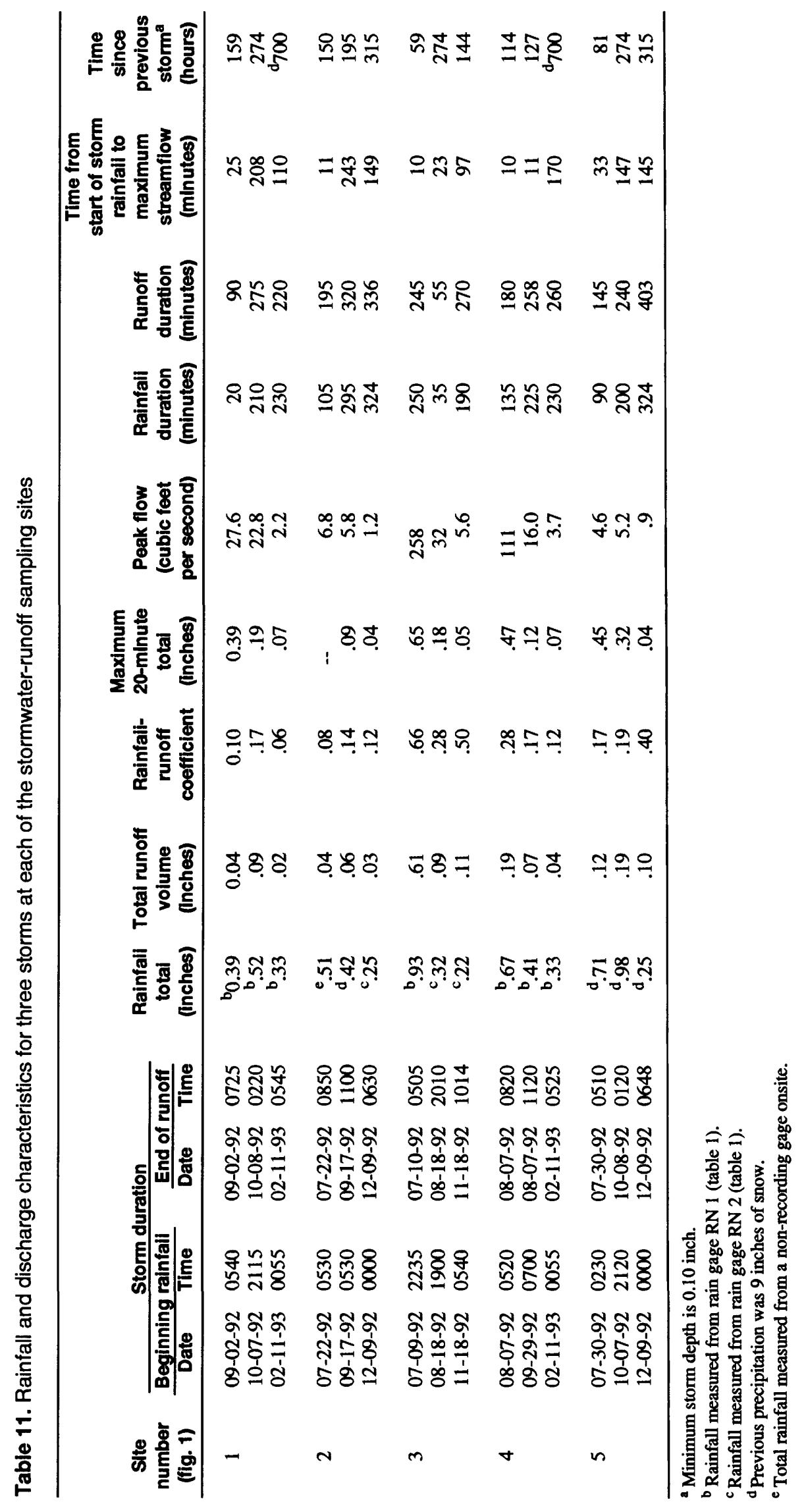




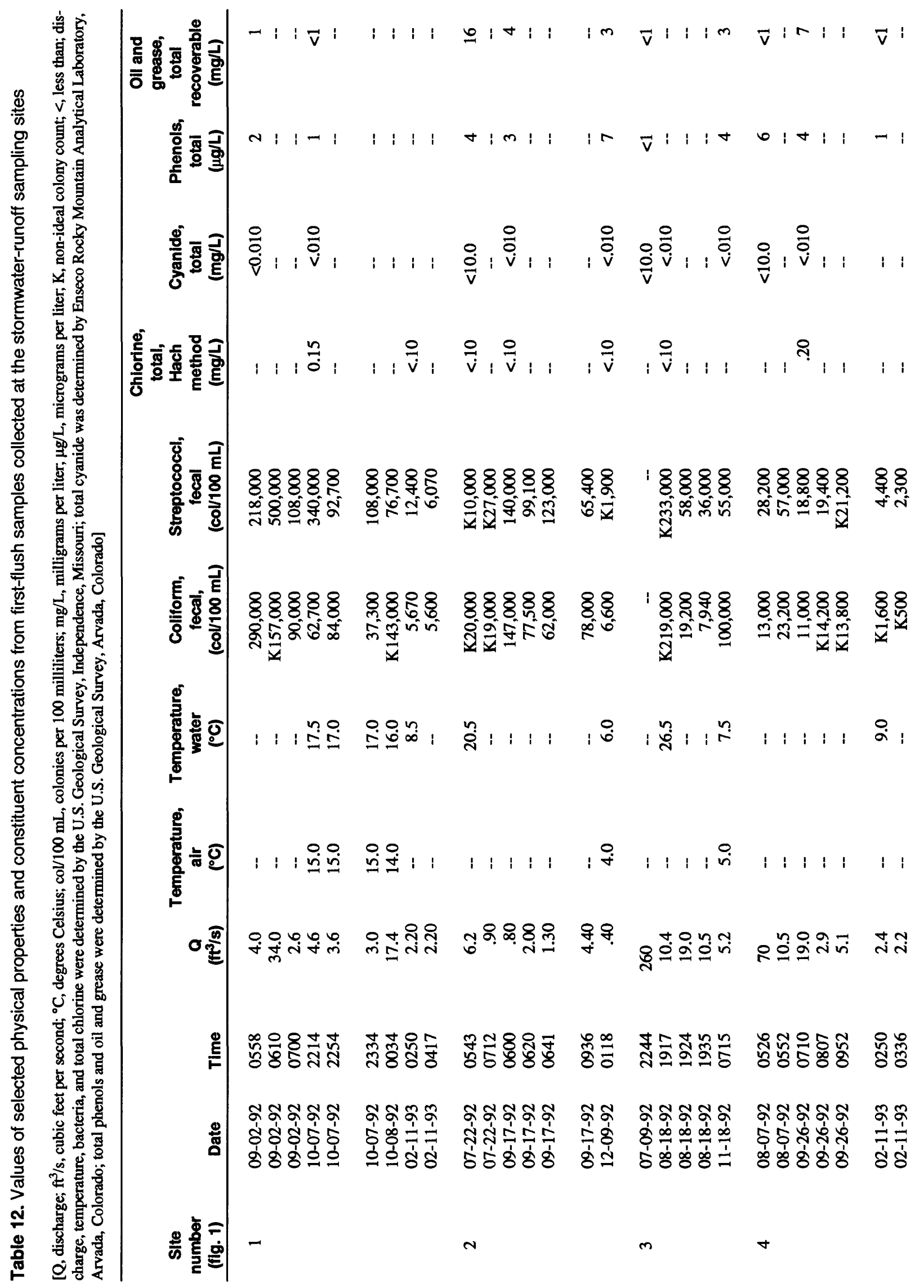




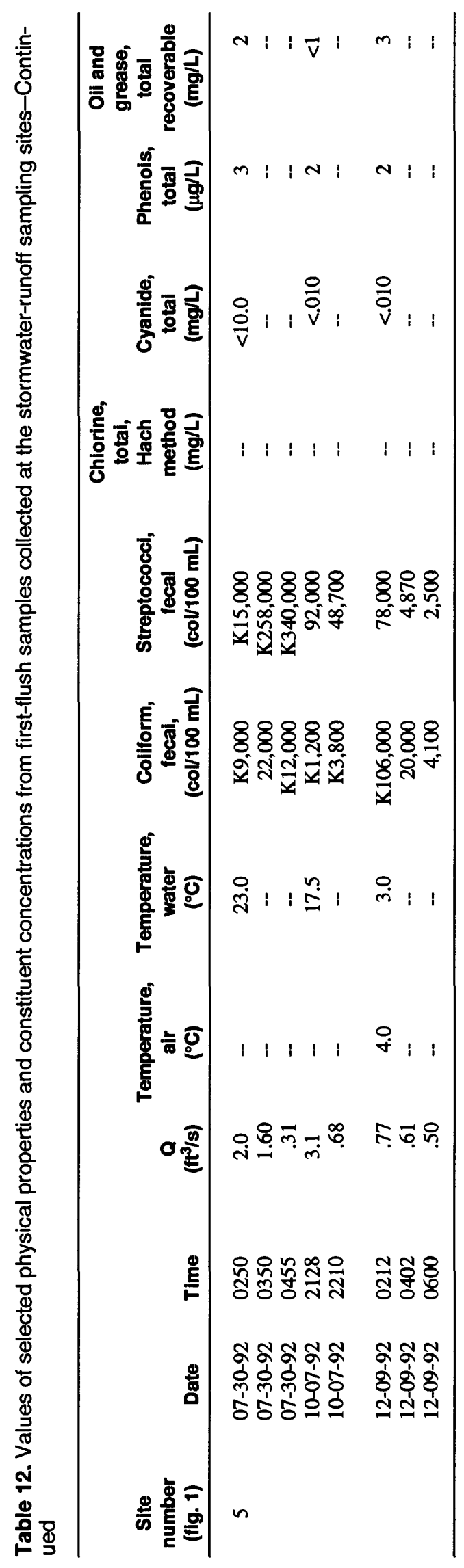

45 


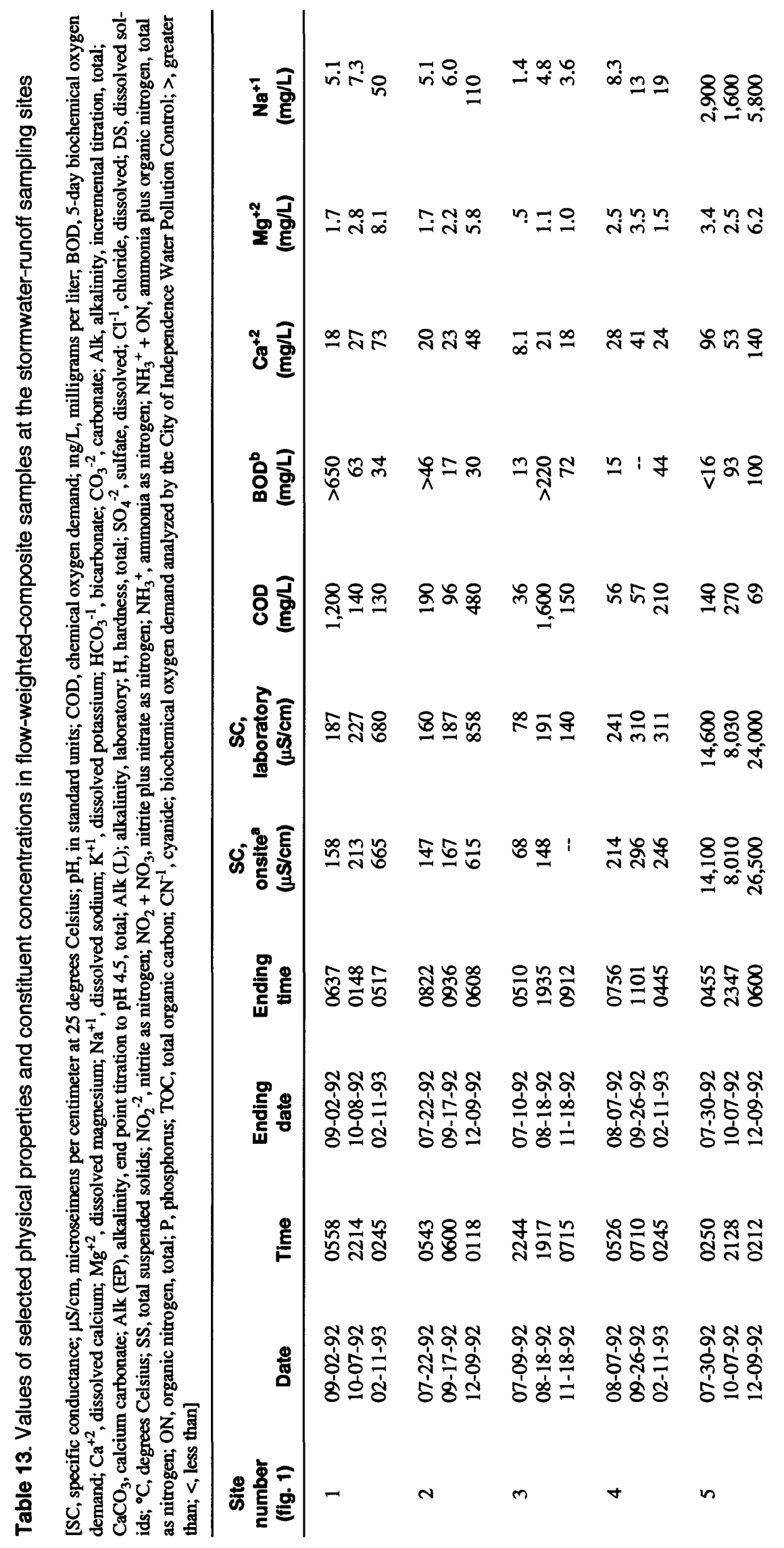




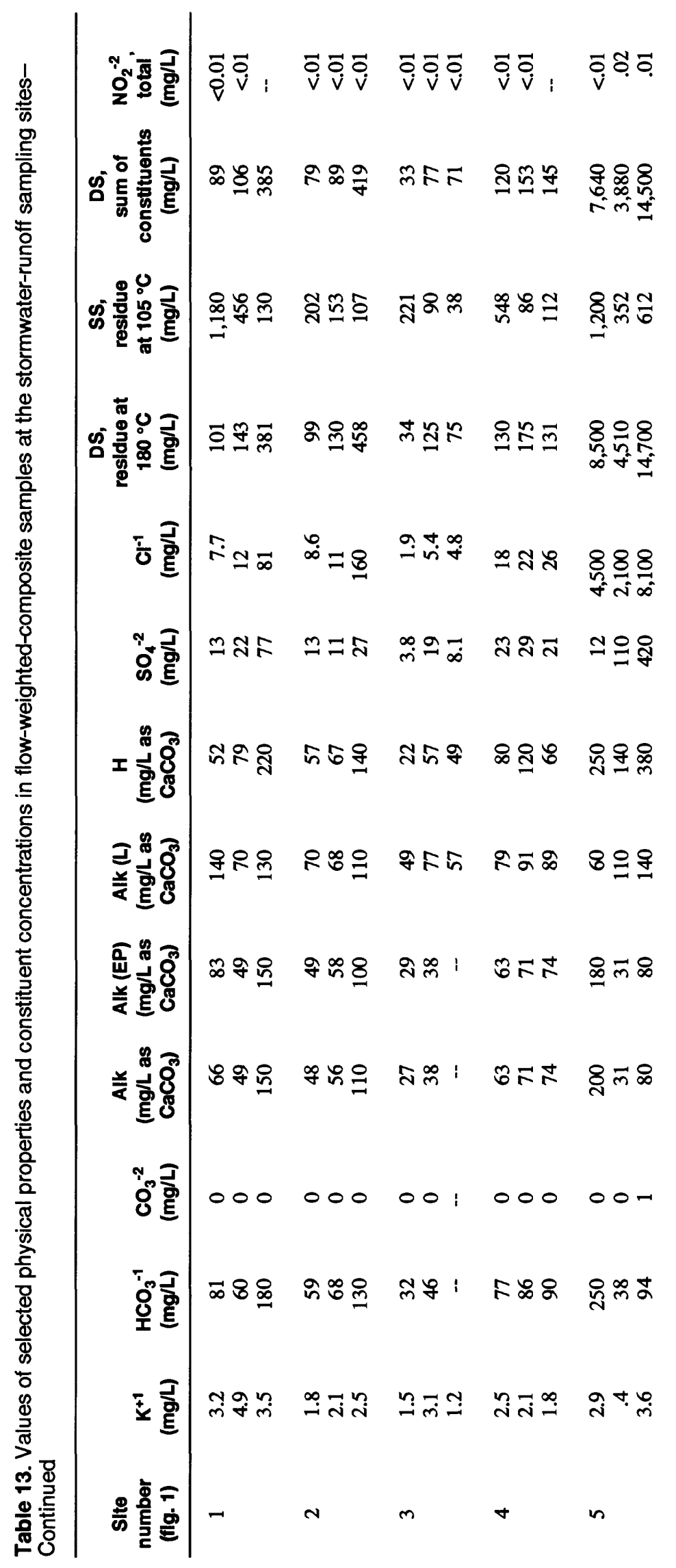




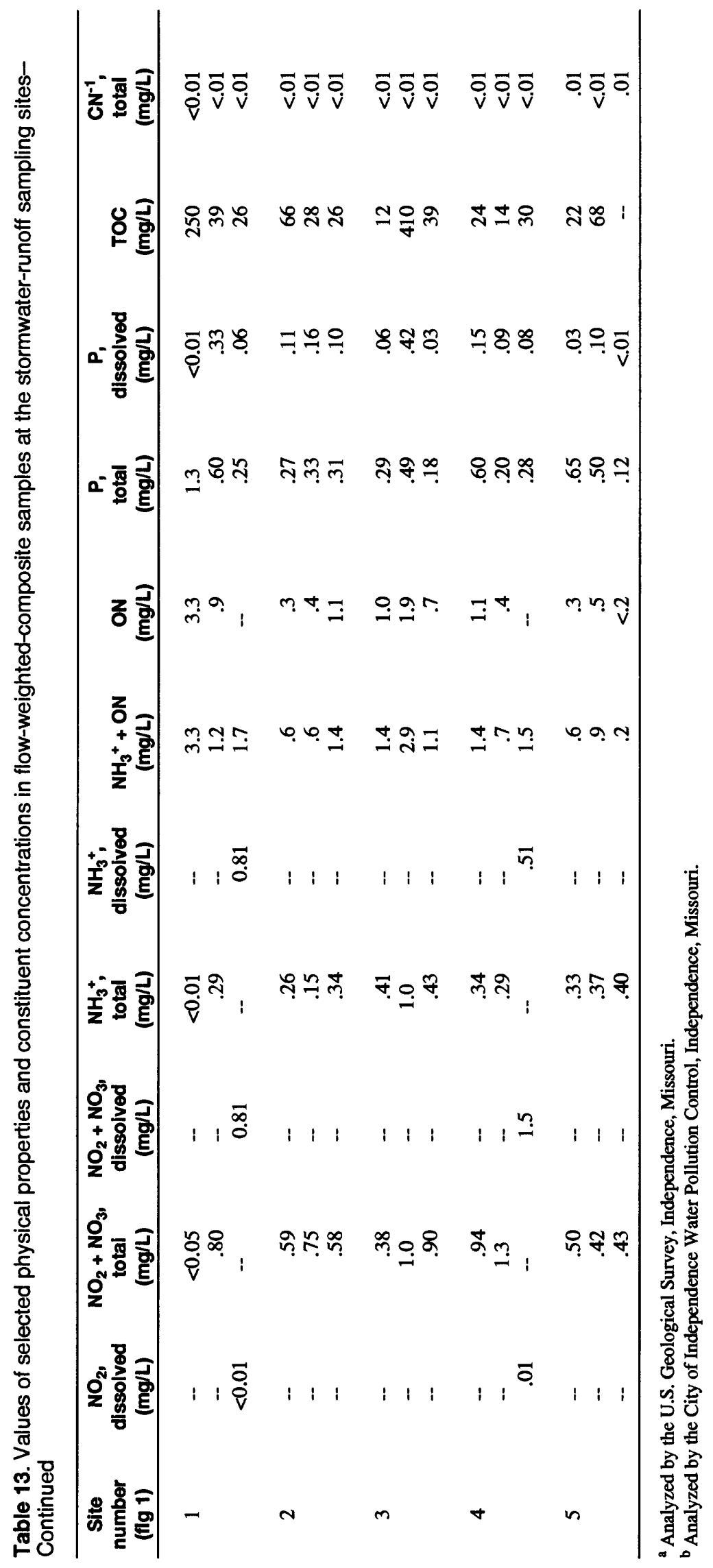




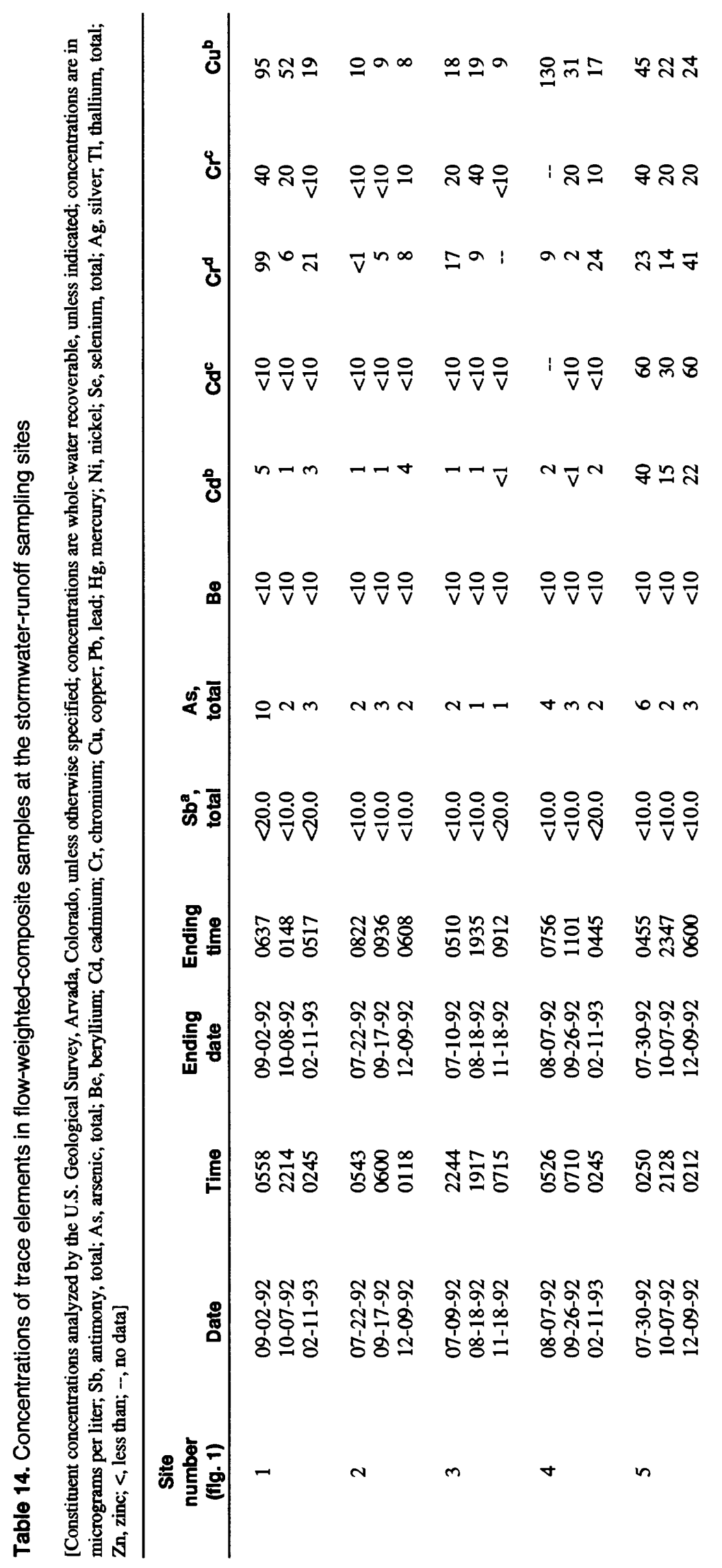




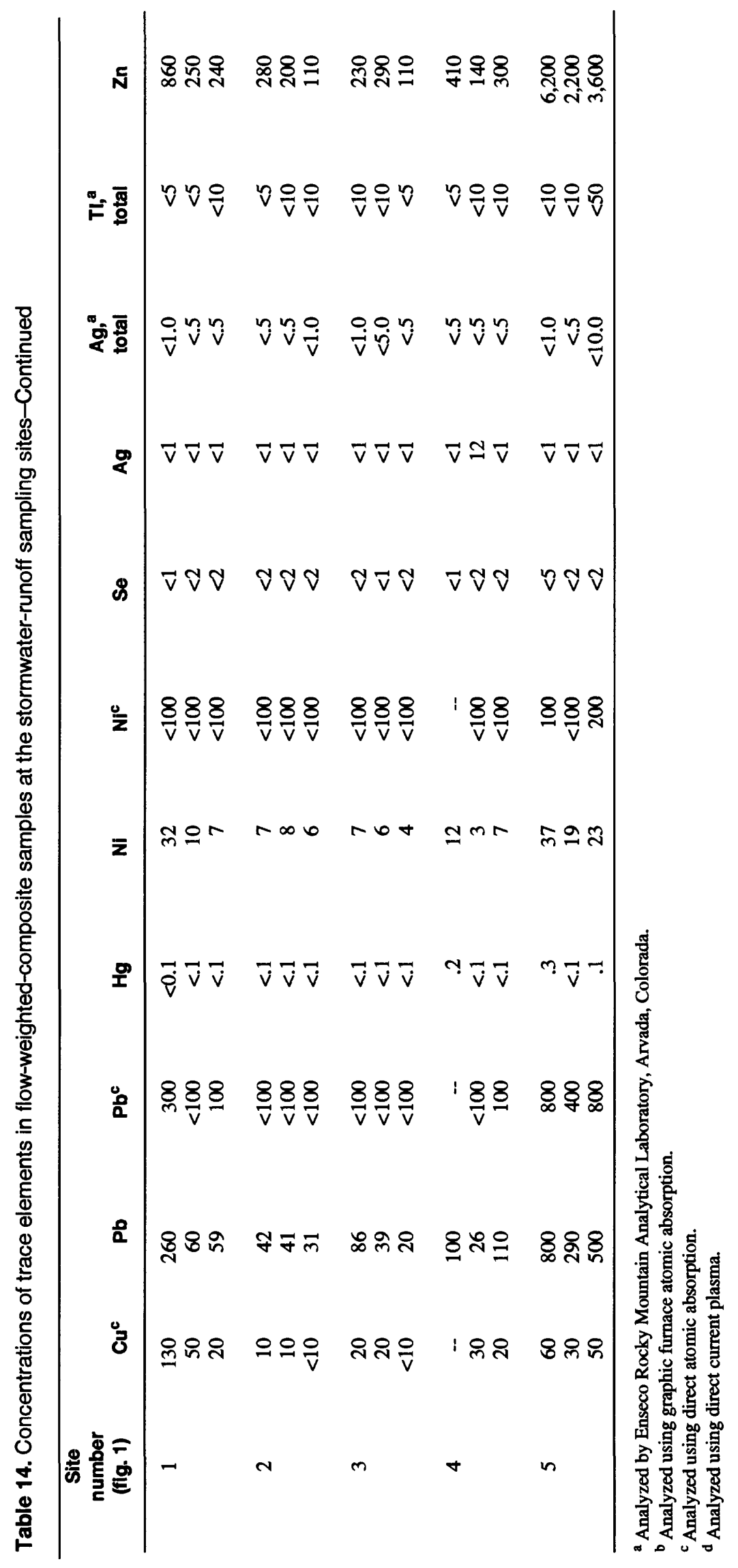




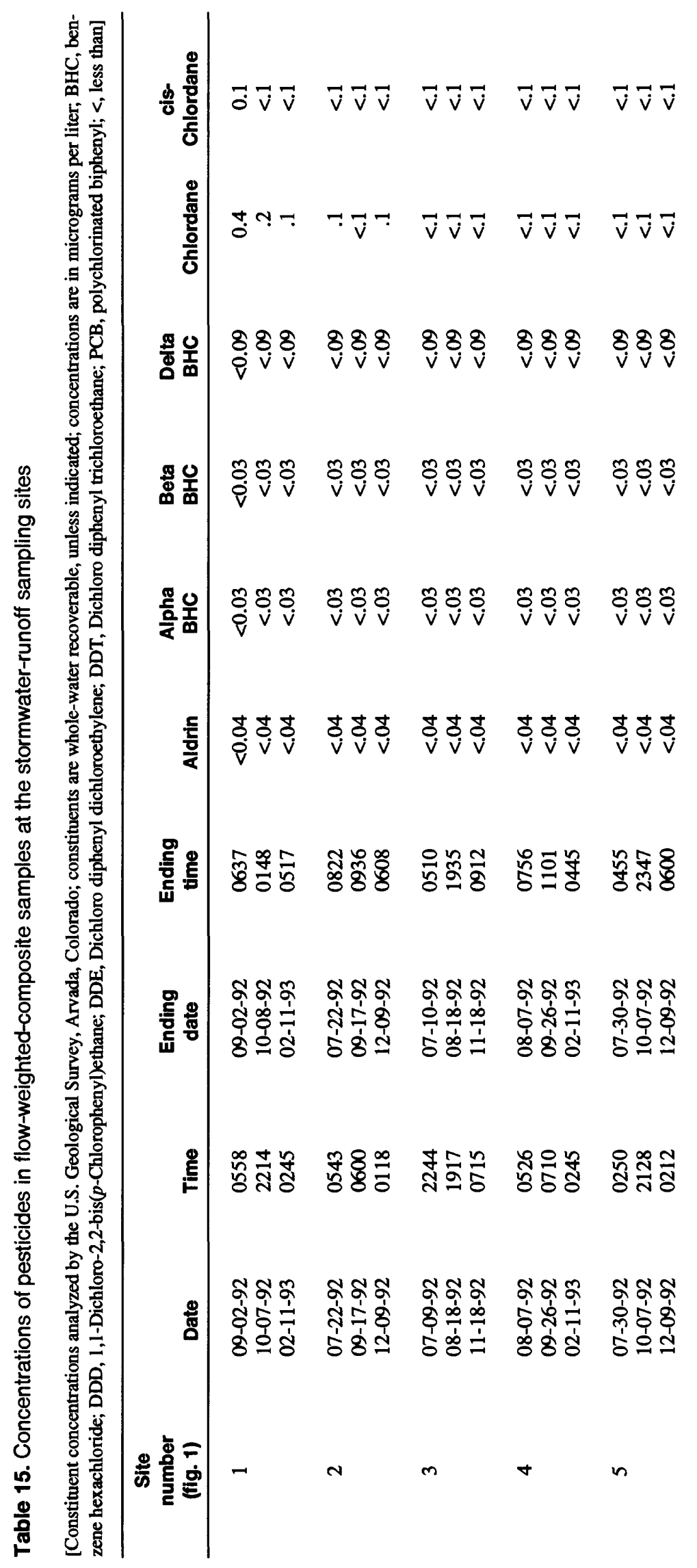




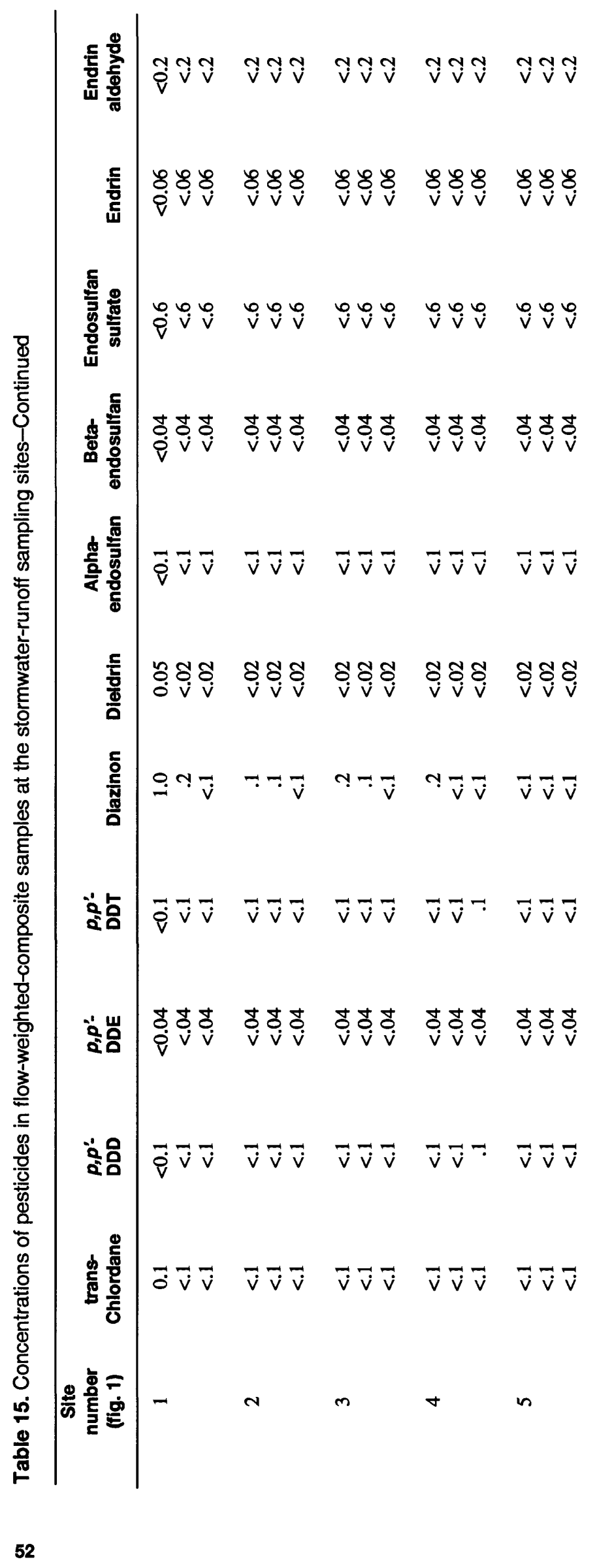




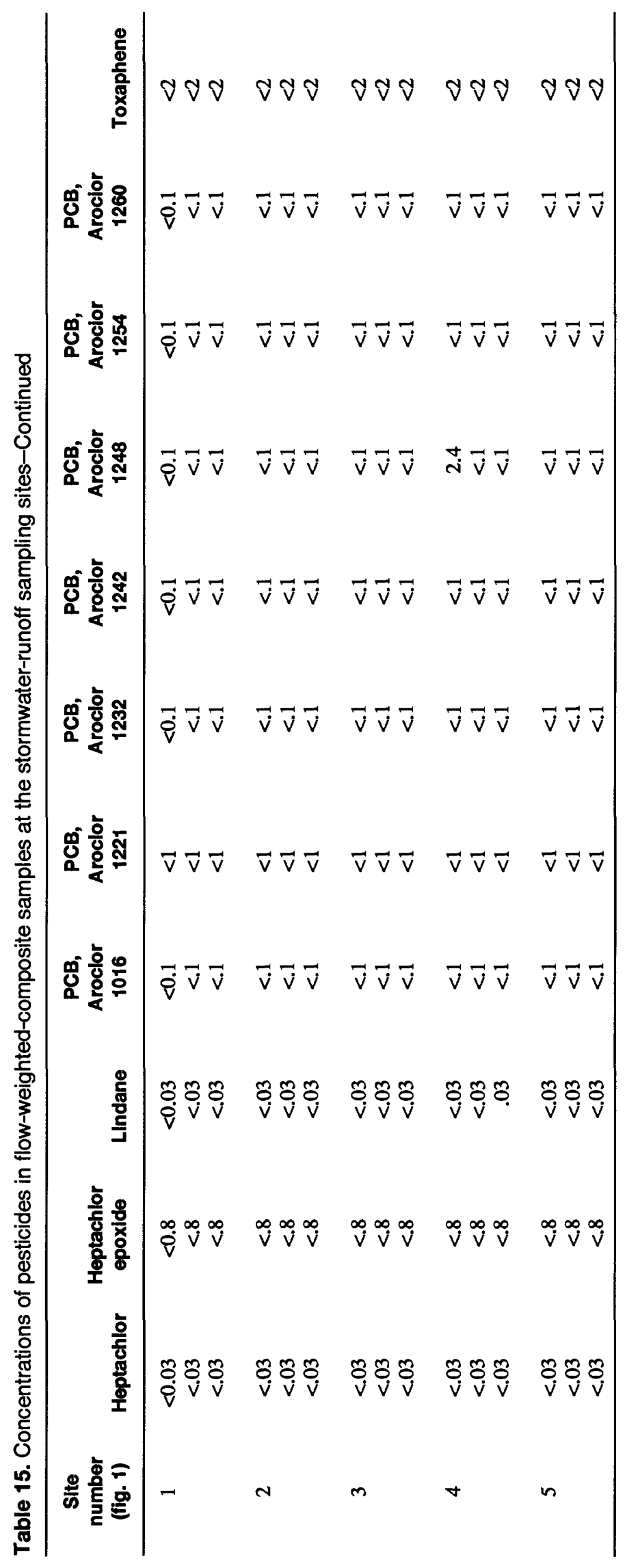




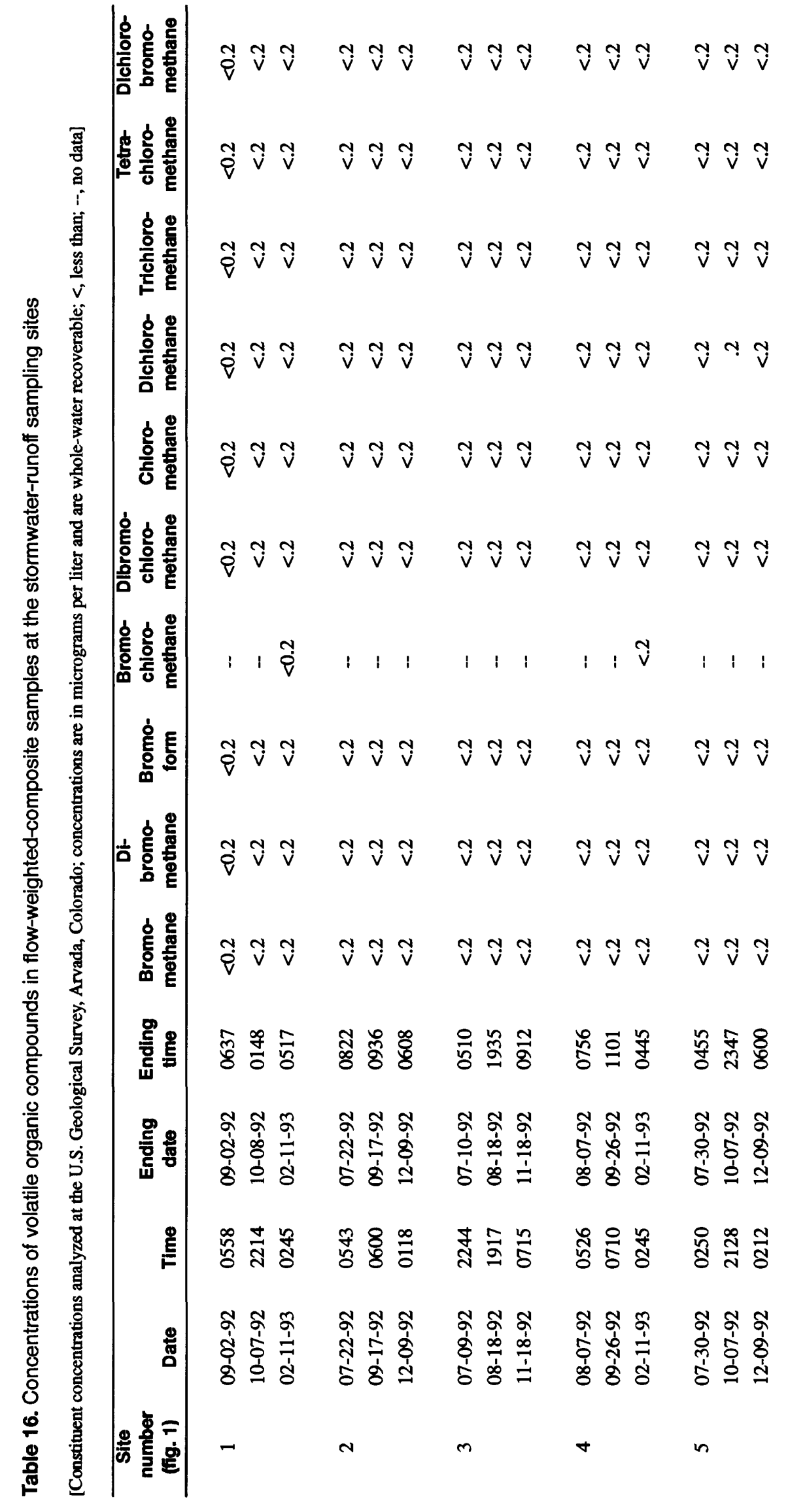




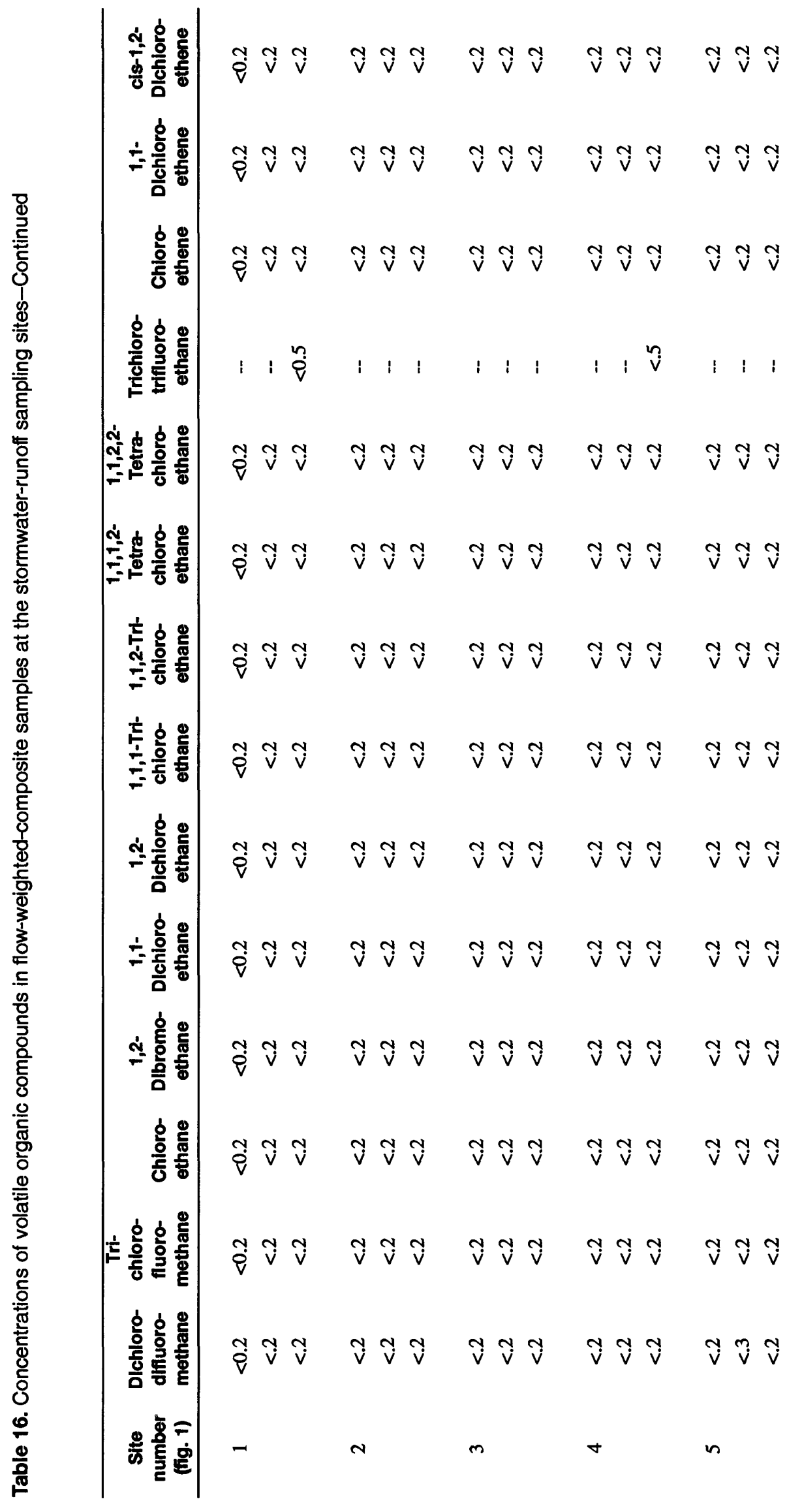




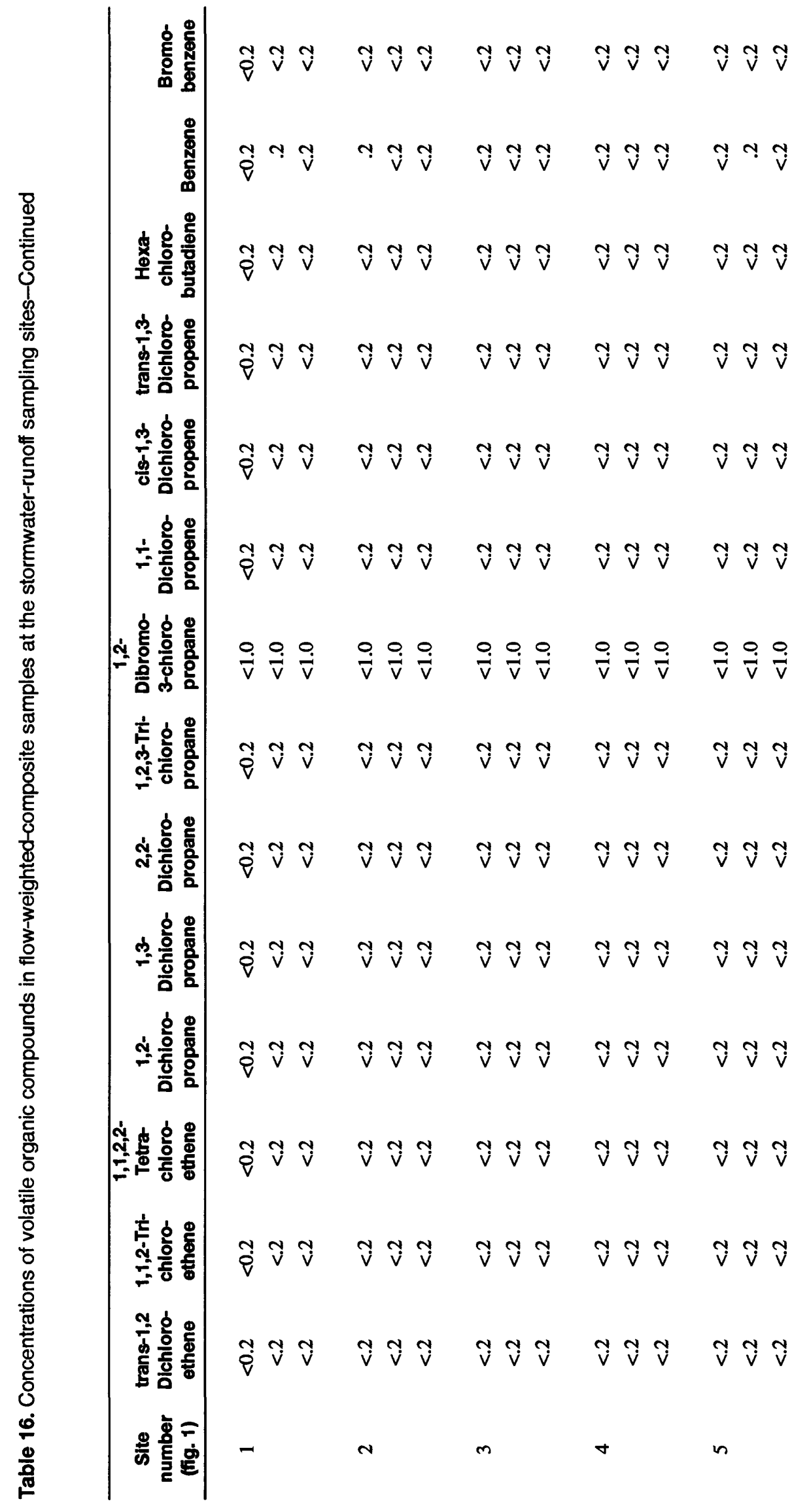




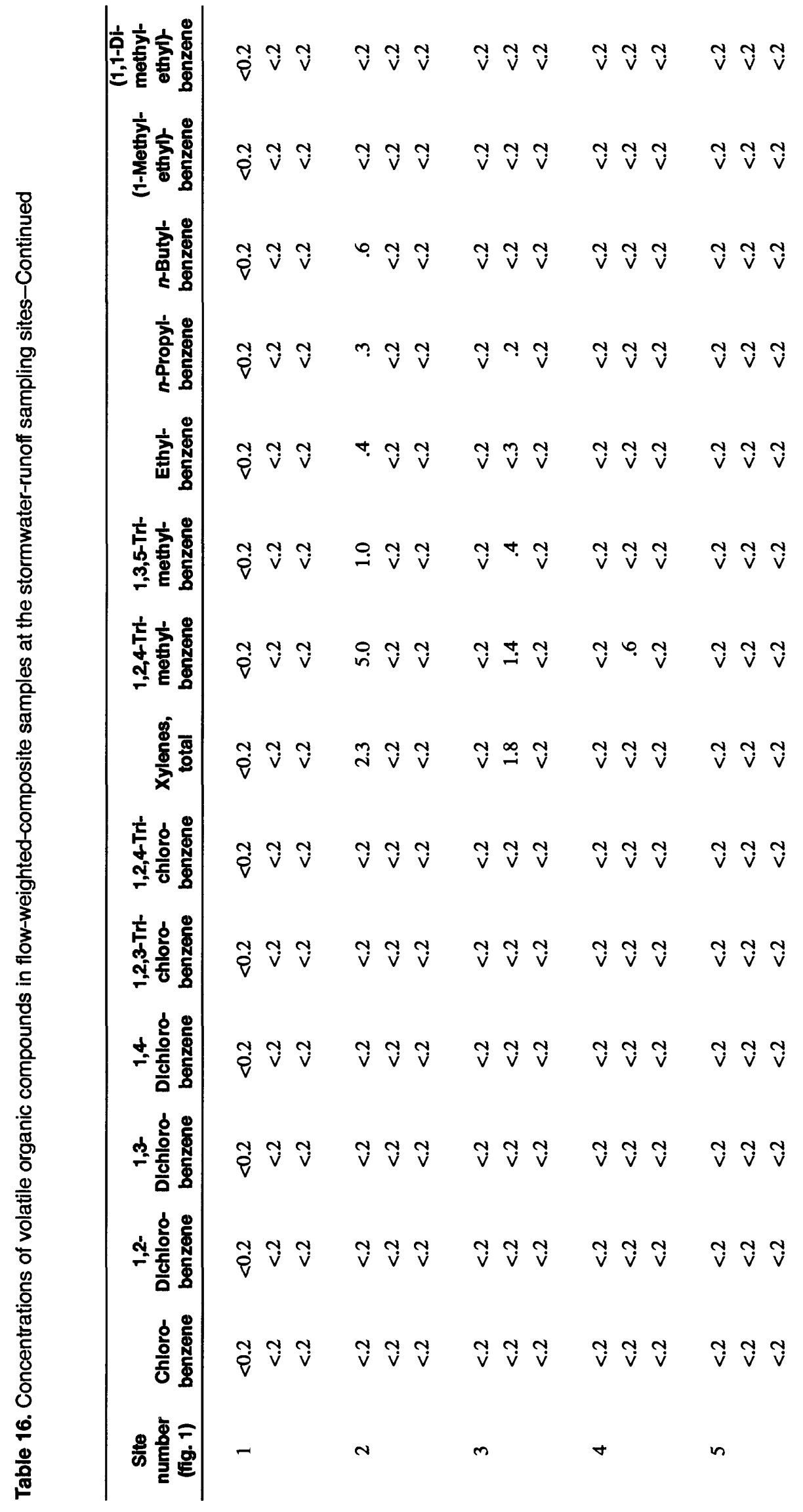




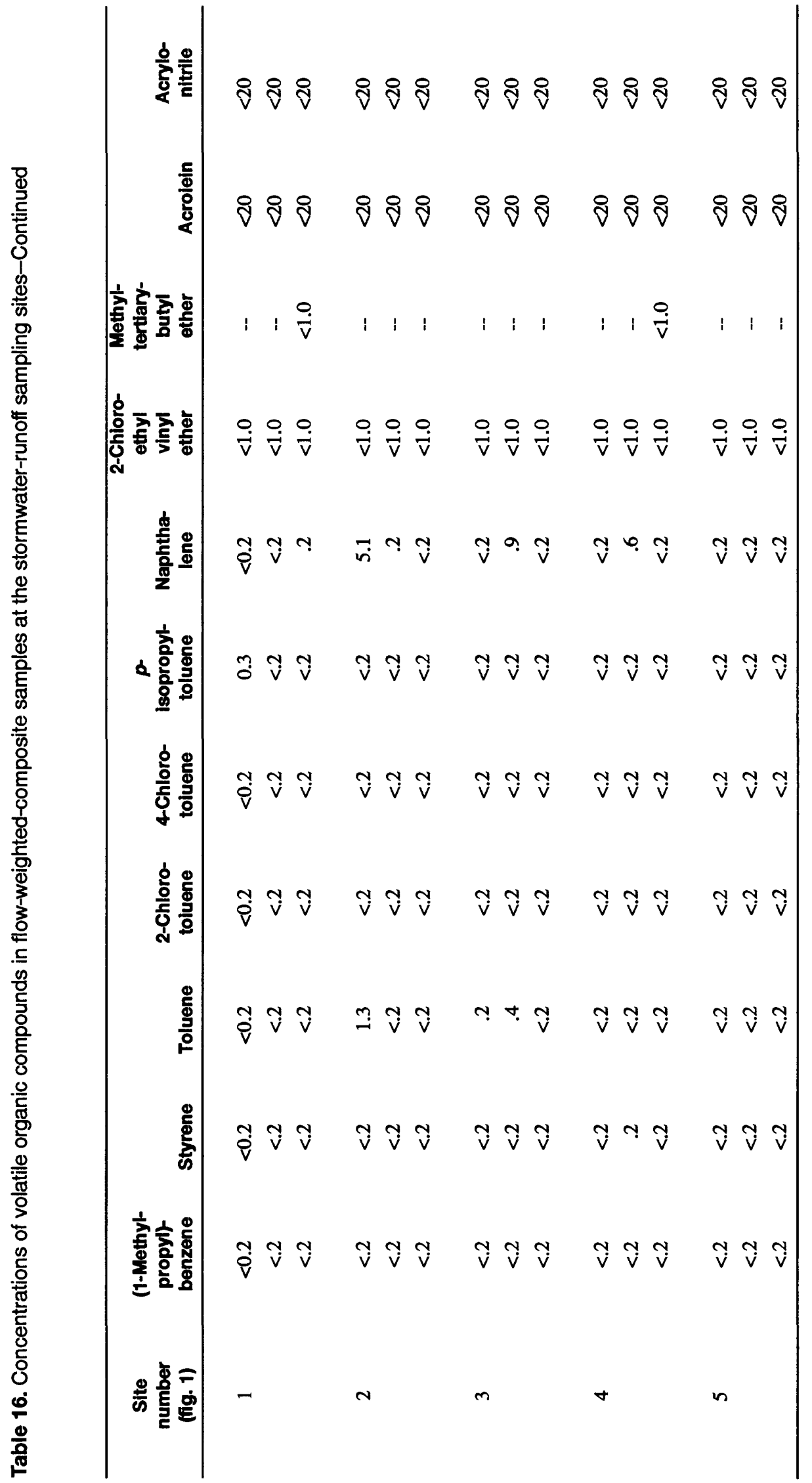




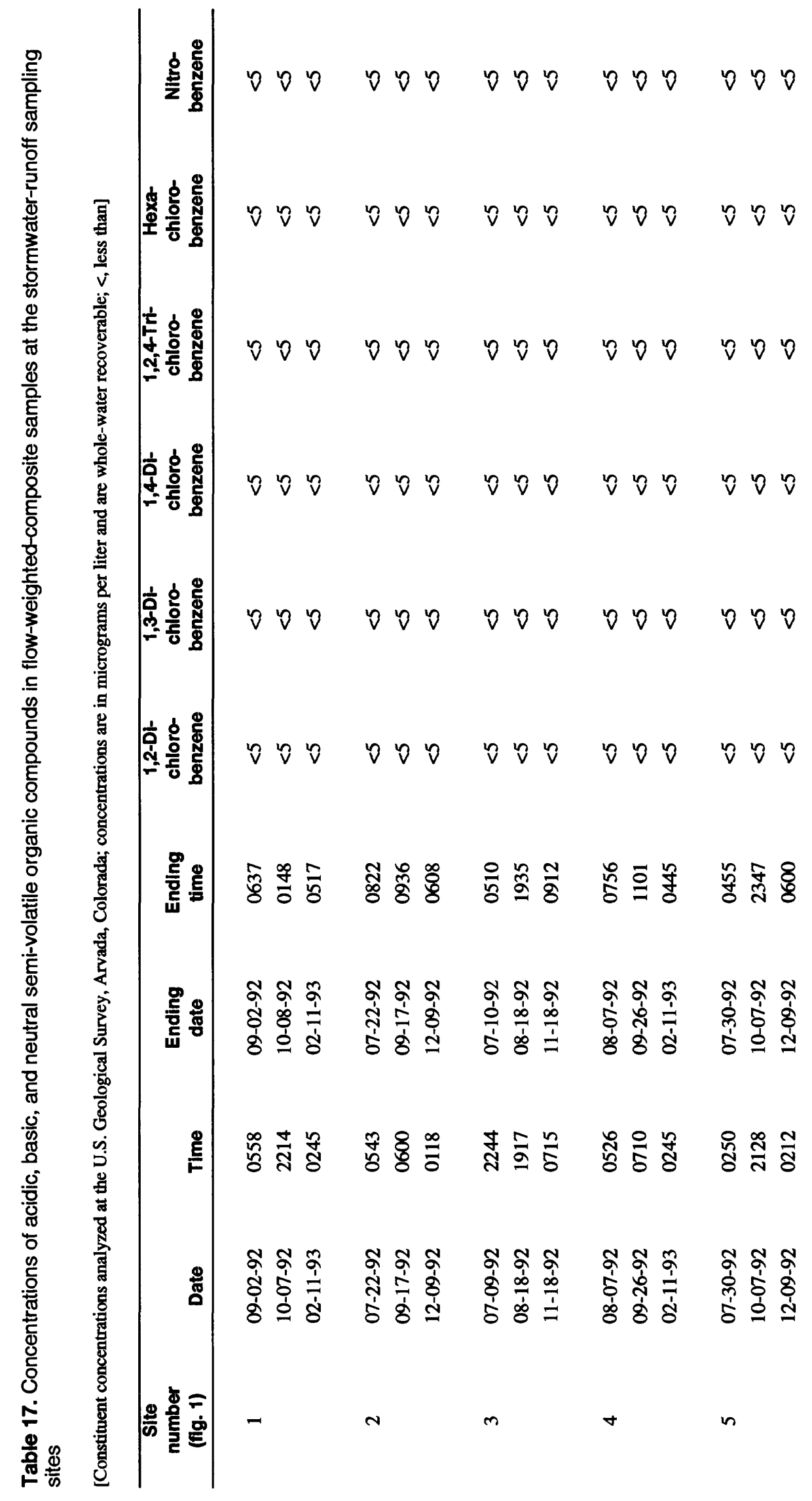




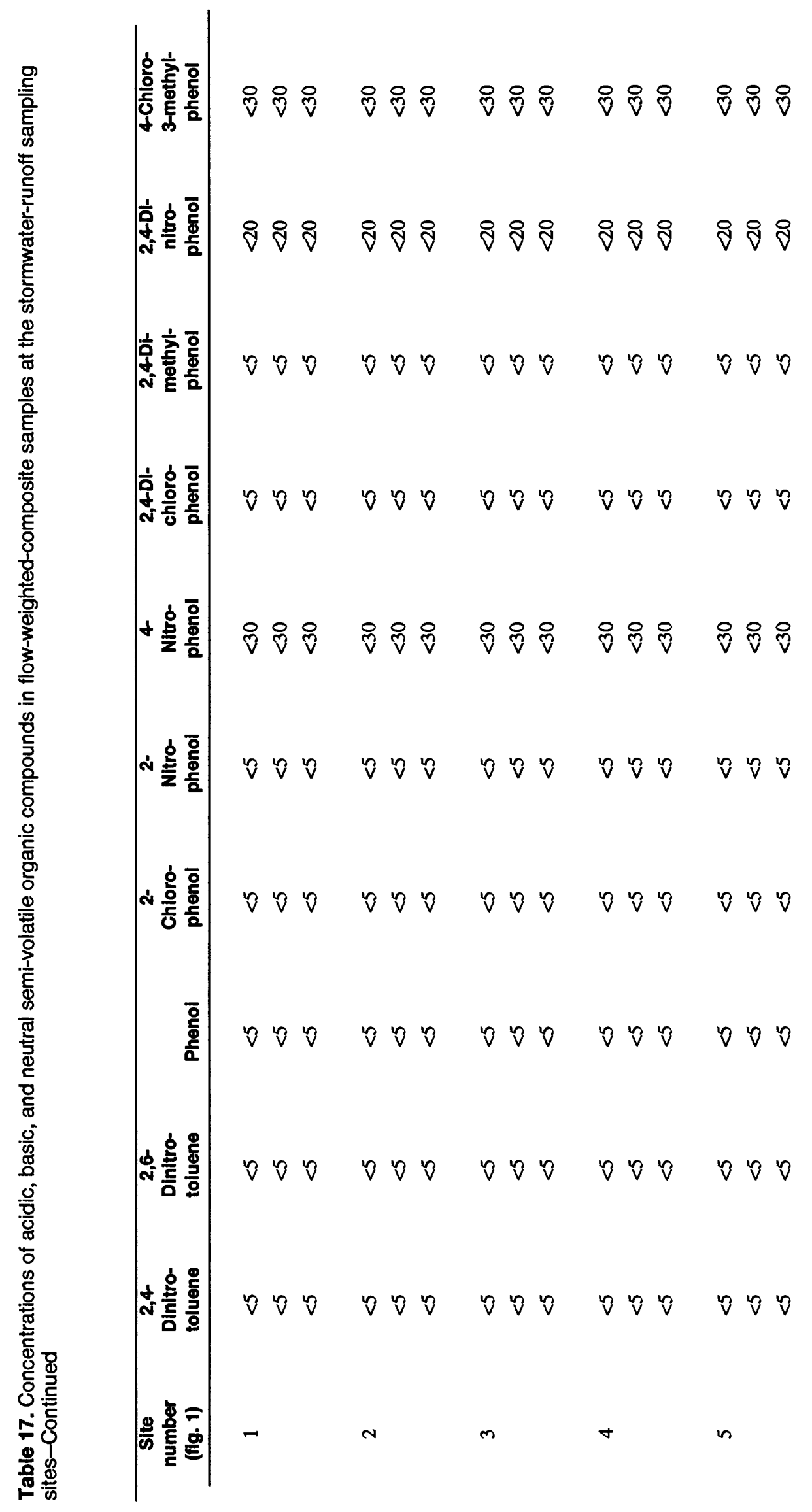




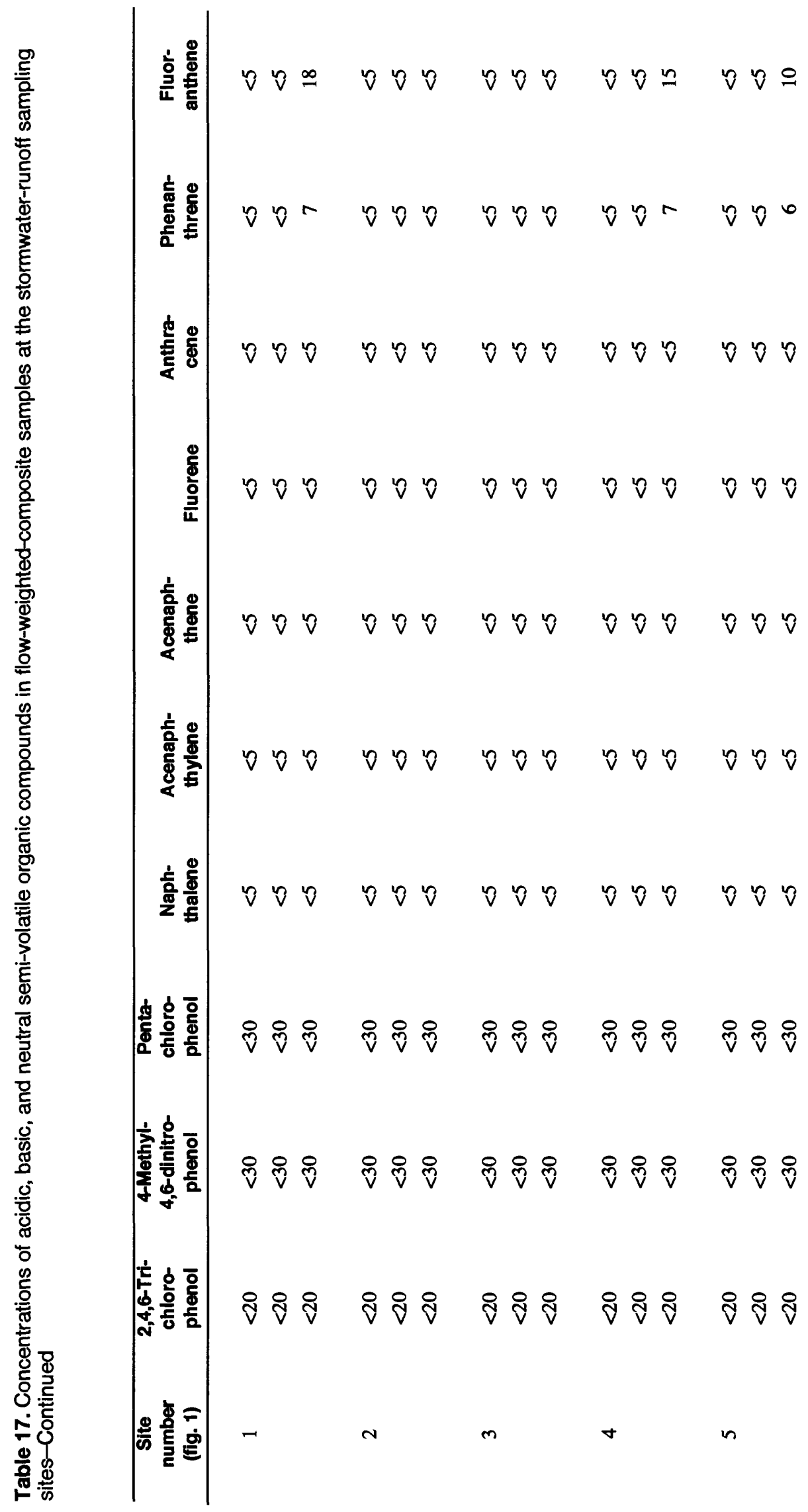




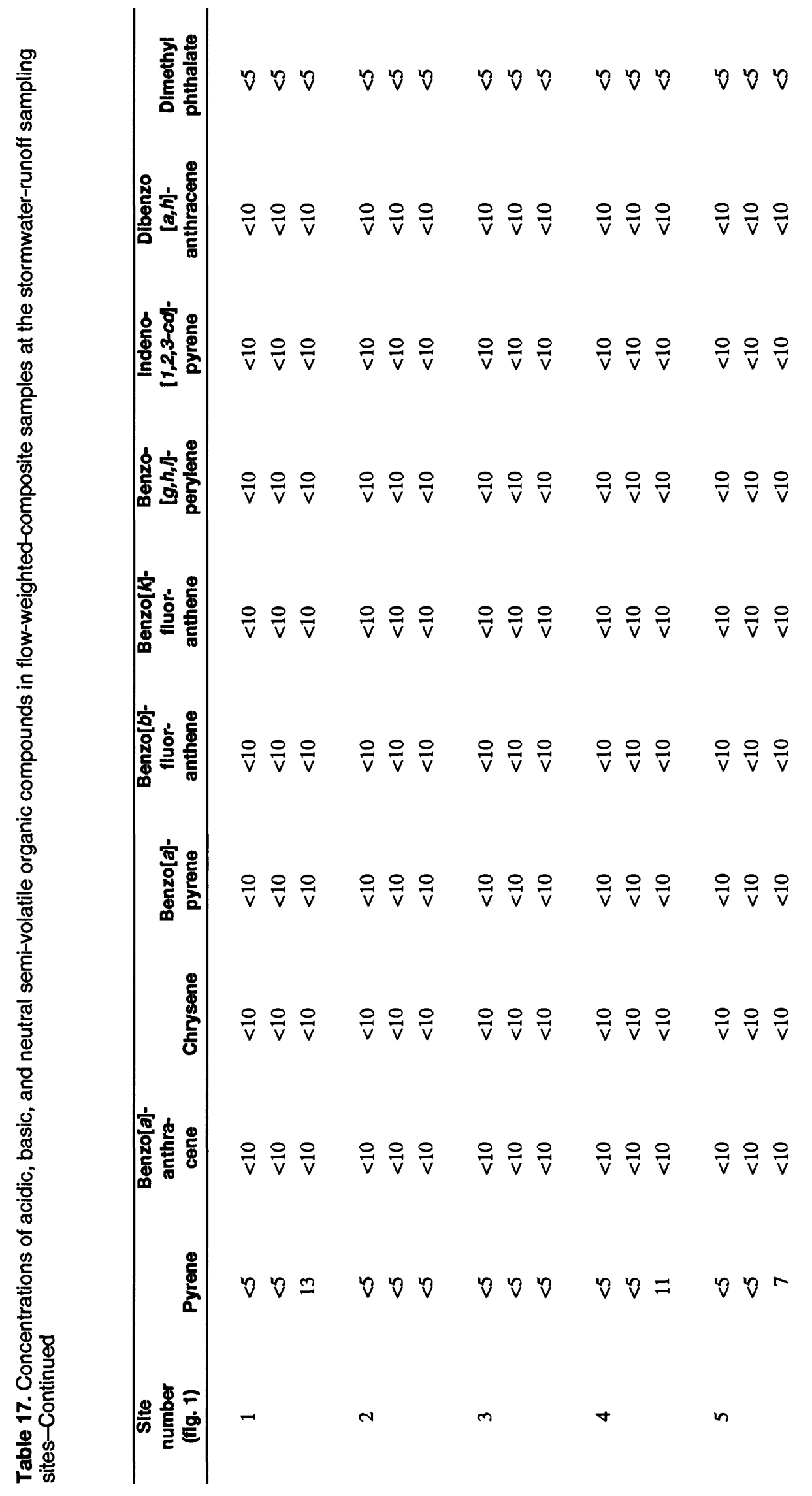




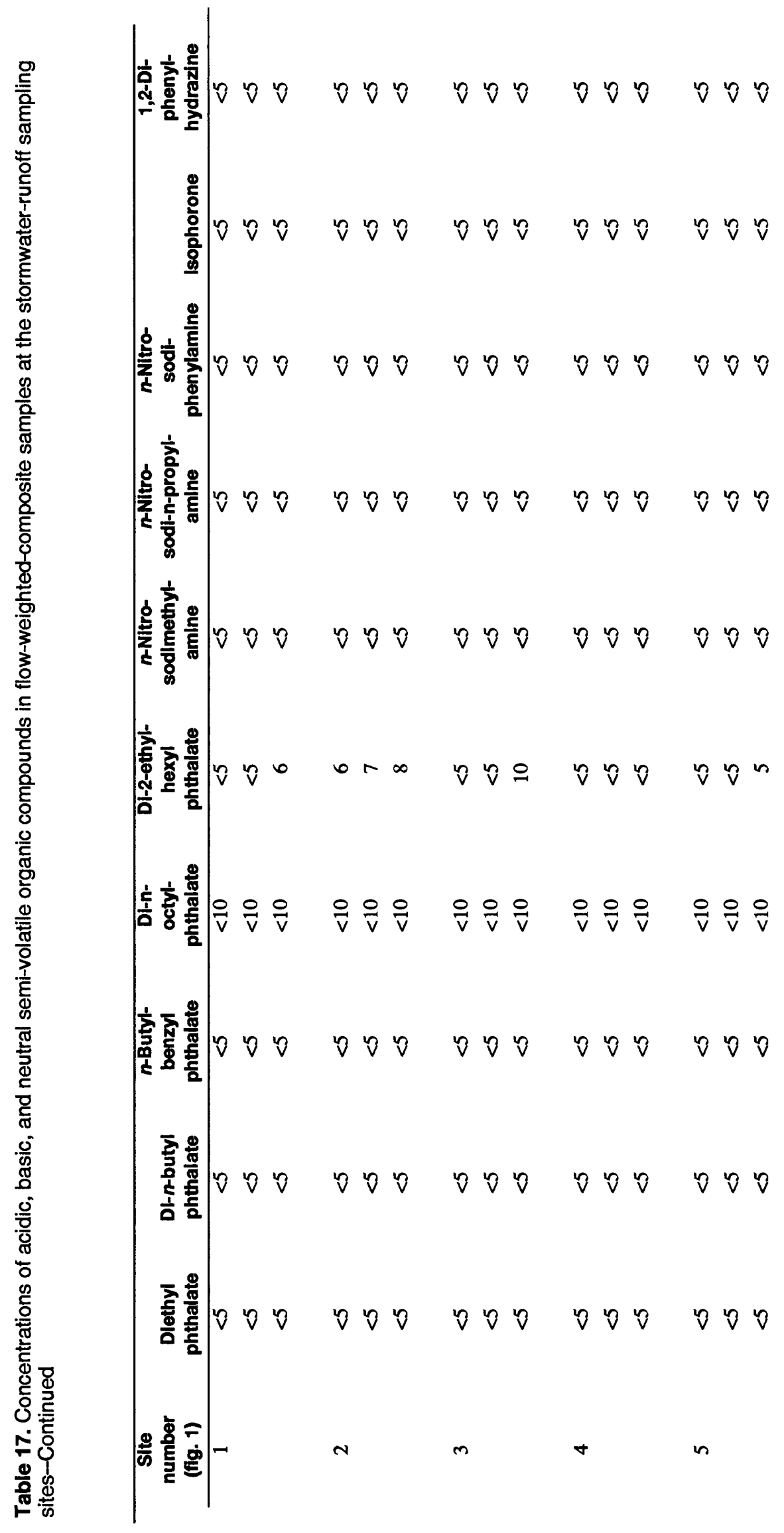




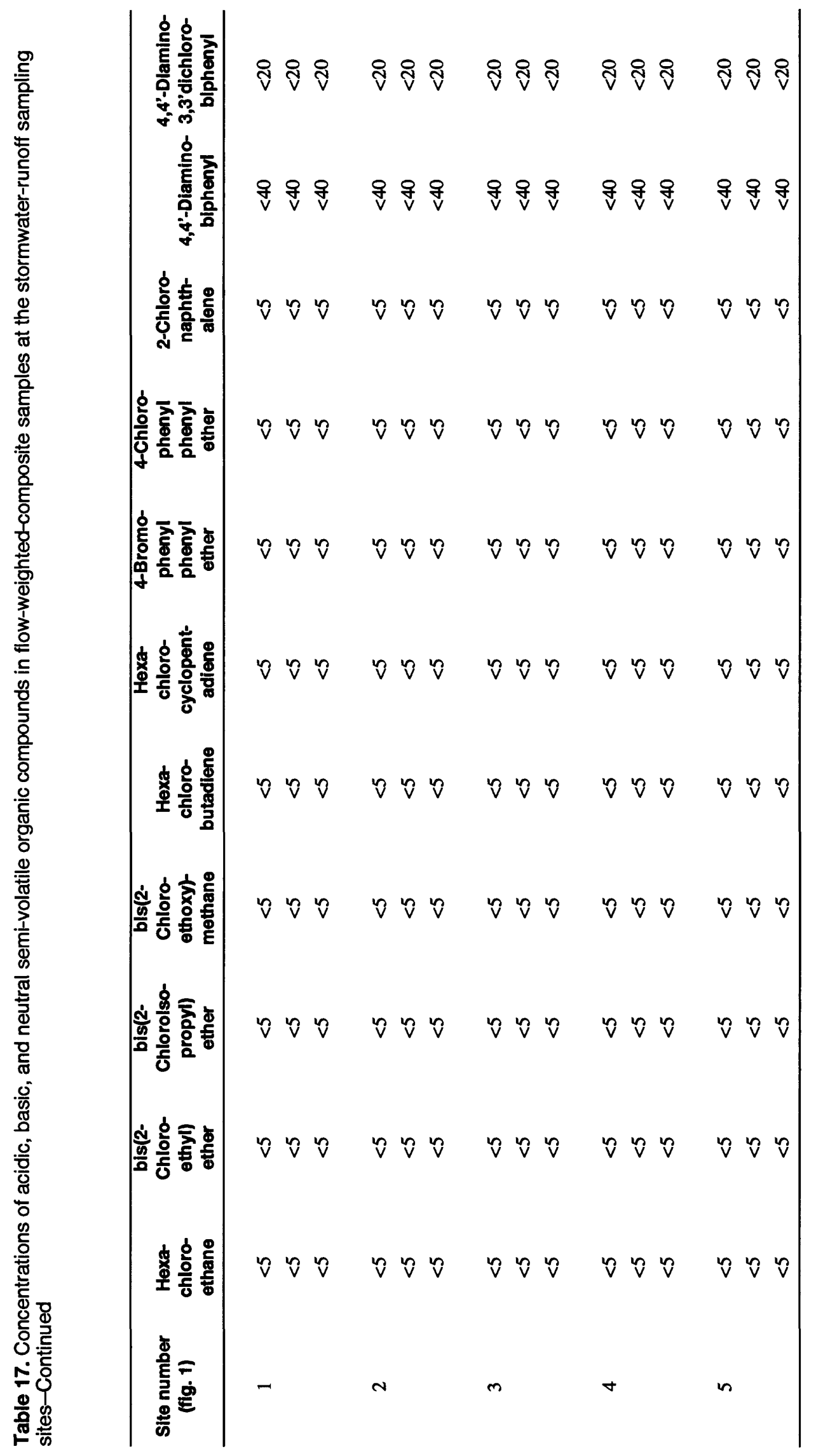


Table 18. Stormwater-runoff volume and constituent loads at site 1

[Simulated values were calculated using methods described by Driver and Tasker (1990); ${ }^{\circ} \mathrm{C}$, degrees Celsius; $>$, greater than; $\mathrm{CaCO}_{3}$, calcium carboate; ND, not detected; --, no data]

\begin{tabular}{|c|c|c|c|}
\hline \multirow[b]{2}{*}{ Constltuent } & \multicolumn{3}{|c|}{ Storm loads, In pounds } \\
\hline & 09-02-92 & $10-07-92$ & $02-11-93$ \\
\hline Volume, in cubic feet & 45,300 & 91,500 & 25,600 \\
\hline Volume, simulated, in cubic feet & 99,000 & 140,000 & 82,000 \\
\hline Chemical oxygen demand & 3,400 & 800 & 210 \\
\hline Chemical oxygen demand, simulated & 493 & 640 & 430 \\
\hline Biochemical oxygen demand, 5 -day at $20^{\circ} \mathrm{C}$ & $>1,800$ & 360 & 54 \\
\hline Calcium, dissolved & 51 & 150 & 120 \\
\hline Magnesium, dissolved & 4.8 & 16 & 13 \\
\hline Sodium, dissolved & 14 & 42 & 80 \\
\hline Potassium, dissolved & 9.0 & 28 & 5.6 \\
\hline Bicarbonate & 230 & 340 & 290 \\
\hline Alkalinity, total as $\mathrm{CaCO}_{3}$ & 190 & 280 & 240 \\
\hline Sulfate, dissolved & 37 & 120 & 120 \\
\hline Chloride, dissolved & 22 & 68 & 130 \\
\hline Dissolved solids, residue at $180^{\circ} \mathrm{C}$ & 286 & 817 & 609 \\
\hline Dissolved solids, simulated & 1,100 & 1,500 & 920 \\
\hline Suspended solids, residue at $105^{\circ} \mathrm{C}$ & 3,340 & 2,600 & 208 \\
\hline Suspended solids, simulated & 610 & 870 & 490 \\
\hline Nitrite plus nitrate as nitrogen, total & ND & 4.6 & -- \\
\hline Nitrite plus nitrate as nitrogen, dissolved & -- & -- & 1.3 \\
\hline Ammonia as nitrogen, total & ND & 1.6 & -- \\
\hline Ammonia as nitrogen, dissolved & -- & -- & 1.3 \\
\hline Ammonia plus organic nitrogen, total & 9.3 & 6.8 & 2.7 \\
\hline Ammonia plus organic nitrogen, simulated & 14 & 18 & 12 \\
\hline Organic nitrogen, total & 9.3 & 5.2 & - \\
\hline Nitrogen, total & 9.3 & 11.4 & 4.0 \\
\hline Nitrogen, simulated total & 18 & 23 & 15 \\
\hline Phosphorus, total & 3.7 & 3.4 & .40 \\
\hline Phosphorus, simulated total & 2.2 & 3.0 & 1.9 \\
\hline Phosphorus, dissolved & ND & 1.9 & .10 \\
\hline Phosphorus, simulated dissolved & .40 & .52 & .34 \\
\hline Arsenic, whole-water recoverable & .028 & .01 & .005 \\
\hline Cadmium, whole-water recoverable & .01 & .006 & .005 \\
\hline Cadmium, simulated total & .012 & .016 & .009 \\
\hline Chromium, whole-water recoverable & .28 & .03 & .033 \\
\hline Copper, whole-water recoverable & 27 & .30 & .030 \\
\hline Copper, simulated total & 17 & .19 & .15 \\
\hline Lead, whole-water recoverable & .74 & .34 & .094 \\
\hline Lead, simulated total & 66 & .84 & .57 \\
\hline Nickel, whole-water recoverable & .090 & .057 & .01 \\
\hline Zinc, whole-water recoverable & 2.4 & 1.4 & .38 \\
\hline Zinc, simulated total & 1.1 & 1.4 & 1.0 \\
\hline Organic carbon, total & 710 & 220 & 42 \\
\hline Chlordane, whole-water recoverable & .001 & .001 & .0002 \\
\hline cis-Chlordane, whole-water recoverable & .0003 & ND & ND \\
\hline trans-Chlordane, whole-water recoverable & .0003 & ND & ND \\
\hline Diazinon, whole-water recoverable & .003 & .001 & ND \\
\hline Dieldrin, whole-water recoverable & .0001 & ND & ND \\
\hline Benzene, whole-water recoverable & ND & .001 & ND \\
\hline p-Isopropyltoluene, whole-water recoverable & .0008 & ND & ND \\
\hline Naphthalene, whole-water recoverable & ND & ND & .0003 \\
\hline Di-2-ethylexyl phthalate, whole-water recoverable & ND & ND & .01 \\
\hline Fluoranthene,whole-water recoverable & ND & ND & .03 \\
\hline Phenanthrene, whole-water recoverable & ND & ND & .01 \\
\hline Pyrene, whole-water recoverable & ND & ND & .02 \\
\hline
\end{tabular}


Table 19. Stormwater-runoff volume and constituent loads at site 2

[Simulated values were calculated using methods described by Driver and Tasker (1990); ${ }^{\circ} \mathrm{C}$, degrees Celsius; >, greater than; $\mathrm{CaCO}_{3}$, calcium carbonate; ND, not detected; --, no data]

\begin{tabular}{|c|c|c|c|}
\hline \multirow[b]{2}{*}{ Constltuent } & \multicolumn{3}{|c|}{ Storm loads, In pounds } \\
\hline & $07-22-92$ & $09-17-92$ & $12-09-92$ \\
\hline Volume, in cubic feet & 13,200 & 21,600 & 11,800 \\
\hline Volume, simulated, in cubic feet & 48,400 & 38,800 & 21,600 \\
\hline Chemical oxygen demand & 157 & 129 & 354 \\
\hline Chemical oxygen demand, simulated & 323 & 272 & 173 \\
\hline Biochemical oxygen demand, 5-day at $20^{\circ} \mathrm{C}$ & $>37.6$ & 23.3 & 22 \\
\hline Calcium, dissolved & 16 & 31 & 35 \\
\hline Magnesium, dissolved & 1.4 & 2.2 & 4.27 \\
\hline Sodium, dissolved & 4.2 & 8 & 81 \\
\hline Potassium, dissolved & 1.5 & 2.8 & 1.8 \\
\hline Bicarbonate, & 49 & 92 & 96 \\
\hline Alkalinity, total as $\mathrm{CaCO}_{3}$ & 40 & 76 & 81 \\
\hline Sulfate, dissolved & 10.7 & 15 & 20 \\
\hline Chloride, dissolved & 7.1 & 15 & 120 \\
\hline Dissolved solids, residue at $180^{\circ} \mathrm{C}$ & 82 & 175 & 337 \\
\hline Dissolved solids, simulated & 241 & 196 & 112 \\
\hline Suspended solids, residue at $105^{\circ} \mathrm{C}$ & 166 & 206 & 79 \\
\hline Suspended solids, simulated & 493 & 388 & 205 \\
\hline Nitrite plus nitrate as nitrogen, total & .49 & 1.0 & .43 \\
\hline Ammonia as nitrogen, total & .21 & .20 & .25 \\
\hline Ammonia plus organic nitrogen, total & .5 & .8 & 1.0 \\
\hline Ammonia plus organic nitrogen, simulated total & 6.7 & 5.6 & 3.5 \\
\hline Organic nitrogen, total & .3 & 0.6 & .8 \\
\hline Nitrogen, total & 1.0 & 1.8 & 1.4 \\
\hline Nitrogen, simulated total & 6.9 & 5.7 & 3.5 \\
\hline Phosphorus, total & .22 & .45 & .23 \\
\hline Phosphorus, simulated total & 1.3 & 1.0 & .63 \\
\hline Phosphorus, dissolved & .09 & .22 & .07 \\
\hline Phosphorus, simulated dissolved & .20 & .16 & .10 \\
\hline Arsenic, whole-water recoverable & .002 & .004 & .001 \\
\hline Cadmium, whole-water recoverable & .0008 & .001 & .003 \\
\hline Cadmium, simulated total & .004 & .003 & .0019 \\
\hline Chromium, whole-water recoverable & ND & .007 & .006 \\
\hline Copper, whole-water recoverable & .0082 & .01 & .006 \\
\hline Copper, simulated total & .08 & .071 & .055 \\
\hline Lead, whole-water recoverable & .035 & .055 & .023 \\
\hline Lead, simulated total & .47 & .40 & .26 \\
\hline Nickel, whole-water recoverable & .006 & .01 & .004 \\
\hline Zinc, whole-water recoverable & .23 & .27 & .081 \\
\hline Zinc, simulated total & .50 & .42 & .28 \\
\hline Organic carbon, total & 54 & 38 & 19 \\
\hline Chlordane, whole-water recoverable & .00008 & ND & .00007 \\
\hline Diazinon, whole-water recoverable & .00008 & .0001 & ND \\
\hline Benzene, whole-water recoverable & .0002 & ND & ND \\
\hline n-Butylbenzene, whole-water recoverable & .0005 & ND & ND \\
\hline Ethylbenzene, whole-water recoverable & .0003 & ND & ND \\
\hline Mesitylene, whole-water recoverable & .0008 & ND & ND \\
\hline Naphthalene, whole-water recoverable & .0042 & ND & ND \\
\hline$n$-Propylbenzene, whole-water recoverable & .0002 & ND & ND \\
\hline Pseudocumene, whole-water recoverable & .004 & ND & ND \\
\hline Toluene, whole-water recoverable & .0011 & ND & ND \\
\hline Xylene, whole-water recoverable & .0019 & ND & ND \\
\hline Di-2-ethylexyl phthalate, whole-water recoverable & .005 & .009 & .006 \\
\hline
\end{tabular}


Table 20. Stormwater-runoff volume and constituent loads at site 3

[Simulated values were calculated using methods described by Driver and Tasker (1990); ${ }^{\circ} \mathrm{C}$, degrees Celsius; >, greater than; $\mathrm{CaCO}_{3}$, calcium carbonate; ND, not detected; --, no data]

\begin{tabular}{|c|c|c|c|}
\hline \multirow[b]{2}{*}{ Constltuent } & \multicolumn{3}{|c|}{ Storm loads, in pounds } \\
\hline & $07-09-92$ & $08-18-92$ & $11-18-92$ \\
\hline Volume, in cubic feet & 252,000 & 36,500 & 46,100 \\
\hline Volume, simulated in cubic feet & 150,000 & 45,000 & 29,500 \\
\hline Chemical oxygen demand & 570 & 3600 & 430 \\
\hline Chemical oxygen demand, simulated & 925 & 363 & 260 \\
\hline Biochemical oxygen demand, 5 -day at $20^{\circ} \mathrm{C}$ & 200 & $>500$ & 200 \\
\hline Calcium, dissolved & 130 & 48 & 52 \\
\hline Magnesium, dissolved & 8 & 2.5 & 3 \\
\hline Sodium, dissolved & 22 & 11 & 10 \\
\hline Potassium, dissolved & 24 & 7.0 & 3.5 \\
\hline Bicarbonate & 510 & 100 & -- \\
\hline Alkalinity, total as $\mathrm{CaCO}_{3}$ & 428 & 86 & -- \\
\hline Sulfate, dissolved & 60 & 43 & 23 \\
\hline Chloride, dissolved & 30 & 12 & 14 \\
\hline Dissolved solids, residue at $180^{\circ} \mathrm{C}$ & 540 & 280 & 220 \\
\hline Dissolved solids, simulated & 1,390 & 440 & 300 \\
\hline Suspended solids, residue at $105^{\circ} \mathrm{C}$ & 3,500 & 200 & 110 \\
\hline Suspended solids, simulated & 1,270 & 340 & 220 \\
\hline Nitrite plus nitrate as nitrogen, total & 6.0 & 2.3 & 2.6 \\
\hline Ammonia as nitrogen, total & 6.5 & 2.3 & 1.2 \\
\hline Ammonia plus organic nitrogen, total & 22 & 6.6 & 3.2 \\
\hline Ammonia plus organic nitrogen, simulated total & 18 & 7.0 & 5.0 \\
\hline Organic nitrogen, total & 16 & 4.3 & 2.0 \\
\hline Nitrogen, total & 28 & 8.9 & 5.8 \\
\hline Nitrogen, simulated total & 21 & 7.9 & 5.6 \\
\hline Phosphorus, total & 4.6 & 1.1 & .52 \\
\hline Phosphorus, simulated total & 3.5 & 1.2 & .83 \\
\hline Phosphorus, dissolved & .94 & .96 & .09 \\
\hline Phosphorus, simulated dissolved & .59 & .22 & .16 \\
\hline Arsenic, whole-water recoverable & .03 & .002 & .003 \\
\hline Cadmium, whole-water recoverable & .02 & .002 & ND \\
\hline Cadmium, simulated total & .01 & .003 & .002 \\
\hline Chromium, whole-water recoverable & .27 & .02 & -- \\
\hline Copper, whole-water recoverable & .29 & .043 & .03 \\
\hline Copper, simulated total & .20 & .12 & .099 \\
\hline Lead, whole-water recoverable & 1.4 & .089 & .058 \\
\hline Lead, simulated total & 1.5 & .62 & .46 \\
\hline Nickel, whole-water recoverable & .1 & .01 & .01 \\
\hline Zinc, whole-water recoverable & 3.6 & .66 & .32 \\
\hline Zinc, simulated total & 1.8 & .76 & .57 \\
\hline Organic carbon, total & 190 & 930 & 110 \\
\hline Diazinon, whole-water recoverable & .003 & .0002 & ND \\
\hline Ethylbenzene, whole-water recoverable & ND & .0007 & ND \\
\hline Mesitylene, whole-water recoverable & ND & .0009 & ND \\
\hline Naphthalene, whole-water recoverable & ND & .002 & ND \\
\hline$n$-Propylbenzene, whole-water recoverable & ND & .0005 & ND \\
\hline Pseudocumene, whole-water recoverable & ND & .0032 & ND \\
\hline Toluene, whole-water recoverable & .003 & .0009 & ND \\
\hline Xylene, whole-water recoverable & ND & .0041 & ND \\
\hline Di-2-ethylexyl phthalate, whole-water recoverable & ND & ND & .029 \\
\hline
\end{tabular}


Table 21. Stormwater-runoff volume and constituent loads at site 4

[Simulated values were calculated using methods described by Driver and Tasker (1990); ${ }^{\circ} \mathrm{C}$, degrees Celsius; $\mathrm{CaCO}_{3}$, calcium carbonate; $\mathrm{ND}$, not detected; --, no data]

\begin{tabular}{|c|c|c|c|}
\hline \multirow[b]{2}{*}{ Constltuent } & \multicolumn{3}{|c|}{ Storm loads, In pounds } \\
\hline & 08-07-92 & $09-26-92$ & $02-11-93$ \\
\hline Volume, in cubic feet & 97,700 & 38,400 & 23,200 \\
\hline Volume, simulated in cubic feet & 120,000 & 71,000 & 56,000 \\
\hline Chemical oxygen demand & 340 & 140 & 300 \\
\hline Chemical oxygen demand, simulated & 820 & 530 & 440 \\
\hline Biochemical oxygen demand, 5 -day at $20^{\circ} \mathrm{C}$ & 89 & -- & 64 \\
\hline Calcium, dissolved & 170 & 98 & 35 \\
\hline Magnesium, dissolved & 15 & 8.4 & 2.2 \\
\hline Sodium, dissolved & 51 & 31 & 28 \\
\hline Potassium, dissolved & 15 & 5.0 & 2.6 \\
\hline Bicarbonate & 470 & 210 & 130 \\
\hline Alkalinity, total as $\mathrm{CaCO}_{3}$ & 380 & 170 & 110 \\
\hline Sulfate, dissolved & 140 & 70 & 30 \\
\hline Chloride, dissolved & 110 & 53 & 38 \\
\hline Dissolved solids, residue at $180^{\circ} \mathrm{C}$ & 790 & 420 & 190 \\
\hline Dissolved solids, simulated & 1,300 & 760 & 600 \\
\hline Suspended solids, residue at $105^{\circ} \mathrm{C}$ & 3,300 & 210 & 110 \\
\hline Suspended solids, simulated & 950 & 520 & 400 \\
\hline Nitrite nitrogen, dissolved & -- & -- & .01 \\
\hline Nitrite plus nitrate as nitrogen, total & 5.7 & 3.1 & -- \\
\hline Nitrite plus nitrate as nitrogen, dissolved & -- & -- & 2.2 \\
\hline Ammonia as nitrogen, total & 2.1 & .70 & -- \\
\hline Ammonia as nitrogen, dissolved & -- & -- & .74 \\
\hline Ammonia plus organic nitrogen, total & 8.5 & 2 & 2.2 \\
\hline Ammonia plus organic nitrogen, simulated total & 16 & 10 & 8.5 \\
\hline Organic nitrogen, total & 6.7 & .98 & -- \\
\hline Nitrogen, total & 14.2 & 5 & 4.4 \\
\hline Nitrogen, simulated total & 19 & 12 & 9.9 \\
\hline Phosphorus, total & 3.7 & .48 & .41 \\
\hline Phosphorus, simulated total & 2.9 & 1.8 & 1.4 \\
\hline Phosphorus, dissolved & .92 & .2 & .1 \\
\hline Phosphorus, simulated dissolved & .50 & .32 & .26 \\
\hline Arsenic, whole-water recoverable & .02 & .007 & .003 \\
\hline Cadmium, whole-water recoverable & .01 & ND & .003 \\
\hline Cadmium, simulated total & .009 & .005 & .004 \\
\hline Chromium, whole-water recoverable & .05 & .005 & .035 \\
\hline Copper, whole-water recoverable & .79 & .074 & .025 \\
\hline Copper, simulated total & .20 & .15 & .14 \\
\hline Lead, whole-water recoverable & .61 & .062 & .16 \\
\hline Lead, simulated total & 1.2 & .79 & .66 \\
\hline Mercury, whole-water recoverable & .001 & ND & ND \\
\hline Nickel, whole-water recoverable & .073 & .007 & .01 \\
\hline Silver, whole-water recoverable & ND & .029 & ND \\
\hline Zinc, whole-water recoverable & 2.5 & .34 & .43 \\
\hline Zinc, simulated total & 1.6 & 1.1 & .90 \\
\hline Organic carbon, total & 150 & 34 & 43 \\
\hline Lindane, whole-water recoverable & ND & ND & .00004 \\
\hline$p, p^{\prime}$-DDT, whole-water recoverable & ND & ND & .0001 \\
\hline$p, p^{\prime}$-DDD, whole-water recoverable & ND & ND & .0001 \\
\hline Diazinon, whole-water recoverable & .001 & ND & ND \\
\hline PCB, Aroclor 1248 , whole-water recoverable & .015 & ND & ND \\
\hline Pseudocumene, whole-water recoverable & ND & .001 & ND \\
\hline Styrene, whole-water recoverable & ND & .0005 & ND \\
\hline Fluoranthene, whole-water recoverable & ND & ND & .022 \\
\hline Phenanthrene, whole-water recoverable & ND & ND & .01 \\
\hline Pyrene, whole-water recoverable & ND & ND & .016 \\
\hline
\end{tabular}


Table 22. Stormwater-runoff volume and constituent loads at site 5

[Simulated values were calculated using methods described by Driver and Tasker (1990); ${ }^{\circ} \mathrm{C}$, degrees Celsius; $<$, less than; $\mathrm{CaCO}_{3}$, calcium carbonate; ND, not detected; --, no data]

\begin{tabular}{|c|c|c|c|}
\hline \multirow[b]{2}{*}{ Constituent } & \multicolumn{3}{|c|}{ Storm loads, In pounds } \\
\hline & $07-30-92$ & $10-07-92$ & 12-09-92 \\
\hline Volume, in cubic feet & 12,800 & 19,800 & 10,200 \\
\hline Volume, simulated in cubic feet & 28,000 & 40,000 & 8,600 \\
\hline Chemical oxygen demand & 110 & 330 & 44 \\
\hline Chemical oxygen demand, simulated & 130 & 170 & 50 \\
\hline Biochemical oxygen demand, 5 -day at $20^{\circ} \mathrm{C}$ & $<13$ & 120 & 65 \\
\hline Calcium, dissolved & 77 & 66 & 89 \\
\hline Magnesium, dissolved & 2.7 & 3.1 & 3.9 \\
\hline Sodium, dissolved & 2,300 & 2,000 & 3,700 \\
\hline Potassium, dissolved & 2.3 & .5 & 2.3 \\
\hline Bicarbonate & 200 & 47 & 60 \\
\hline Alkalinity, total as $\mathrm{CaCO}_{3}$ & 160 & 38 & 51 \\
\hline Sulfate, dissolved & 9.7 & 140 & 270 \\
\hline Chloride, dissolved & 3,600 & 2,600 & 5,200 \\
\hline Dissolved solids, residue at $180^{\circ} \mathrm{C}$ & 6,800 & 5,600 & 9,400 \\
\hline Dissolved solids, simulated & 87 & 120 & 28 \\
\hline Suspended solids, residue at $105^{\circ} \mathrm{C}$ & 970 & 440 & 390 \\
\hline Suspended solids, simulated & 316 & 470 & 87 \\
\hline Nitrite as nitrogen, total & ND & .02 & .006 \\
\hline Nitrite plus nitrate as nitrogen, total & .40 & .52 & .27 \\
\hline Ammonia as nitrogen, total & .27 & .46 & .25 \\
\hline Ammonia plus organic nitrogen, total & .5 & 1.1 & .1 \\
\hline Ammonia plus organic nitrogen, simulated total & 3.8 & 5.1 & 1.5 \\
\hline Organic nitrogen, total & .2 & .6 & ND \\
\hline Nitrogen, total & .9 & 1.6 & .4 \\
\hline Nitrogen, simulated total & 3.2 & 4.4 & 1.2 \\
\hline Phosphorus, total & .52 & .62 & .08 \\
\hline Phosphorus, simulated total & .85 & 1.2 & .30 \\
\hline Phosphorus, dissolved & .02 & .12 & ND \\
\hline Phosphorus, simulated dissolved & .12 & .17 & .048 \\
\hline Cyanide, total & .008 & ND & .006 \\
\hline Arsenic, whole-water recoverable & .005 & .002 & .002 \\
\hline Cadmium, whole-water recoverable & .032 & .19 & .014 \\
\hline Cadmium, simulated total & .0013 & .002 & .0004 \\
\hline Chromium, whole-water recoverable & .019 & .017 & .026 \\
\hline Copper, whole-water recoverable & .036 & .027 & .015 \\
\hline Copper, simulated total & .052 & .061 & .030 \\
\hline Lead, whole-water recoverable & .64 & .36 & .32 \\
\hline Lead, simulated total & .19 & .25 & .08 \\
\hline Mercury, whole-water recoverable & .0002 & ND & .00006 \\
\hline Nickel, whole-water recoverable & .030 & .020 & .015 \\
\hline Zinc, whole-water recoverable & 5.0 & 2.7 & 2.3 \\
\hline Zinc, simulated total & .34 & .43 & .15 \\
\hline Organic carbon, total & 18 & 84 & -- \\
\hline Benzene, whole-water recoverable & ND & .0002 & ND \\
\hline Dichlorodifluoromethane, whole-water recoverable & ND & .0004 & ND \\
\hline Dichloromethane, whole-water recoverable & ND & .0002 & ND \\
\hline Di-2-ethylexyl phthalate, whole-water recoverable & ND & ND & .003 \\
\hline Fluoranthene, whole-water recoverable & ND & ND & .006 \\
\hline Phenanthrene, whole-water recoverable & ND & ND & .004 \\
\hline Pyrene, whole-water recoverable & ND & ND & .004 \\
\hline
\end{tabular}

